\title{
LIFE CYCLE ASSESSMENTS (LCAS) OF PYROLYSIS-BASED GASOLINE AND DIESEL FROM DIFFERENT REGIONAL FEEDSTOCKS: CORN STOVER, SWITCHGRASS, SUGAR CANE BAGASSE, WASTE WOOD, GUINEA GRASS, ALGAE, AND ALBIZIA
}

Matthew J. Mihalek

Michigan Technological University

Follow this and additional works at: https://digitalcommons.mtu.edu/etds

Part of the Chemical Engineering Commons

Copyright 2014 Matthew J. Mihalek

Recommended Citation

Mihalek, Matthew J., "LIFE CYCLE ASSESSMENTS (LCAs) OF PYROLYSIS-BASED GASOLINE AND DIESEL FROM DIFFERENT REGIONAL FEEDSTOCKS: CORN STOVER, SWITCHGRASS, SUGAR CANE BAGASSE, WASTE WOOD, GUINEA GRASS, ALGAE, AND ALBIZIA", Master's Thesis, Michigan Technological University, 2014.

https://doi.org/10.37099/mtu.dc.etds/825

Follow this and additional works at: https://digitalcommons.mtu.edu/etds

Part of the Chemical Engineering Commons 
LIFE CYCLE ASSESSMENTS (LCAs) OF PYROLYSIS-BASED GASOLINE AND DIESEL FROM DIFFERENT REGIONAL FEEDSTOCKS: CORN STOVER, SWITCHGRASS, SUGAR CANE BAGASSE, WASTE WOOD, GUINEA GRASS, ALGAE, AND ALBIZIA

By

Matthew J. Mihalek

\begin{abstract}
A THESIS
Submitted in partial fulfillment of the requirements for the degree of MASTER OF SCIENCE

In Chemical Engineering
\end{abstract}

MICHIGAN TECHNOLOGICAL UNIVERSITY

2014

(C) 2014 Matthew J. Mihalek 
This thesis has been approved in partial fulfillment of the requirements for the Degree of MASTER OF SCIENCE in Chemical Engineering

Department of Chemical Engineering

Thesis Advisor: Dr. David Shonnard

Committee Member: $\quad$ Dr. Wen Zhou

Committee Member: $\quad$ Dr. Gregory Graman

Department Chair: Komar Kawatra 


\section{Table of Contents}

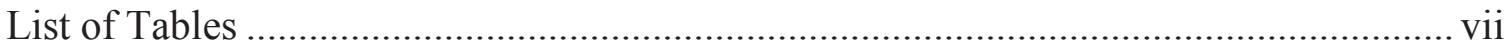

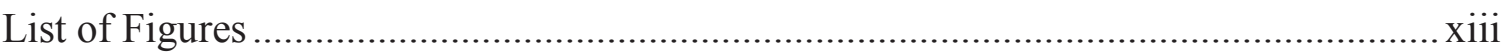

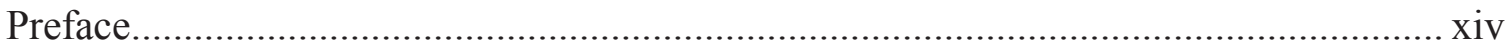

Abbreviation Definition List.............................................................................. $\mathrm{xV}$

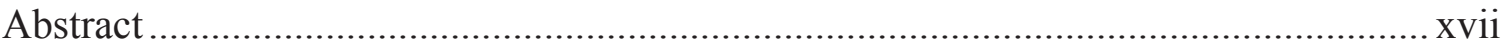

\section{Chapter 1: Introduction to Pyrolysis Based Liquid Hydrocarbon}

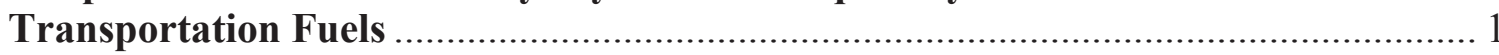

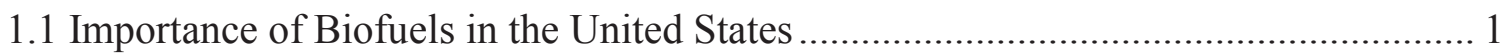

1.1.1Energy Security/Reduction in Imports..................................................................... 1

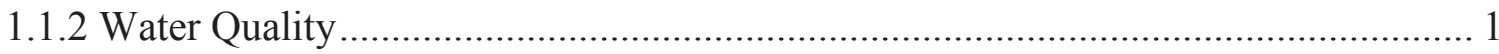

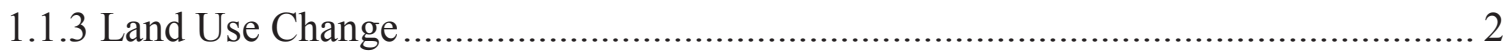

1.1.4 Other Factors Affecting GHG Emissions of Biofuels ............................................ 3

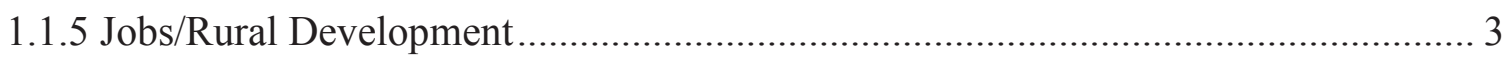

1.2 Background on Rapid Thermal Processing of Biofuels............................................... 4

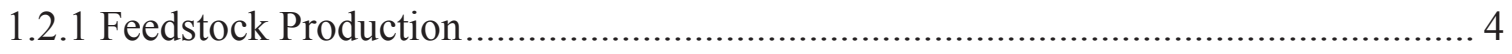

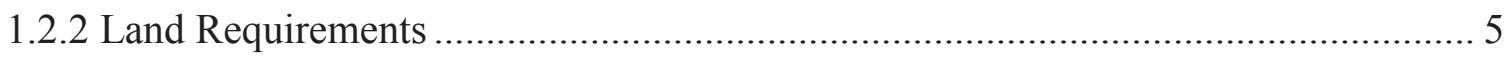

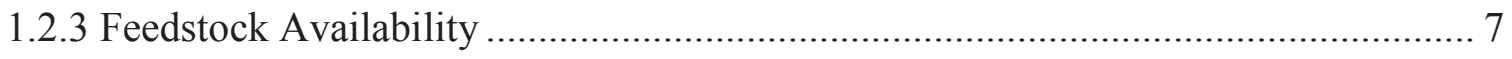

1.2.4 Integrated Biorefinery for Production of Biofuel .................................................. 8

1.2.5 Rapid Thermal Processing (Fast Pyrolysis) …………............................................. 9

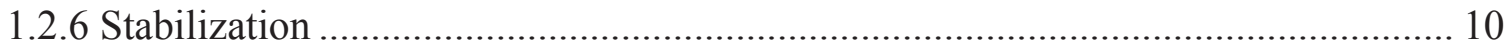

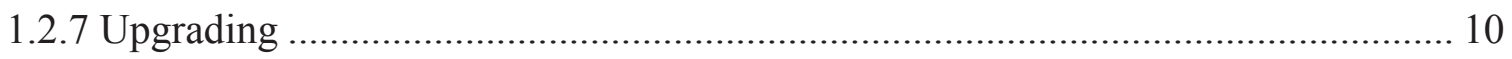




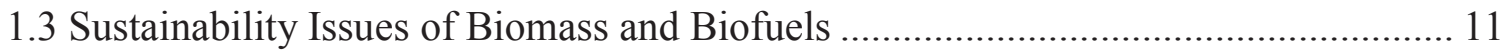

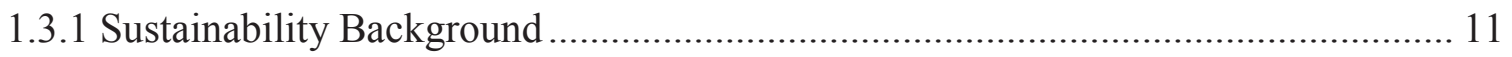

1.3.2 Switchgrass/Guinea Grass Sustainability Issues.......................................... 12

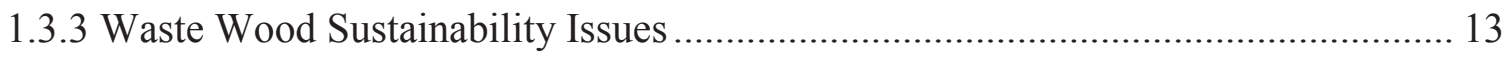

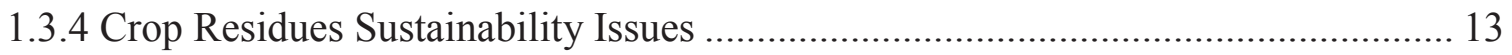

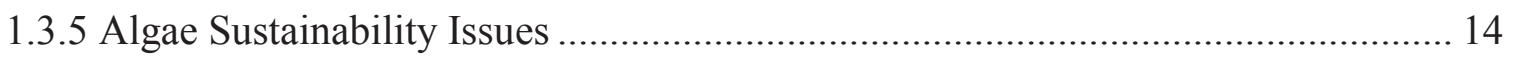

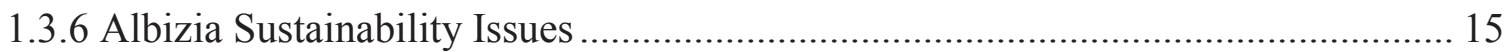

1.4 A Review of LCA of Pyrolysis-Based Biofuels and Bioenergy .............................. 15

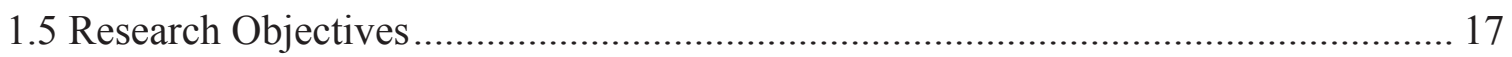

Chapter 2: Life Cycle Assessment: Background and Assumptions ........................ 18

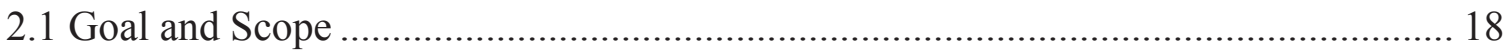

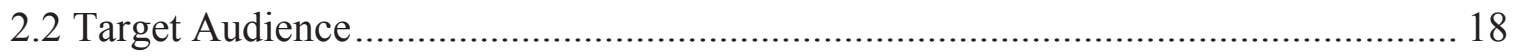

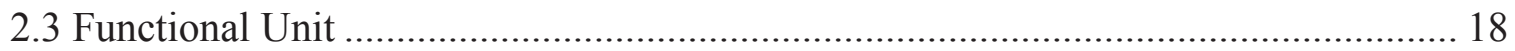

2.4 System Boundaries and Description of Product System...................................... 19

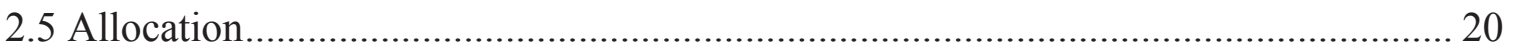

Chapter 3: Inputs and Results for Feedstock Production .................................... 22

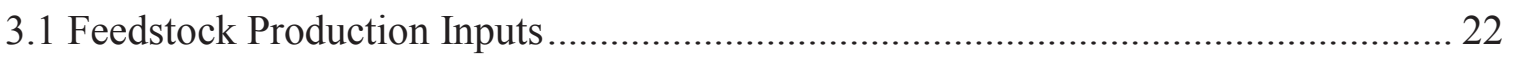

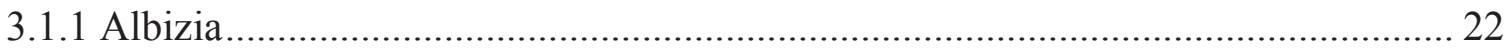

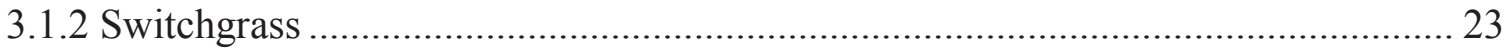

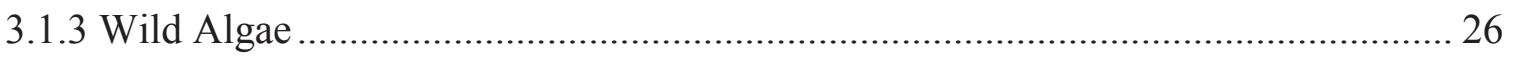

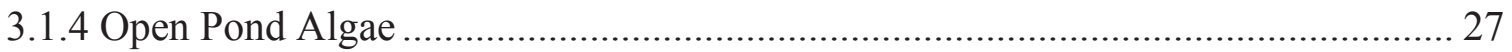

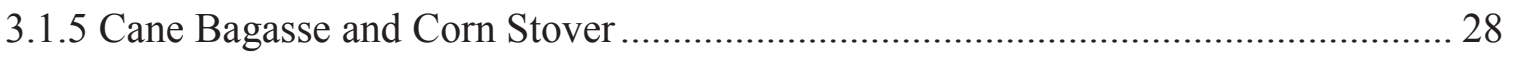

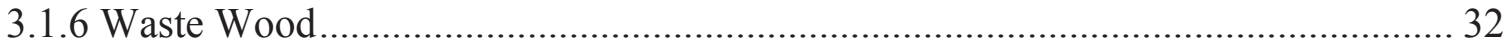


3.2 Life Cycle Impact Assessment......................................................................... 35

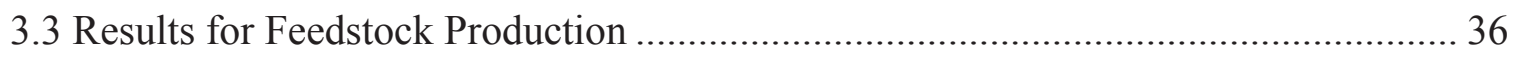

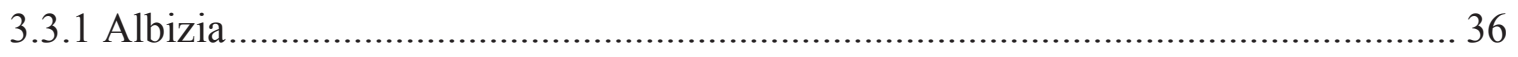

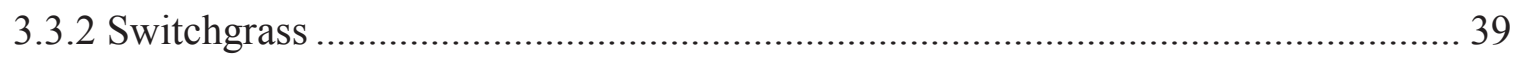

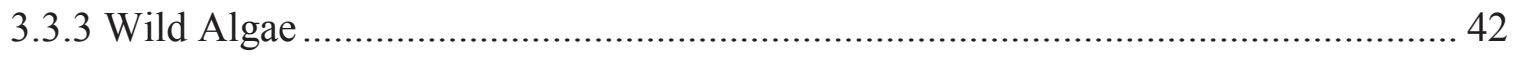

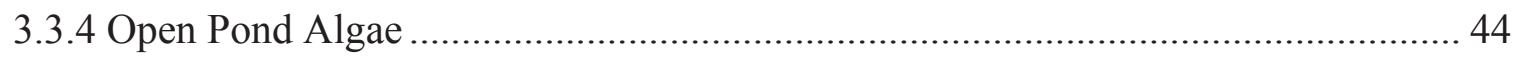

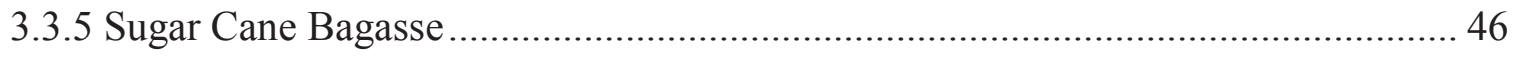

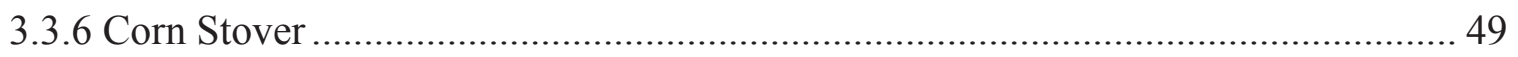

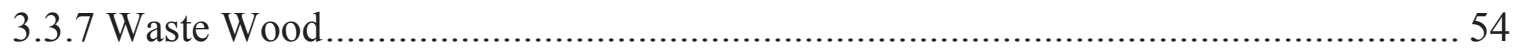

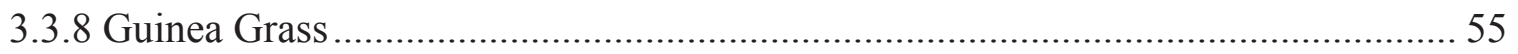

Chapter 4 Inputs and Results for Stabilized PyOil Production .............................. 59

4.1 Inputs for Pretreatment, Pyrolysis, and Stabilization......................................... 59

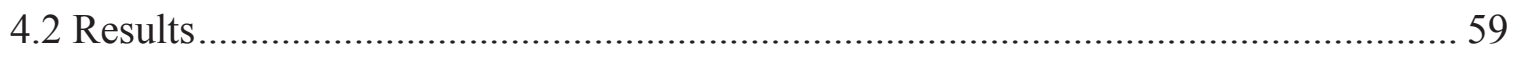

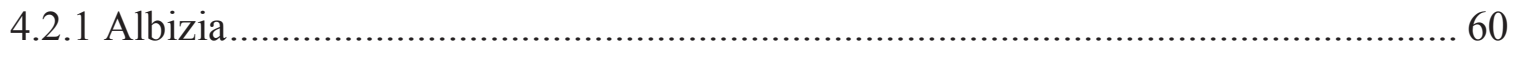

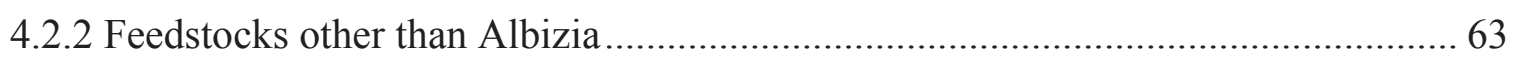

Chapter 5: Inputs and Results for Hydrocarbon Biofuel Production ...................... 69

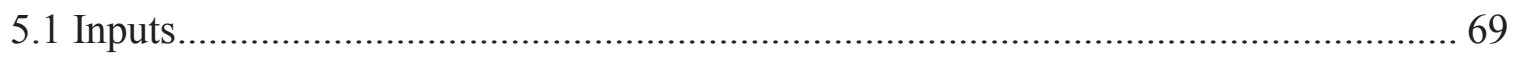

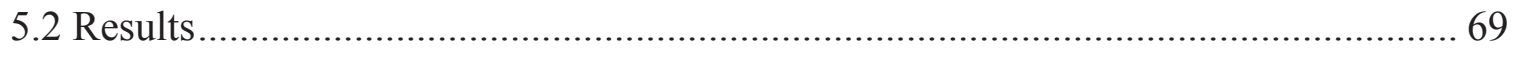

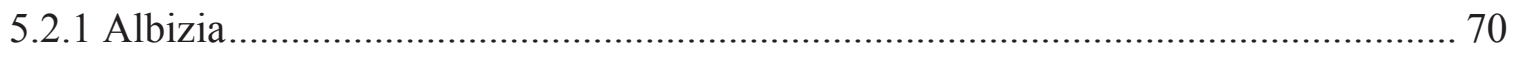

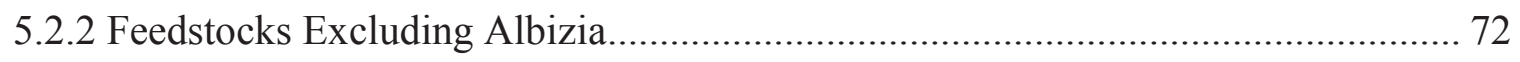




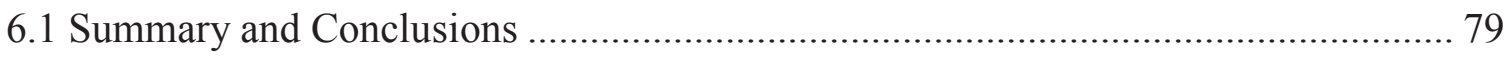

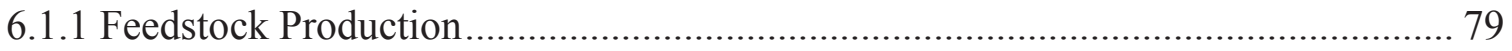

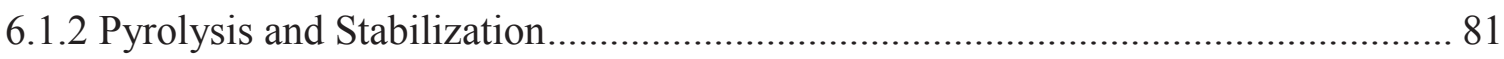

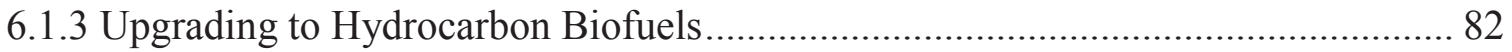

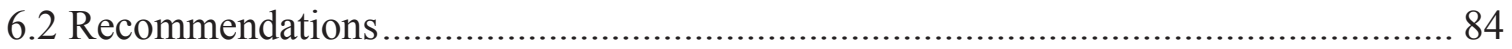

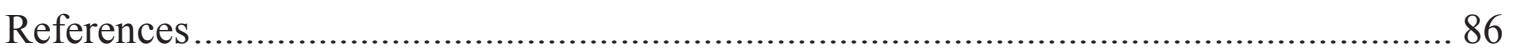

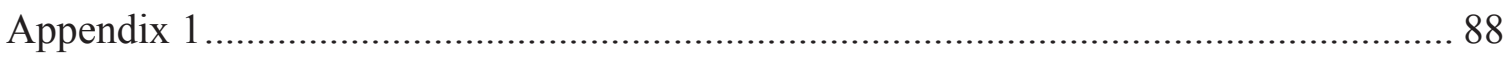

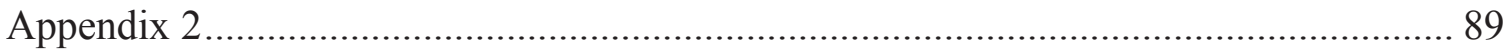

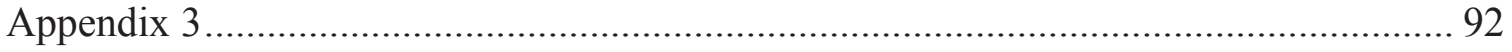

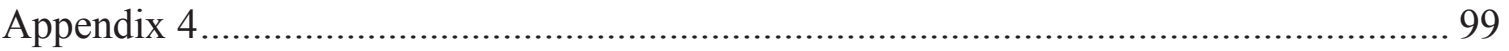

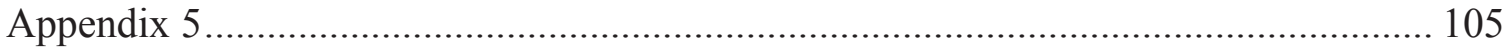

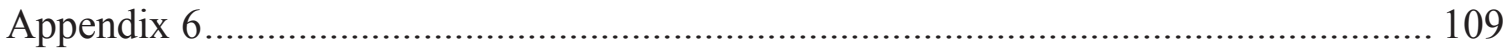




\section{List of Tables}

Table 1.1: Land and Energy Requirements for a 2,800 BDMTD for each Feedstock ....... 6

Table 1.2: Yield and LHV references for each feedstock ............................................... 7

Table 1.3: The amount of feedstock that is available annually and can be sustainably harvested in million dry metric tons per year (MDT) (U.S. Department of Energy 2011) 7 Table 2.1: EAFs for each feedstock at each stage. Calculations are shown for each EAF in the Appendix 2.

Table 3.1: Inventory data from the report by (Stratton et al. 2010) for open pond algae cultivation, harvesting, drying and transport with a basis of one dry metric ton algae .... 28 Table 3.2: Inputs for corn stover as a waste and also for low ash corn stover with a basis of one dry metric ton of feedstock (Morey et al. 2010)

Table 3.3: Inputs for the cane bagasse as a waste with a basis of one dry metric ton of feedstock 32

Table 3.4: GHG emissions for albizia production in Hawaii with a basis of one MT of dry albizia (kg CO2 equivalent (eq) emissions). 37 Table 3.5: Cumulative energy demand of albizia production in Hawaii with a basis of one MJ of albizia 38

Table 3.6: Fossil energy demand of albizia production in Hawaii with a basis of one MJ of albizia. 38

Table 3.7: Switchgrass GHG emissions for three scenarios at different transportation distances $(15,25$, and 50 miles) with a basis of one dry metric ton and comparison to literature (Cherubini and Jungmeier 2010).

Table 3.8: Total GHG emissions for Switchgrass including nitrogen fertilizer for all locations and nitrogen balance (\#9) and at varying transportation distances with a basis of one dry metric ton. (kg CO2 eq emissions) .....

Table 3.9: Comparing an average cumulative energy demand of switchgrass with inputs from Ceres and literature (Cherubini and Jungmeier 2010) with a basis of one MJ of switchgrass.

Table 3.10: Average fossil energy demand of switchgrass with inputs from Ceres with a basis of one MT and MJ of switchgrass.

Table 3.11: Comparison of GHG emissions with different electricity derived energies with units of $\mathrm{kg}$ of CO2 eq. per dry metric ton of algae and an algae density of $300 \mathrm{~g} / \mathrm{m} 3$.

Table 3.12: Cumulative energy demand for various types of derived electricity in MJ eq. per MJ of algae.

Table 3.13: Fossil energy demand for U.S. mix electricity scenario with a basis of one MJ

Table 3.14: GHG emissions associated with the production of open pond algae with a basis of one dry MT of algae.

Table 3.15: CED for open pond algae production assuming solar drying with a basis of one dry MT of algae.....

Table 3.16: FED for open pond algae production with a basis of one dry MT of algae .. 46 
Table 3.17: GHG emissions of sugar cane ethanol, comparing CARB results to the EPA

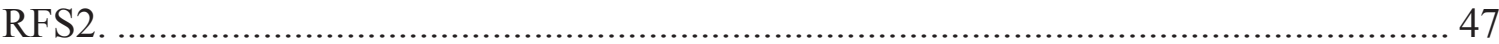

Table 3.18: GHG emissions of sugar cane bagasse when considered a waste product in $\mathrm{kg}$ $\mathrm{CO} 2 \mathrm{eq} / \mathrm{metric}$ ton dry bagasse ........................................................................ 48

Table 3.19: CED for sugarcane bagasse when considering bagasse as a waste product with a basis of one MJ of sugarcane bagasse........................................................... 49

Table 3.20: FED for sugarcane bagasse when considered a waste with a basis of one MJ of bagasse

Table 3.21: GHG emissions of corn stover, comparing SimaPro simulation and CARB

results

Table 3.22: GHG emissions of corn stover when considered a waste product in kg CO2

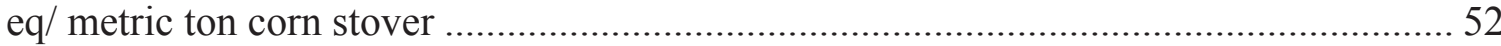

Table 3.23: CED for corn stover when considering stover as a waste product with a basis of one MJ of corn stover. 53 Table 3.24: FED for corn stover when considered a waste with a basis of one MJ of corn stover. 53

Table 3.25: Waste wood process stages and their corresponding GHG emissions with a basis of one dry metric ton.

Table 3.26: Cumulative energy demand of the waste wood process with a basis of one MJ

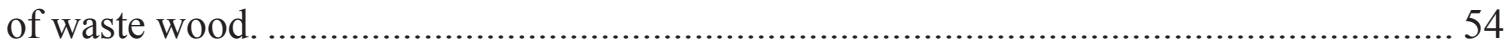

Table 3.27: FED for waste wood process with a basis of one MJ of waste wood............ 55 Table 3.28: Guinea grass process stages assuming managed land and their corresponding GHG emissions with a basis of one dry metric ton 56

Table 3.29: Guinea grass process stages assuming unmanaged land and their corresponding GHG emissions with a basis of one dry metric ton.... 56 Table 3.30: Average cumulative energy demand of the land preparation scenarios for guinea grass on managed lands with a basis of one MJ

Table 3.31: FED for guinea grass in Hawaii on managed land with a basis of one MJ of guinea grass.

Table 4.1: GHG emissions (CO2 eq.) for stabilized pyrolysis oil derived from albizia using both displacement and energy allocation with functional units of metric tons of stabilized pyrolysis oil and MJ of stabilized pyrolysis oil

Table 4.2: CED for stabilized pyrolysis oil derived from albizia using displacement allocation with a functional unit of one MJ of stabilized pyrolysis oil

Table 4.3: FED for stabilized pyrolysis oil derived from albizia using displacement allocation with a functional unit of one $\mathrm{MJ}$ of stabilized pyrolysis oil....

Table 4.4A: GHG emissions (CO2 eq.) for stabilized pyrolysis oil using displacement allocation with a functional unit of one MJ of stabilized pyrolysis oil....

Table 4.4B: Continuation of GHG emissions for stabilized pyrolysis oil using displacement allocation with a functional unit of one MJ of stabilized pyrolysis oil...... 65 Table 4.5A: CED for stabilized pyrolysis oil using displacement allocation with a functional unit of one MJ of stabilized pyrolysis oil ....

Table 4.5B: Continuation of CED for stabilized pyrolysis oil using displacement allocation with a functional unit of one MJ of stabilized pyrolysis oil 
Table 4.6A: FED for stabilized pyrolysis oil using displacement allocation with a functional unit of one $\mathrm{MJ}$ of stabilized pyrolysis oil

Table 4.6B: Continuation of FED for stabilized pyrolysis oil using displacement allocation with a functional unit of one MJ of stabilized pyrolysis oil....

Table 5.1: GHG emissions (CO2 eq.) for biofuel derived from albizia for both

displacement (Dis) and energy allocation (Spatari et al.) with two functional units of

metric tons of biofuel and MJ of biofuel.

Table 5.2: CED for biofuel derived from albizia using displacement allocation with a

functional unit of one MJ of biofuel

Table 5.3: FED for biofuel derived from albizia using displacement allocation with a

functional unit of one $\mathrm{MJ}$ of biofuel

Table 5.4A: GHG emissions (g CO2 eq/MJ) for upgraded pyrolysis oil using

displacement allocation with a functional unit of one MJ of upgraded pyrolysis oil ....... 73

Table 5.4B: GHG emissions (g CO2 eq/MJ) continued for upgraded pyrolysis oil using displacement allocation with a functional unit of one MJ of upgraded pyrolysis oil ....... 74

Table 5.5A: CED for upgraded pyrolysis oil using displacement allocation with a

functional unit of one MJ of upgraded pyrolysis oil.... 75

Table 5.5B: CED (continued) for upgraded pyrolysis oil using displacement allocation with a functional unit of one MJ of upgraded pyrolysis oil ........................................ 76

Table 5.6A: FED for upgraded pyrolysis oil using displacement allocation with a

functional unit of one $\mathrm{MJ}$ of upgraded pyrolysis oil.... 77

Table 5.6B: FED continued for upgraded pyrolysis oil using displacement allocation with a functional unit of one MJ of upgraded pyrolysis oil ............................................. 77

Table A2.1: EAF of each feedstock for pyrolysis, stabilization, and upgrading............. 89 Table A3.1: Albizia inputs mostly from the UP Survey and some from Grays Harbor (see Table A3.6) with a basis of one dry metric ton.

Table A3.2: Switchgrass inputs for three scenarios (SimaPro, Ceres, and Literature) at different transportation distances $(15,25$, and 50 miles) from Ceres and inputs from literature with a basis of one dry metric ton

Table A3.3: Nitrogen fertilizer related inputs for switchgrass at several different location scenarios with units of $\mathrm{kg}$ per one dry metric ton.

Table A3.4: Average annual CO2 Sequestration for switchgrass at several locations (from Ceres)

Table A3.5: Inventory data for algae cultivation, harvesting, and transport for Aquaflow

Bionomic Corporation with a basis of one dry metric ton and an algae density of 300

$\mathrm{g} / \mathrm{m} 3$. (C.D. = Confidential Data)

Table A3.6: Waste wood inputs with a basis of one dry metric ton (C.D. $=$ Confidential

Data).

Table A3.7: Guinea grass inputs for two scenarios with different land preparation requirements and a scenario on unmanaged land with a basis of one dry metric ton (C.D.

$=$ Confidential Data) 97

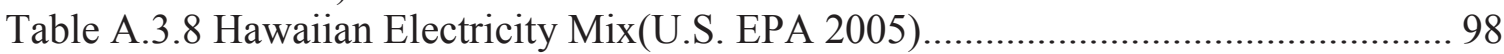

Table A4.1: Inputs for each feedstock for pretreatment and pyrolysis .......................... 99

Table A4.1 continued. 100 
Table A4.2: Inputs for each feedstock for stabilization.......................................... 101

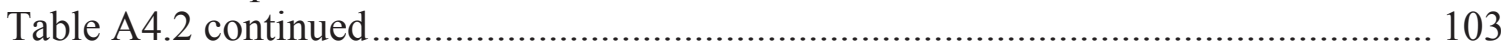

Table A5.1a: Upgrading inputs for all feedstocks. $\mathrm{HC}=$ hydrocarbon, $\mathrm{CW}=$ cooling water, $\mathrm{BFW}=$ boiler feed water, Demin.=demineralized, $\mathrm{HP}=$ high pressure .......................... 105 Table A5.1b: Upgrading inputs for all feedstock. $\mathrm{HC}=$ hydrocarbon, $\mathrm{CW}=$ cooling water,

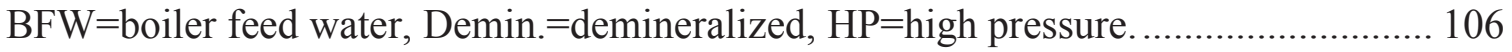
Table A5.2a: Water use for each feedstock in gallons of water per kg of biofuel assuming $2 \%$ and $5 \%$ water consumption for cooling water $(\mathrm{CW})$ and boiler feed water $(\mathrm{BFW})$, respectively 107 Table A5.2b: Water use for each feedstock in gallons of water per kg of biofuel assuming $2 \%$ and $5 \%$ water consumption for cooling water $(\mathrm{CW})$ and boiler feed water $(\mathrm{BFW})$ respectively 108 Table A6.1: GHG emissions for stabilized pyrolysis oil derived from sugarcane bagasse using both displacement and energy allocation with two functional units of metric tons of stabilized pyrolysis oil and MJ of stabilized pyrolysis oil 109 Table A6.2: CED for stabilized pyrolysis oil derived from sugarcane bagasse using displacement allocation with a functional unit of one MJ of stabilized pyrolysis oil..... 111 Table A6.3: FED for stabilized pyrolysis oil derived from sugarcane bagasse using displacement allocation with a functional unit of one MJ of stabilized pyrolysis oil..... 111 Table A6.4: GHG emissions for stabilized pyrolysis oil derived from guinea grass using both displacement and energy allocation with two functional units of metric tons of stabilized pyrolysis oil and MJ of stabilized pyrolysis oil ........................................ 112 Table A6.5: CED for stabilized pyrolysis oil derived from guinea grass using displacement allocation with a functional unit of one MJ of stabilized pyrolysis oil.... 114 Table A6.6: FED for stabilized pyrolysis oil derived from guinea grass using displacement allocation with a functional unit of one MJ of stabilized pyrolysis oil..... 114 Table A6.7: GHG emissions for stabilized pyrolysis oil derived from open pond algae using both displacement and energy allocation with two functional units of metric tons of stabilized pyrolysis oil and MJ of stabilized pyrolysis oil ......................................... 115 Table A6.8: CED for stabilized pyrolysis oil derived from open pond algae using displacement allocation and assuming no nutrient recycle with a functional unit of one MJ of stabilized pyrolysis oil

Table A6.9: FED for stabilized pyrolysis oil derived from open pond algae using displacement allocation and assuming no nutrient recycle with a functional unit of one MJ of stabilized pyrolysis oil.

Table A6.10: GHG emissions for stabilized pyrolysis oil derived from corn stover using both displacement and energy allocation with two functional units of metric tons of stabilized pyrolysis oil and MJ of stabilized pyrolysis oil ........................................ 118 Table A6.11: CED for stabilized pyrolysis oil derived from corn stover using displacement allocation with a functional unit of one MJ of stabilized pyrolysis oil..... 120 Table A6.12: FED for stabilized pyrolysis oil derived from corn stover using displacement allocation with a functional unit of one. 120 
Table A6.13 GHG emissions for stabilized pyrolysis oil derived from low ash corn stover using both displacement and energy allocation with two functional units of metric tons of stabilized pyrolysis oil and MJ of stabilized pyrolysis oil 121

Table A6.14: CED for stabilized pyrolysis oil derived from low ash corn stover using displacement allocation with a functional unit of one MJ of stabilized pyrolysis oil..... 123 Table A6.15: FED for stabilized pyrolysis oil derived from low ash corn stover using displacement allocation with a functional unit of one MJ of stabilized pyrolysis oil.... 123 Table A6.16: GHG emissions for stabilized pyrolysis oil derived from switchgrass using both displacement and energy allocation with two functional units of metric tons of stabilized pyrolysis oil and MJ of stabilized pyrolysis oil ....................................... 124 Table A6.17: CED for stabilized pyrolysis oil derived from switchgrass using displacement allocation with a functional unit of one MJ of stabilized pyrolysis oil.... 126 Table A6.18: FED for stabilized pyrolysis oil derived from switchgrass using displacement allocation with a functional unit of one MJ of stabilized pyrolysis oil..... 126 Table A6.19: GHG emissions for stabilized pyrolysis oil derived from waste wood using both displacement and energy allocation with two functional units of metric tons of stabilized pyrolysis oil and MJ of stabilized pyrolysis oil ....................................... 127 Table A6.20: CED for stabilized pyrolysis oil derived from waste wood using displacement allocation with a functional unit of one MJ of stabilized pyrolysis oil.... 129 Table A6.21: FED for stabilized pyrolysis oil derived from waste wood using displacement allocation with a functional unit of one MJ of stabilized pyrolysis oil.... 129 Table A6.22: GHG emissions for stabilized pyrolysis oil derived from wild algae using both displacement and energy allocation with two functional units of metric tons of stabilized pyrolysis oil and MJ of stabilized pyrolysis oil

Table A6.23: CED for stabilized pyrolysis oil derived from wild using displacement allocation and no wastewater treatment credit with a functional unit of one MJ of stabilized pyrolysis oil

Table A6.24: FED for stabilized pyrolysis oil derived from wild using displacement allocation and no wastewater treatment credit with a functional unit of one MJ of stabilized pyrolysis oil

Table A6.25: GHG emissions for biofuel derived from sugarcane bagasse using both displacement and energy allocation with two functional units of metric tons of biofuel and $\mathrm{MJ}$ of biofuel

Table A6.26: CED for biofuel derived from sugarcane bagasse using displacement allocation with a functional unit of one $\mathrm{MJ}$ of biofuel.

Table A6.27: FED for biofuel derived from sugarcane bagasse using displacement allocation with a functional unit of one $\mathrm{MJ}$ of biofuel.

Table A6.28: GHG emissions for biofuel derived from guinea grass using both displacement and energy allocation with two functional units of metric tons of biofuel and $\mathrm{MJ}$ of biofuel

Table A6.29: CED for biofuel derived from guinea grass using displacement allocation with a functional unit of one MJ of biofuel 136 Table A6.30: FED for biofuel derived from guinea grass using displacement allocation with a functional unit of one MJ of biofuel 
Table A6.31: GHG emissions for biofuel derived from open pond algae using both displacement and energy allocation with two functional units of metric tons of biofuel and $\mathrm{MJ}$ of biofuel

Table A6.32: CED for biofuel derived from open pond algae using displacement allocation with a functional unit of one MJ of biofuel............................................. 138

Table A6.33: FED for biofuel derived from open pond algae using displacement allocation with a functional unit of one MJ of biofuel...

Table A6.34: GHG emissions for biofuel derived from corn stover using both displacement and energy allocation with two functional units of metric tons of biofuel and MJ of biofuel.

Table A6.35: Comparison of literature (Kauffman et al. 2011) GHG emission to MTU/UOP GHG emissions

Table A6.36: CED for biofuel derived from corn stover using displacement allocation with a functional unit of one $\mathrm{MJ}$ of biofuel.

Table A6.37: FED for biofuel derived from corn stover using displacement allocation with a functional unit of one $\mathrm{MJ}$ of biofuel

Table A6.38: GHG emissions for biofuel derived from low ash corn stover using both displacement and energy allocation with two functional units of metric tons of biofuel and $\mathrm{MJ}$ of biofuel

Table A6.39: CED for biofuel derived from low ash corn stover using displacement

allocation with a functional unit of one MJ of biofuel...

Table A6.40: FED for biofuel derived from low ash corn stover using displacement allocation with a functional unit of one $\mathrm{MJ}$ of biofuel.....

Table A6.41: GHG emissions for biofuel derived from switchgrass using both displacement and energy allocation with two functional units of metric tons of biofuel and $\mathrm{MJ}$ of biofuel.....

Table A6.42: CED for biofuel derived from switchgrass using displacement allocation with a functional unit of one MJ of biofuel ....

Table A6.43: FED for biofuel derived from switchgrass using displacement allocation with a functional unit of one MJ of biofuel

Table A6.44: GHG emissions for biofuel derived from waste wood using both displacement and energy allocation with two functional units of metric tons of biofuel and $\mathrm{MJ}$ of biofuel

Table A6.45: CED for biofuel derived from waste wood using displacement allocation with a functional unit of one MJ of biofuel

Table A6.46: FED for biofuel derived from waste wood using displacement allocation with a functional unit of one $\mathrm{MJ}$ of biofuel

Table A6.47: GHG emissions for biofuel derived from wild algae using both displacement and energy allocation with two functional units of metric tons of biofuel and $\mathrm{MJ}$ of biofuel

Table A6.48: CED for biofuel derived from wild algae using displacement allocation with a functional unit of one MJ of biofuel

Table A6.49: FED for biofuel derived from wild algae using displacement allocation with a functional unit of one MJ of biofuel 150 


\section{List of Figures}

Figure 1.1: Map with locations of each feedstock in the United States........................... 5 Figure 1.2: Overall process pathway configuration the IBR process. Dashed arrows indicate recycle of material and energy between processing steps. Solid arrows indicate

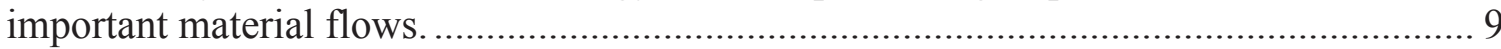

Figure 2.1: System boundary for the LCA with some inputs and co-products................ 19

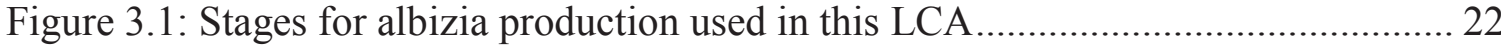

Figure 3.2: Stages for switchgrass production used in this LCA................................... 23

Figure 3.3: System boundaries for wild algae production ........................................... 27

Figure 3.4: System boundaries for open pond algae production .................................... 28

Figure 3.5: Stages for production of waste wood in Washington State.......................... 32

Figure 3.6: Process stages for guinea grass in the Hawaiian Islands............................. 34

Figure 3.7: GHG emissions of sugar cane ethanol production, comparing CARB results

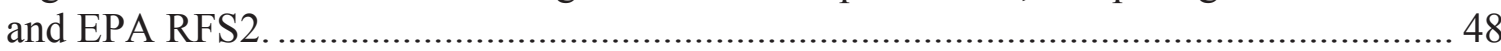

Figure 3.8: GHG emissions of corn stover, comparing SimaPro simulation and CARB

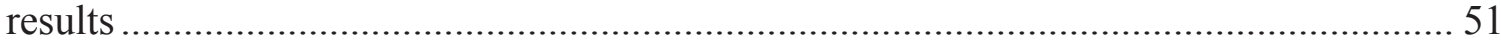

Figure 4.1: Process flow diagram for stabilized pyrolysis oil including significant inputs

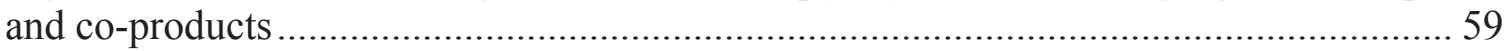

Figure 5.1: Simplified Block flow diagram of the upgrading process........................... 69 Figure 6.1 GHG emissions showing each stage of each biofuel with a functional unit of 1 MJ of biofuel for displacement allocation 79

Figure 6.2 FED of each biofuel with a functional unit of one MJ of Biofuel for displacement allocation 80

Figure 6.3 Total CED for each biofuel with a function unit of one MJ for displacement allocation.....

Figure 6.4 GHG emissions of each biofuel with a functional unit of $1 \mathrm{MJ}$ of biofuel for displacement allocation.

Figure 6.5 Total FED for each biofuel with a function unit of one MJ for displacement

allocation

Figure 6.6 Total FED for each biofuel with a function unit of one MJ for displacement allocation 


\section{Preface}

This thesis is based on several life cycle assessments. The waste wood life cycle assessment was completed and the corresponding section was written by Edwin Maleche and myself. The guinea grass and corn stover life cycle assessment was completed and the corresponding section was written by Jiqing Fan and myself. The remaining life cycle assessments and sections of my thesis were completed and written by myself with the help of my advisor Dr. Shonnard. 


\author{
Abbreviation Definition List \\ Pyoil - Pyrolysis Oil \\ Biooil - Biofuel oil \\ LCA- Life Cycle Assessment \\ LHV- Lower Heating Value \\ EAF- Energy Allocation Factor \\ EA- Energy Allocation \\ LA-Low Ash \\ Dis. - Displacement \\ IBR- Integrated Biorefinery \\ GHG- Greenhouse Gas \\ RFS- Renewable Fuel Standard \\ ILUC- indirect Land Use Change \\ DLUC- direct Land Use Change \\ BDMTD- Bone dry metric tons per day \\ MDT - Million dry tons \\ MT- Metric tons \\ CW-Cooling Water \\ BFW- Boiler Feed Water \\ RTP- Rapid Thermal Process \\ FED- Fossil Energy Demand \\ CED- Cumulative Energy Demand
}


GWP-Global Warming Potential 


\section{Abstract}

Renewable hydrocarbon biofuels are being investigated as possible alternatives to conventional liquid transportation fossil fuels like gasoline, kerosene (aviation fuel), and diesel. A diverse range of biomass feedstocks such as corn stover, sugarcane bagasse, switchgrass, waste wood, and algae, are being evaluated as candidates for pyrolysis and catalytic upgrading to produce drop-in hydrocarbon fuels. This research has developed preliminary life cycle assessments (LCA) for each feedstock-specific pathway and compared the greenhouse gas (GHG) emissions of the hydrocarbon biofuels to current fossil fuels. As a comprehensive study, this analysis attempts to account for all of the GHG emissions associated with each feedstock pathway through the entire life cycle. Emissions from all stages including feedstock production, land use change, pyrolysis, stabilizing the pyrolysis oil for transport and storage, and upgrading the stabilized pyrolysis oil to a hydrocarbon fuel are included. In addition to GHG emissions, the energy requirements and water use have been evaluated over the entire life cycle. The goal of this research is to help understand the relative advantages and disadvantages of the feedstocks and the resultant hydrocarbon biofuels based on three environmental indicators; GHG emissions, energy demand, and water utilization. Results indicate that liquid hydrocarbon biofuels produced through this pyrolysis-based pathway can achieve greenhouse gas emission savings of greater than 50\% compared to petroleum fuels, thus potentially qualifying these biofuels under the US EPA RFS2 program. GHG emissions from biofuels ranged from 10.7-74.3 g/MJ from biofuels derived from sugarcane bagasse and wild algae at the extremes of this range, respectively. The cumulative energy demand (CED) shows that energy in every biofuel process is primarily from renewable biomass and the remaining energy demand is mostly from fossil fuels. The CED for biofuel range from 1.25-3.25 MJ/MJ from biofuels derived from sugarcane bagasse to wild algae respectively, while the other feedstock-derived biofuels are around $2 \mathrm{MJ} / \mathrm{MJ}$. Water utilization is primarily from cooling water use during the pyrolysis stage if irrigation is 
not used during the feedstock production stage. Water use ranges from 1.7 - 17.2 gallons of water per $\mathrm{kg}$ of biofuel from sugarcane bagasse to open pond algae, respectively. 


\section{Chapter 1: Introduction to Pyrolysis Based Liquid Hydrocarbon Transportation Fuels}

\subsection{Importance of Biofuels in the United States}

\subsubsection{Energy Security/Reduction in Imports}

As of $2007,59 \%$ of the oil in the United States was imported from foreign countries and $69 \%$ of that oil was used in the transportation sector (Global Insight 2008). Since the U.S. relies heavy on oil imports, certain countries could cripple the U.S. economy if an oil embargo was placed on the U.S. from oil producing countries such as the oil embargo of 1973 by the Organization of the Petroleum Exporting Countries (OPEC). To improve energy security, the U.S. needs to supply its own transportation energy by producing alternatives to imported petroleum, such as biofuels. Creating biofuels in the U.S. is important because much of the economy is tied to the price of oil. If the U.S. produced its own transportation fuels, conflict in the Middle East and other oil-producing regions would not affect the U.S. economy as much. Relying heavily on oil imports could weaken the U.S. economy and strengthen foreign economies; while use of locally produced biofuels may help stabilize transportation fuel prices, create rural jobs, decrease national expenditures on imported petroleum, and generally help the U.S. economy (Global Insight 2008).

\subsubsection{Water Quality}

Fertilizer use contributes to eutrophication of surface water and dead zones in lakes and oceans, such as in the Gulf of Mexico starting at the Mississippi River delta. Nutrient run off causes algae blooms, which leaves the water with little oxygen. Many marine animals can't live without this oxygen and therefore the nutrient run off creates these dead zones. 
Different feedstocks require different amounts of nutrients. Feedstocks that use large amounts of nitrogen and phosphorus fertilizers could potential contribute significantly to these dead zones.

Another concern with water quality is tillage on marginal land, which moves sediments, fertilizers, and herbicides into river and lakes. Native grasses like switchgrass reduce erosion on marginal lands, which will improve water quality by reducing erosion.

\subsubsection{Land Use Change}

Indirect land use change (iLUC) and direct land use change (dLUC) can contribute a large amount of GHG emissions to the overall life cycle of pyrolysis based biofuels. dLUC emissions are due to changes in GHG emissions when land is converted to biofuel production; from carbon stock changes and net changes in emission of all greenhouse gases. Carbon stock changes are proportional to changes in net uptake or release of $\mathrm{CO}_{2}$ from the atmosphere. For example, crops such as switchgrass take in $\mathrm{CO}_{2}$ from the atmosphere as well as nutrients from the soil to grow. When switchgrass is harvested the roots are left in the soil and carbon is stored in the soil. If carbon levels above ground and in the soil increase, a GHG emission credit is given to the biofuel, but if there is less carbon in the soil due to biofuels production than the GHG emissions in the biofuel life cycle increase. iLUC emissions may occur when land currently in food crop production is used for biofuel production. While this situation could incur dLUC emissions as described above, there may also be an indirect emission when natural lands elsewhere in the world are converted to food crop production to make up for the lost food production. iLUC emissions are determined using global economic models of the agricultural sector in order to understand the effects of biofuel induced food price changes on the conversion of lands. If feedstocks are not food crops like corn, or do not use farm land then iLUC is less of a concern for that feedstock (Eisentraut 2010). 


\subsubsection{Other Factors Affecting GHG Emissions of Biofuels}

There are many other environmental factors pertaining to biofuels that may affect the GHG emissions;

1. Choice of primary energy for heat and power

2. Distance and mode of transport for feedstocks and biofuel products

3. Fertilization for feedstock production, including $\mathrm{N}_{2} \mathrm{O}$ emissions from the land after application.

4. The allocation of emissions to co-products

Another aspect of this LCA involves the carbon dioxide used in photosynthesis when the plant grows. This carbon dioxide could be taken as a credit but this carbon dioxide is then release when the final transportation fuel is processed and combusted. In this study this "biogenic" carbon dioxide is not accounted for during feedstock production, conversion to biofuels, or combustion, but rather a focus is taken on fossil fuels and emissions of fossil $\mathrm{CO}_{2}$. This LCA also looks at the types of energy used to produce each biofuel (fossil and renewable) to understand how important fossil fuels are to the processing of the biofuels.

\subsubsection{Jobs/Rural Development}

Millions of new jobs relating to renewable transportation fuels are expected in the next several decades. Many jobs in engineering, legal, and research \& consulting will also be added as a result of increasing use of alternative transportation fuels (Global Insight 2008). Rural jobs will also be created by planting energy crops, used to produce biofuels, on land that is not suitable for farming food crops. Job growth is less in rural areas compared to urban areas and rural poverty is on the rise (Ellis 2011). Biofuels production would help rural families by providing more jobs that would also help insure energy 
security for the United States. Green jobs, some of which would be related to biofuels production and use, could contribute up to $10 \%$ of new jobs in the United States in the next several decades (Global Insight 2008). Renewable transportation fuels have the potential to create a huge industry and create jobs for a wide variety of people in the United States.

\subsection{Background on Rapid Thermal Processing of Biofuels}

\subsubsection{Feedstock Production}

In this study, many feedstocks are being modeled from data provided by several companies and individuals as shown in table 1.2. These feedstocks are being modeled to better understand the effect of feedstock type on the environmental impacts of pyrolysisbased biofuels. Figure 1.1 shows representative locations for cultivation of the various biomass feedstocks used in this study based on information from feedstock providers in this study. Waste wood includes all the tree branches and some stumps and roots produced during lumber harvesting, assuming a location in Washington State. Corn Stover is the stalk and leaves of corn that is left in the field after corn grain harvest, and it is assumed to be cultivated in the Midwest of the U.S. Switchgrass can be grown in much of the United States as shown in Figure 1.1, especially in the Southeast and in MidAtlantic states. Sugarcane bagasse is a lignocellulosic waste product from sugar cane processing assuming sugar cane grown in the southern states of the U.S. and in Brazil, among other countries. Algae can be grown in regions with ample sun year-round, abundant water supplies, and where nutrient runoff causes blooms in rivers and lakes. One promising region is in the southwestern part of the United States, where land is not suitable for food crops and where sun shines most of the year, and where deep saline aquifers may provide a water resource. Guinea grass and albizia, which are invasive grass and tree species, respectively, grow wild in Hawaii. These feedstocks are being studied as possible energy crops to produce renewable hydrocarbon transportation biofuels. 


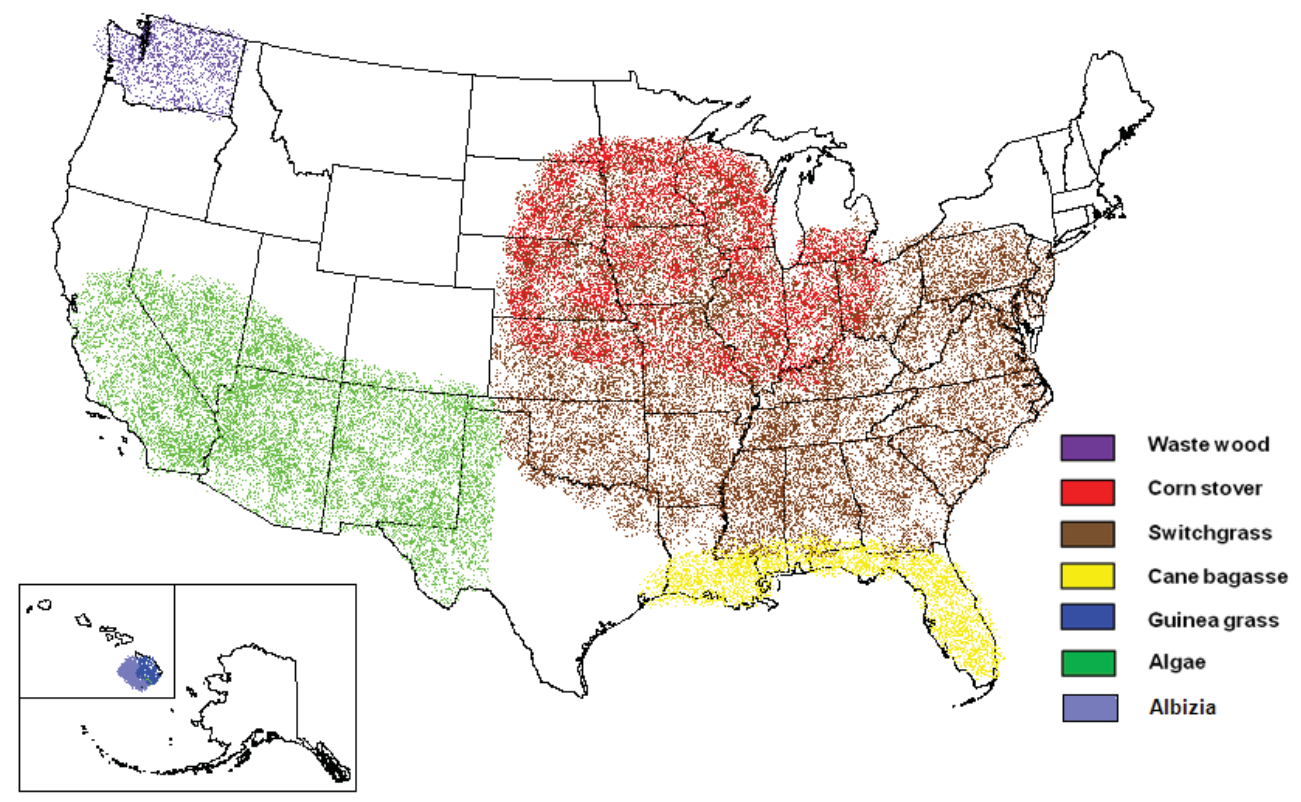

Figure 1.1: Map with locations of each feedstock in the United States

\subsubsection{Land Requirements}

The calculations of land required are based on an upgrading facility processing 2,800 bone dry metric tons per day (BDMTD) of biomass feedstock, which equates to 96.7 million gallons of biofuel per year based on switchgrass yields provided by Ceres. For reasons of economy of scale, a high biomass input rate is preferred for a commercialscale advanced biofuel production facility. Multiple satellite pyrolysis facilities would provide the liquid feedstock to the upgrading facility. Using the data inputs from each feedstock provider and the assumed 2,800 BDMTD facility input rate, the amount of land that is required was calculated and is shown in the Table 1.1 below. The land required for wild algae could not be calculated because the yield, or concentration, was given in terms of a volume $\left(\mathrm{m}^{3}\right)$. The energy per unit area is also calculated using the yield and lower heating value (LHV) and is shown in the table below. 
Table 1.1: Land and Energy Requirements for a 2,800 BDMTD for each Feedstock

\begin{tabular}{|c|c|c|c|c|c|c|}
\hline Feedstocks & $\begin{array}{c}\text { Yields } \\
\text { (MT/ha } \\
\text { /yr) }\end{array}$ & $\begin{array}{c}\text { LHV } \\
\text { (MJ/kg) }\end{array}$ & Hectares & acres & $\mathbf{m i}^{2}$ & $\begin{array}{l}\text { Energy } \\
\text { (GJ/ha) }\end{array}$ \\
\hline Switchgrass & 13.6 & 16.4 & 75,400 & 186,200 & 291 & 222 \\
\hline $\begin{array}{l}\text { Guinea grass } \\
\text { (managed) }\end{array}$ & 19.4 & 14.8 & 52,700 & 130,100 & 203 & 287 \\
\hline $\begin{array}{l}\text { Guinea grass } \\
\text { (unmanaged) }\end{array}$ & 9.7 & 14.8 & 105,000 & 260,200 & 407 & 143 \\
\hline Wild Algae & & 16.4 & & & & \\
\hline $\begin{array}{l}\text { Open pond } \\
\text { Algae }\end{array}$ & 91 & 20 & 11,200 & 27,700 & 43.4 & 1,820 \\
\hline Waste wood & 2.5 & 20 & 409,000 & $1,010,000$ & 1578 & 50 \\
\hline Corn stover & 6.3 & 16.7 & 162,000 & 401,000 & 626 & 105 \\
\hline Cane bagasse & 24.6 & 13.7 & 41,500 & 103,000 & 160 & 336 \\
\hline Albizia & 22.4 & 20 & 45,600 & 112,700 & 176 & 448 \\
\hline
\end{tabular}

Table 1.1 shows that the open pond algae has the highest yield and therefore requires the least amount of area while waste wood has the lowest yield and therefore requires the most land. Open pond algae has the highest yield and highest LHV and therefore the highest energy per unit area. Waste wood has the lowest yield and highest LHV, but because the yield is so low the energy per unit area is the lowest out of all the feedstocks. The sources and references for the yields and LHV data are shown in Table 1.2 below. 
Table 1.2: Yield and LHV references for each feedstock

\begin{tabular}{lcc}
\hline \multicolumn{1}{c}{ Feedstocks } & $\begin{array}{c}\text { Yield sources and } \\
\text { references }\end{array}$ & $\begin{array}{c}\text { LHV sources and } \\
\text { references }\end{array}$ \\
\hline Switchgrass & Ceres ${ }^{(1)}$ & $\mathrm{UOP}^{(\text {Inc.) }}$ \\
Guinea grass (managed) & David Ringuette ${ }^{(3)}$ & UOP \\
Guinea grass (unmanaged) & David Ringuette & UOP \\
Wild Algae & No data & UOP \\
Open pond Algae & (Stratton et al. 2010) & Assumption \\
Waste wood & U.P. Survey & Grays Harbor ${ }^{(4)}$ \\
Corn stover & (Morey et al. 2010) & (Morey et al. 2010) \\
Cane bagasse & (U.S. Department of & (CARB 2009a) \\
Albizia & Energy 2011) & Assumption \\
\hline
\end{tabular}

(1) Contact Sam Harris and Spencer Swayze

(2) Contact Tom Kalnes

(3) University of Hawaii consultant to Imperium

(4) Contact Bruce McComas

\subsubsection{Feedstock Availability}

It is important to know how much of each feedstock is available. If it is not possible to obtain large amounts of each feedstock it will not be possible to make large quantities of biofuels. Also, the feedstock must be harvested in a sustainable manner to insure economic, social, and environmental sustainability. Table 1.3 below shows the amount of feedstock that can be sustainable harvested in the United States according to a recent national study.

Table 1.3: The amount of feedstock that is available annually and can be sustainably harvested in million dry metric tons per year (MDT) (U.S. Department of Energy 2011)

Feedstock Availability

(MDT/yr)

\begin{tabular}{lc}
\hline Waste wood & 45 \\
Corn Stover & 20 \\
Sugarcane bagasse & 1.1 \\
\hline
\end{tabular}


This study assumed that seven 400 BDMTD RTP satellite units, which would produce stabilized pyrolysis biooil feedstock for a central upgrading unit, and this approximately equates to 1 million dry metric tons/yr. This shows that even sugarcane bagasse, could still produce enough biomass for a central upgrading unit. Therefore, the available waste wood and stover feedstocks could produce stabilized pyrolysis biooil for approximately 45 and 20 commercial-scale upgrading units around the United States, respectively. Other feedstocks such as algae, albizia, switchgrass, and guinea grass are not currently commercially available and the current potential feedstock amount has not been estimated. Of course, the optimum scale of a commercial advanced biofuels production facility will be a complex function of the overall biofuel economic viability, but this high level analysis provides preliminary estimates of magnitude of the number of commercial scale facilities needed to utilize the entire sustainable feedstock supply for the types listed in Table 1.3.

\subsubsection{Integrated Biorefinery for Production of Biofuel}

Figure 1.2 provides a simplified block flow diagram of the Integrated Bio-Refinery (IBR) concept as defined by UOP LLC, focusing only on this life cycle stage and showing some "upstream" and "downstream" inputs and outputs, as well as some products and co-products (steam and filter cake). The final products are gasoline, kerosene, and diesel, which are combined and for the purpose of this study into a functional unit called "biofuel”. 


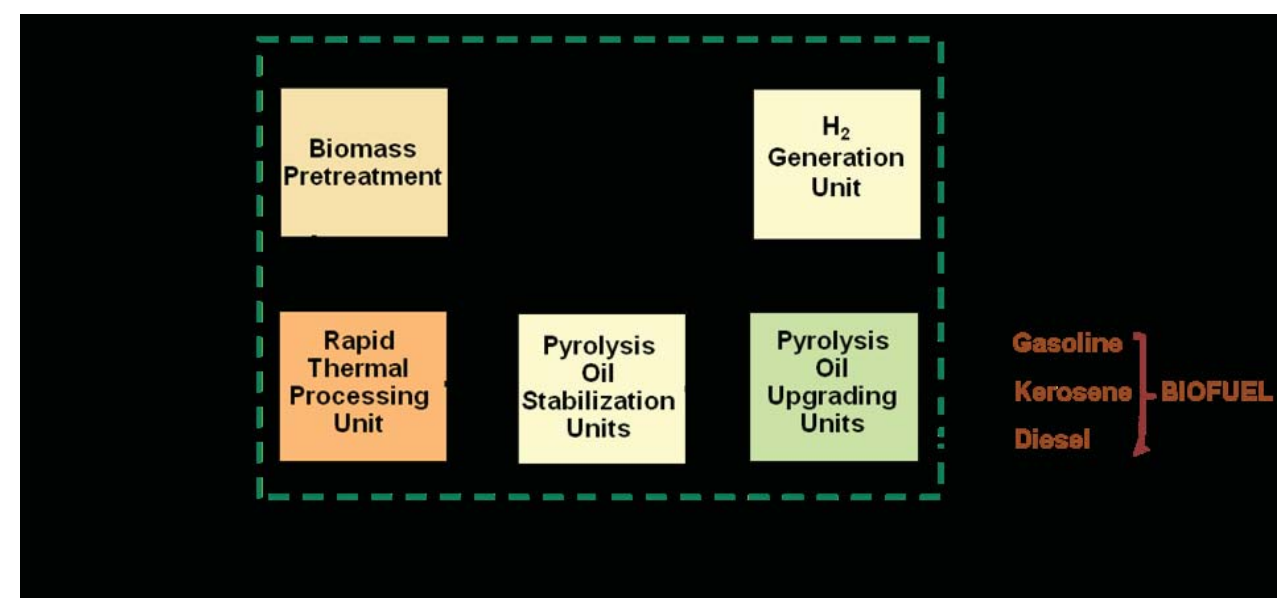

Figure 1.2: Overall process pathway configuration the IBR process. Dashed arrows indicate recycle of material and energy between processing steps. Solid arrows indicate important material flows.

\subsubsection{Rapid Thermal Processing (Fast Pyrolysis)}

After the biomass has been produced and transported to a pyrolysis facility, it is then converted to pyrolysis bio-oil. For this study, we assume that this pyrolysis step is done by the Ensyn (http://www.ensyn.com) Rapid Thermal Process (RTPTM) technology, which is a commercially practiced fast pyrolysis process. This process feedstock is small $(<6 \mathrm{~mm})$ particles of dried biomass $\left(5-6 \%\right.$ moisture) that are rapidly heated up to $500^{\circ} \mathrm{C}$ by hot sand in an oxygen free atmosphere. The resultant vapors are separated from sand and char and then rapidly cooled to condense the bio-oil. This process produces byproducts of char and fuel gas, which are combusted to provide process heat to dry the original biomass, and in some cases to produce a steam co-product. The main product that is produced is called pyrolysis oil or $\mathrm{RTP}^{\mathrm{TM}}$ green fuel, which is a liquid oxygenated organics (hydroxyl, carbonyl, and carboxyl group components) - based fuel. This product must be stabilized before it is stored because otherwise the oil will become too viscous due to the polymerization reactions and therefore will not be suitable for transportation fuel (Diebold and Czernik 1997). 


\subsubsection{Stabilization}

Stabilization involves two steps. The first step filters solid char from the pyrolysis oil. This char is considered a co-product, which could be used as a stand-alone solid fuel or used to co-fire with coal. After the pyrolysis oil is filtered it is transported to the upgrading facility, where stabilization is completed. The second step in stabilization uses ion exchange to remove metals coming from the ash portion of the biomass, which are catalyst poisons. This stage also uses ethanol as a flush solvent in the ion exchange unit, which becomes part of the demetallized liquid and is later converted to ethane in the upgrading step.

\subsubsection{Upgrading}

After the pyrolysis oil is stabilized it is then hydroprocessed to produce three grades of hydrocarbon biofuels, which include gasoline, kerosene, and diesel. Stabilized pyrolysis oil is almost completely deoxygenated by hydrodeoxgenation and decarboxylation reactions. The required hydrogen is produced in the hydrogen generation unit (steam reforming) using the co-products, which are $\mathrm{C} 1-\mathrm{C} 4$ hydrocarbons generated in the upgrader and ethane from the ethanol used in the stabilization stage, as well as supplemental amounts of natural gas for feedstock and fuel. Steam is generated during both the upgrading and hydrogen generation steps and a portion of this steam is exported from the process as a co-product. 


\subsection{Sustainability Issues of Biomass and Biofuels}

\subsubsection{Sustainability Background}

The production of pyrolysis based biofuels has the potential to be economically, socially, and environmentally sustainable, depending on which feedstock is used to produce the biofuel. For example, the commercial implementation of cellulosic biofuel technology will stimulate the market for agricultural by-products like sugar cane bagasse, corn stover, and forest residues and provide the opportunity for farmers or woody biomass producers to increase the amount of revenue per unit area. Additional rural jobs will be created to harvest and transport these residual feedstocks, and engineers and operators will be employed to convert these feedstocks into biofuels. Finally, biofuels are good for the environment because they would replace fossil fuels, which in most cases emit higher levels of GHG emissions (Eisentraut 2010).

When looking at the environmental acceptability of pyrolysis based biofuels, the feedstock used to produce these biofuels needs to be cultivated and harvested in a sustainable manner. There are many sustainability criteria that could be used to evaluate biofuels, including GHG emissions and savings, which will be discussed thoroughly in other sections of this thesis, soil erosion, nutrient runoff and leaching, land use change, water use, and biomass yield. Erosion must be minimized so valuable soil and nutrients are not lost. Fertilizer use should be controlled and reduced because fertilizers are derived from fossil fuels, and runoff / leaching cause water pollution and surface water eutrophication (excess algae growth and then oxygen depletion). Feedstocks should not compete with food crops because of the potential to increase global food prices and impact from iLUC GHG emissions. Minimal or no irrigation should be used to conserved fresh water, which will be discussed in another section. Lastly, the biomass yield needs to be considered because higher yields would require less land for any given biofuels production target. 


\subsubsection{Switchgrass/Guinea Grass Sustainability Issues}

Switchgrass and guinea grass show potential as a feedstock for biofuels production because many aspects associated with these feedstocks are sustainable. As energy crops they have several attributes including high yields, relatively small nutrient inputs, and the ability to grow on marginal lands. Because these crops can be grown on marginal lands, they would not directly compete with food crops, thereby avoiding food price inflation and iLUC effects. Since the yields are high compared to other biomass resources (corn stover for example), less land would be devoted to feedstock production if they were used as a biofuel feedstock. Finally, according to the feedstock suppliers in our study, neither of these crops require irrigation which is beneficial for water conservation.

Guinea grass currently grows wild on the Hawaiian Islands and is concentrated on abandoned pineapple plantations. Guinea grass could be harvested now on unmanaged land, which would result in far less inputs but the yield would be reduced by half of what is possible with managed land (Table 1.1). With no inputs from fertilizers, less fossil fuels would be required, because fossil fuels are used to produce fertilizers. However, more fuel would be used in the harvest stage because twice as much land would be required than if the land was managed.

Growing exclusively switchgrass would limit biodiversity, which could lead to a greater risk of plant disease and reduced wildlife diversity. However, if other native grasses were grown with switchgrass this would increase the biodiversity of the plantations and decrease these negative effects. Switchgrass is also native to North America so there is little threat that this feedstock will become invasive like other potential feedstocks (U.S. Department of Energy 2011). 


\subsubsection{Waste Wood Sustainability Issues}

Waste wood has no fertilizer requirements, does not require irrigation, and does not compete with food crops. However, waste wood exhibits the lowest yield compared to other feedstocks in this study, which means that waste wood derived biofuels require more land to produce the same amount of biofuels when compared to other feedstocks. Less inputs like fertilizers result in lower GHG emissions and decreased fossil fuel use, but relatively longer transportation distances for waste wood would be a disadvantage. There are also no water inputs for irrigation, which is beneficial to water conservation. Finally, waste wood does not compete with food production and as a result would have no iLUC emissions associated with a biofuels produced from this feedstock.

Waste wood serves many purposes in the forests of the United States. These branches serve as natural habits for wild life and some plants grow in rotten and decaying wood. Also, once the wood decays it returns nutrients to the soils that are essential to the forest. Waste wood also helps reduce erosion, which could remove a lot of soil and nutrients that are needed for a healthy forest. When using waste wood as a biofuel feedstock, the natural processes should be considered when deciding on at how much waste can be sustainably removed (U.S. Department of Energy 2011).

\subsubsection{Crop Residues Sustainability Issues}

Crop residues like corn stover and sugar cane bagasse provide many environmental benefits to the ecosystem. Harvesting too much corn stover could result in an increase in agricultural soil erosion, which could result in a large amount of soil and nutrient contamination in local water systems. Also, residues trap moisture in the soil and replenish the soil with nutrients. Only a certain percent of residues can sustainably be harvested. Sustainable harvest is based on two criteria, the soil loss limit cannot be exceeded, and there can be no long-term loss of soil organic matter (U.S. Department of 
Energy 2011). By meeting these two criteria crop residues can be harvested for biofuel production. Sugar cane residues can also be harvest but most of the residue called bagasse is currently being used as a fuel and only a portion of the residue called waste is recommended by the billion ton study to be used as a feedstock (U.S. Department of Energy 2011).

The use of corn stover as a biofuel feedstock does require fertilizers to be returned to corn fields to replace the nutrients lost from corn stover collection. Reliance on fertilizers and fossil fuels is a disadvantage compared to other feedstocks like sugarcane bagasse, which do not require fertilizers. Corn stover is viewed as a waste product in this study and therefore does not carry any burden from corn cultivation and harvesting. One of the scenarios in this thesis looks at stover as a co-product, where these corn-related burdens are accounted for. Unlike corn stover, sugarcane bagasse is collected from a sugar production facility and therefore no fertilizer losses are associated with bagasse use as a biofuel feedstock because bagasse is removed from the land as a normal part of cane processing. Sugarcane is not produced as much as corn in the United States so much more corn stover is available domestically and therefore more domestic biofuel could be produced.

\subsubsection{Algae Sustainability Issues}

In this study both wild algae and open pond algae are investigated as possible feedstocks. Wild algae has many sustainable benefits including no inputs to cultivate because nutrients are from runoff from agriculture and other lands and for cases where algae is grown using nutrients in wastewater. This latter case can potentially realize a credit for avoided emissions during wastewater treatment. Open pond algae is cultivated in efficient engineered systems. Both types of algae have high yields, high energy densities, and do not directly compete with food production. Because wild algae grows naturally in water from the nutrients available, no inputs for wild algae cultivation is required. In contrast, open pond algae requires inputs such as fertilizers and carbon dioxide but requires less 
electricity to harvest than wild algae because raceway algae grows to higher density. Algae grown in wastewater helps eliminate nutrients in effluents that may need to be removed during secondary wastewater treatment. Both types of algae have no iLUC impacts because open pond algae can be grown in raceway ponds where agriculture is not suitable, and wild algae grows naturally and does not use land where food crops can be produced. Another benefit is that a large amount of biomass energy can be harvested from algae in a small area because of the high biomass yields.

\subsubsection{Albizia Sustainability Issues}

Albizia is an invasive tree that grows on the Hawaiian Islands. This tree has many sustainable qualities that could make this a good feedstock. Albizia is a nitrogen-fixing plant, and therefore requires no $\mathrm{N}$ fertilizer inputs, it grows 60 feet after ten years, and sequesters carbon in the soil on abandoned pineapple plantation. Albizia can be grown in low nutrient soils and this tree grows rapidly which would increase the yield compared to other biomass feedstocks.

\subsection{A Review of LCA of Pyrolysis-Based Biofuels and Bioenergy}

There are several published reports that address LCA of pyrolysis based fuels and power. The Kauffman et al. study (Kauffman et al. 2011) was based on a similar pyrolysis process (similar to the Envergent process). This study was based on corn stover as the feedstock. The biofuel pathway included feedstock production, pyrolysis, upgrading and biofuel use in vehicles, but did not include stabilization prior to upgrading. Kauffman et al. (2011) apply large displacement credits to the diesel product for co-products gasoline and biochar. Credits were also applied for sequestering atmospheric $\mathrm{C}$ in the biochar. The study assumed that the pyrolysis stage was fully integrated so there were no other process inputs, such as heat and electricity, downstream of the biomass pretreatment. The last difference compared to this study is that Kauffman et al. (2011) used the LCA model 
GREET, which is a tool developed by the Department of Energy to estimate GHG emissions of alternative-fuel vehicle transportation pathways, while this study (UOPMTU) used SimaPro software to determine the GHG emissions. In this study gasoline is one of the main components of the final product called a mixed biofuel. This mixed biofuel includes gasoline, kerosene, and diesel. Also, in the UOP-MTU LCA study biochar is combusted and the resultant heat is used internally to displace fossil fuels and therefore no excess char or sequestration of $\mathrm{C}$ in the char is taken into account. The UOPMTU study considers other co-products, steam from several of the processing stages as well as filter cake (a solid fuel) from the stabilization process. There are also many inputs in pyrolysis including electricity that Kauffman et al. (2011) does not consider based on integration of the process within an existing facility.

The Hsu report (Hsu 2011) used mass and energy balance inputs from a PNNL report (Jones et al. 2009) for the pyrolysis and upgrading inputs, which are similar to UOPMTU study inputs. The PNNL study considered forest residues as the feedstock. The Hsu report however had $27 \%$ of the net GHG emissions come from electricity production and only $6 \%$ of the GHG emissions came from hydrogen production. The Hsu report chose the ecoprofile "Natural gas, high pressure, at consumer/RER" and replaced the electricity usage with US grid electricity. This selection of natural gas as source of hydrogen does not account for all of the $\mathrm{CO}_{2}$ emissions generated during the steam methane reforming process to produce hydrogen. There is an emission of $\mathrm{CO}_{2}$ in the Hsu report for upgrading but it does not agree stoichiometrically to the amount that would be produced by the natural gas that was used to produce the hydrogen through steam reforming. Also, in this report stabilization was not considered nor were there any credits for steam coproduction. (Jones et al. 2009).

The Fan et al. report (Fan et al. 2011) modeled the life cycle impacts of producing pyrolysis oil from several woody feedstocks, and with the pyrolysis oil being combusted to produce electricity. The inputs for feedstock production, pretreatment, and pyrolysis are similar to this current UOP-MTU study except there was no steam generated during 
pyrolysis and less electricity was used in the pyrolysis step in the Fan et al. study (2011). Also, the transportation distance is higher for forest residues in the Fan et al. (2011) study. For this UOP-MTU study the transportation distances for forest residues are similar to the poplar and willow transportation distances in the Fan et al. (2011) report.

Although there are prior studies and reports on the LCA of pyrolysis-based liquid transportation biofuels, there are also limitations to these prior studies. There is a relative lack of focus on different biomass feedstocks and what effects that feedstocks have on the LCA results, particularly the impact of feedstock on greenhouse gas emissions is not well understood. Pyrolysis-based biofuel production is a fast evolving technology and there is a continued need to update prior LCAs with new inputs, such as inputs for stabilization. Based on these limitations, the following research objectives are identified.

\subsection{Research Objectives}

1. Develop complete LCA analyses for the production of each feedstock on the basis of 1 dry metric ton of feedstock.

2. Develop complete LCA analyses for stabilized pyrolysis oils from each feedstock on the basis of $1 \mathrm{MJ}$ of stabilized pyrolysis oil.

3. Develop complete LCA analyses for each pyrolysis-based biofuels on the basis of $1 \mathrm{MJ}$ of total transportation fuel produced (gasoline+diesel+kerosene).

4. To gain an understanding of the relative importance of biofuel pathway stages by organizing LCA results for each feedstock-specific pyrolysis-based biofuel around each stage.

5. To investigate the relative importance of key LCA inputs through scenario analyses

6. Make recommendations on ways to reduce environmental impacts of pyrolysisbased biofuels produced from select biomass feedstocks. 


\section{Chapter 2: Life Cycle Assessment: Background and Assumptions}

\subsection{Goal and Scope}

The main goal of this life cycle assessment (LCA) is to help the research sponsor, UOP LLC (a Honeywell Company), to understand the environmental impacts of producing and using pyrolysis-based liquid transportation fuels from a range of biomass feedstocks. Results from this research will be used by the sponsor to help make engineering design decisions with regard to unit operations choices and operating conditions. The scope of the study is limited to four impacts; the GHG emissions, cumulative energy demand (CED), fossil energy demand (FED), and water use for the entire life cycle of each pyrolysis-based biofuel.

\subsection{Target Audience}

Many people may read this thesis, including the DOE, UOP, facility, staff, and students from MTU and other university, and other LCA experts. This thesis is intended to give detailed information on inputs and a scientific discussion on the results. Background information will also be provided on the IBR processing stages, including pyrolysis, stabilization, and upgrading, as well as feedstock production.

\subsection{Functional Unit}

This thesis is organized into three sections. Each section utilizes a different functional unit. The first section is feedstock production and the functional unit is one dry metric ton of biomass feedstock. The next section includes feedstock pretreatment, pyrolysis, and stabilization and the functional units examined are $1 \mathrm{MJ}$ of stabilized pyoil and 1 metric ton of stabilized pyoil. The last section covers upgrading of stabilized pyrolysis oil to 
drop-in hydrocarbon biofuels and includes the entire life cycle. The functional unit considered in this section are $1 \mathrm{MJ}$ of biofuel and 1 metric ton of biofuel.

\subsection{System Boundaries and Description of Product System}

The system boundary is the complete life cycle from cradle-to-grave. Figure 2.1 shows each stage in the life cycle, including major inputs and outputs, from feedstock production to biofuel combustion in an engine. In the feedstock production stage, this study includes inputs such as fertilizer requirements, fuel (including electricity) for harvesting or collecting each feedstock, and transporting feedstock to the RTP facility After feedstock production, each feedstock has electricity inputs to reduce the size of the feedstock in preparation for pyrolysis, in a stage called pretreatment. Pyrolysis has inputs like natural gas and electricity used to and dry heat the biomass up to approximately $500^{\circ} \mathrm{C}$. The pyrolysis oil needs to be stabilized, which has electricity inputs, chemicals for ion exchange, and ethanol as a rinse solvent. The last stage is upgrading to hydrocarbon biofuels and the main input is natural gas used for fuel and to produce hydrogen to hyrdoprocess the stabilized pyoil. Most of these stages also require either cooling water, boiler feed water, or rinse water or some combination of water resources.

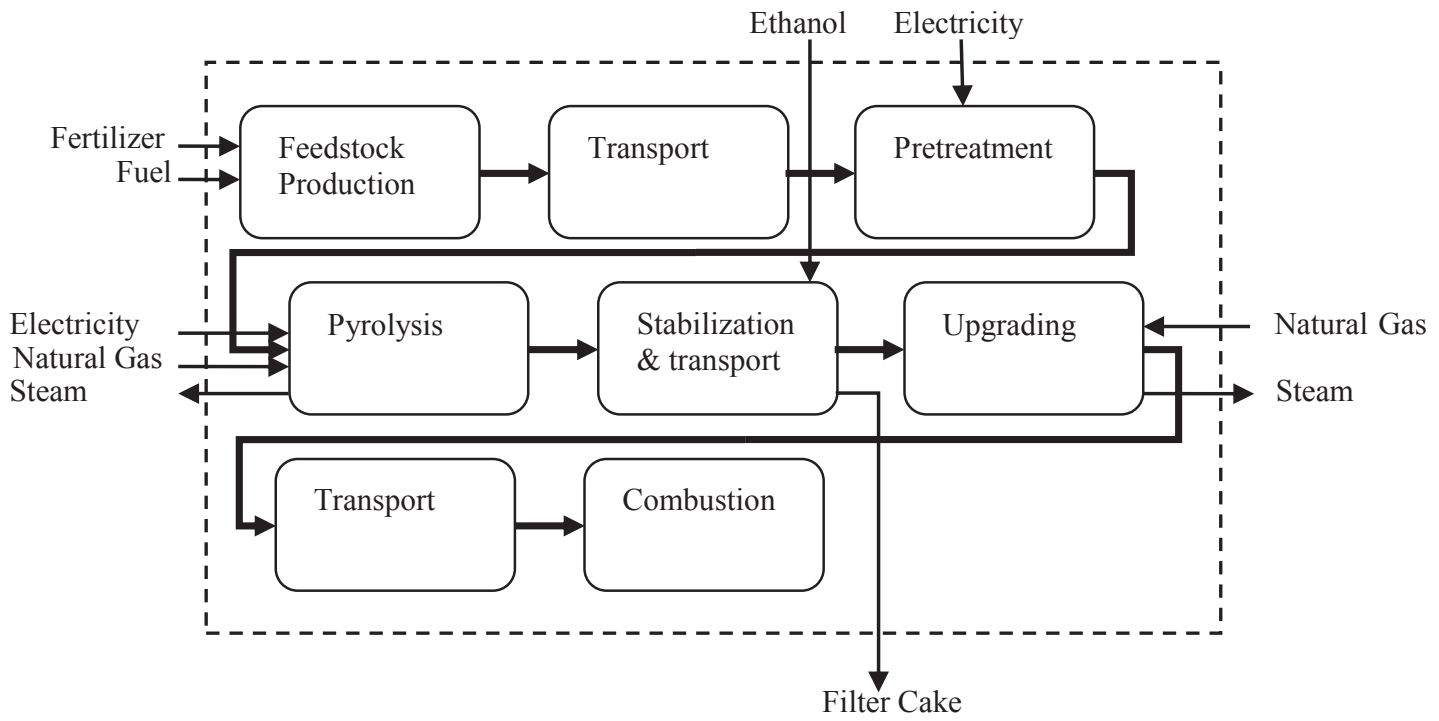

Figure 2.1: System boundary for the LCA with some inputs and co-products 


\subsection{Allocation}

In nearly every LCA of a specific product, there can be many co-products created within the same product system. Co-products are allocated a portion of the environmental burdens from the product life cycle by using different methodologies, such as energy or displacement allocation. In this LCA there are multiple co-products, which are shown in Figure 2.1 and will be discussed in detail in chapters 4 and 5. Other product system outputs were considered waste and therefore did not carry any environmental burdens. The filter cake and steam, has a high energy content and could be used as fuel were considered co-products and therefore shared a portion of the environmental burdens. This study looked at two ways of allocating life cycle impacts to the co-products. The first is displacement, which assigns all environmental burdens to the transportation biofuels and then takes an emissions credit for the avoided products in the market displaced by the coproduct. For example, steam is produced in more than one stage of the product life cycle as shown in Figure 2.1. Steam is exported from the product system and is available for use in the industrial sphere where it may displace steam generated by natural gas, fuel oil, or coal. When displacement occurs, an environmental credit equal to the impact avoided can be claimed by the main product. In the results this credit will show up as a negative emission and helps offset the other emissions in the process. Displacement allocation (also referred to as system expansion) is used by the U.S. Environmental Protection Agency to evaluate biofuels and determine whether they count toward the Renewable Fuels Standard production targets.

The other type of allocation used in this study was energy allocation. This methodology attributes part of the burden to the co-products and only a fraction of the total emissions are assigned to the main product. This allocation approach ratios the output energy that is carried with the main product to the total output energy. This energy allocation calculation occurs at each life cycle stage for which one or more co-products are produced. The fraction of emissions applied to the main product is called the energy allocation factor (EAF). The energy allocation factor is applied not only to this stage but 
also to all upstream stages. The calculation below shows how to calculate the EAF for the pyrolysis stage in Figure 2.1 for which the main product is pyrolysis oil (pyoil) and the co-product is steam (in this example for albizia as a feedstock). The numerator is the energy of the pyoil (pyoil mass multiplied by the lower heating value (LHV) of pyoil) and the denominator is the total output energy. Table 2.1 summarizes all the EAFs for each stage and each feedstock. Energy content of steam was taken to be $3.2 \mathrm{MJ} / \mathrm{kg}$ of steam, obtained from a steam ecoprofile in the LCA software SimaPro, which represents the total primary energy required to produce $1 \mathrm{~kg}$ of average chemical process industry steam.

$\mathrm{EAF}=\frac{1 \frac{\mathrm{kg} \text { of pyoil }}{\mathrm{kg} \text { of pyoil }} * 16.6 \frac{\mathrm{MJ} \text { of pyoil }}{\mathrm{kg} \text { of pyoil }}}{1 \frac{\mathrm{kg} \text { of pyoil }}{\mathrm{kg} \text { of pyoil }} * 16.6 \frac{\mathrm{MJ} \text { of pyoil }}{\mathrm{kg} \text { of pyoil }}+0.78 \frac{\mathrm{kg} \text { of steam }}{\mathrm{kg} \text { of pyoil }} * 3.2 \frac{\mathrm{MJ} \text { of steam }}{\mathrm{kg} \text { of steam }}}=0.87$

Table 2.1: EAFs for each feedstock at each stage. Calculations are shown for each EAF in the Appendix 2.

\begin{tabular}{lccc}
\hline & Pyrolysis & Stabilization & Upgrading \\
\hline Albizia & 0.87 & 0.95 & 0.80 \\
Corn Stover & 0.88 & 0.93 & 0.83 \\
Corn Stover Low Ash & 0.77 & 0.94 & 0.82 \\
Switchgrass & 0.89 & 0.95 & 0.81 \\
Guinea Grass & 0.97 & 0.96 & 0.82 \\
Sugarcane Bagasse & 0.93 & 0.96 & 0.85 \\
Waste Wood & 0.83 & 0.95 & 0.83 \\
Wild Algae & 0.97 & 0.92 & 0.84 \\
Open Pond Algae & 0.91 & 0.95 & 0.85 \\
\hline
\end{tabular}




\section{Chapter 3: Inputs and Results for Feedstock Production}

\subsection{Feedstock Production Inputs}

\subsubsection{Albizia}

The goal of this analysis is to estimate GHG emissions from the albizia supply chain in the context of a Hawaiian location. No data was available from albizia growers, so inputs were assumed similar to a study conducted in the Upper Peninsula of Michigan, which had inputs for mixed hardwood logging residue collection and transport from natural regeneration hardwood site near Trenary, MI, and Grays Harbor's inputs for chipping and grinding as shown in Table A3.1 in Appendix 3. Figure 3.1 shows the albizia supply chain for feedstock production.

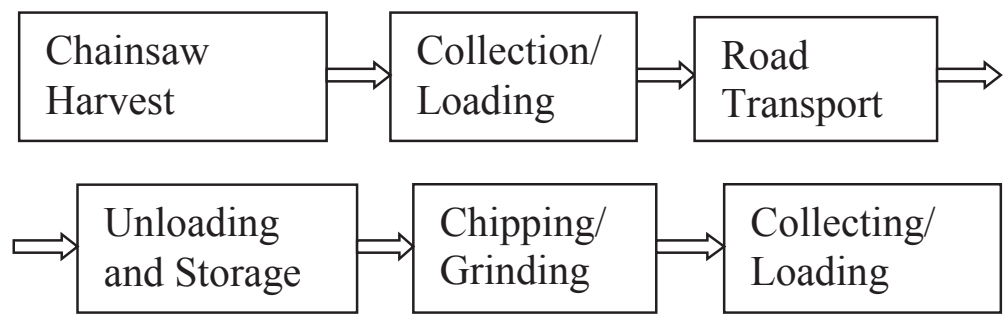

Figure 3.1: Stages for albizia production used in this LCA

Albizia inputs were assumed to be similar to waste wood with the exception of a harvesting step. This process assumes most of the harvesting of albizia will be selective harvesting. Albizia is considered an invasive species in Hawaii and plantations in Hawaii may not be acceptable. Chainsaw harvesting was selected because the trees might grow in hard to reach places where large machines cannot go. When power from the grid is 
required, this analysis assumes a Hawaiian electricity average as shown in appendix 3. The rest of the inputs are diesel for the machines and electricity for chipping.

The truck input takes into account the road infrastructure, operation and vehicle maintenance, expenditures, and environmental interventions due to road construction. The ecoprofile "Building machine" in the ecoinvent database, a surrogate for loading and unloading equipment, was taken into consideration for the unloading and storage stage and the collecting and loading stage, which includes the transportation of the parts to the assembly plant and building the machine.

\subsubsection{Switchgrass}

The goal of the switchgrass analysis is to determine the greenhouse gas (GHG) emissions for planting, cultivation, harvesting, and transportation steps, and to compare GHG results from Ceres input data with GHG results from the literature. Input data upstream of the pyrolysis oil production step was provided by Ceres for various process stages of switchgrass production. Three scenarios with different transportation distances were taken into consideration for switchgrass as well as geographic location scenarios each requiring different amounts of nitrogen fertilizer. Figure 3.2 below shows key stages in the switchgrass production life cycle.

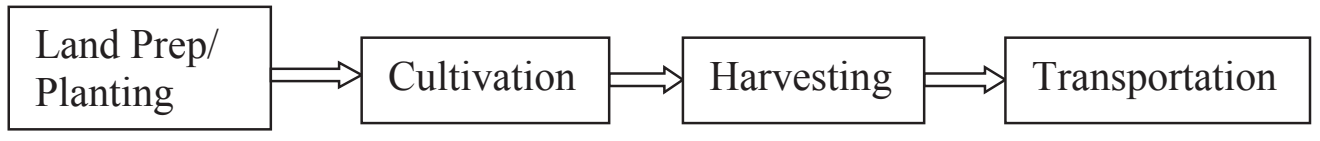

Figure 3.2: Stages for switchgrass production used in this LCA.

The switchgrass feedstock supply chain inputs provided by Ceres are summarized in Table A3.2 for switchgrass. Ceres does not believe that soybean and corn acres will be converted to switchgrass, especially at current corn and soybean prices. More likely, pasture lands and marginal lands no longer profitable for food production will be 
converted. In this initial scenario the stand was established on existing row crop land without any supplemental irrigation. Soil was assumed to have low potassium and phosphorus content with $\mathrm{pH}$ less than 5 therefor lime, potassium, and phosphorus were added. There was no use of pesticides for crop protection and herbicide data was not available, and therefore not input into the analysis. According to Ceres Electricity and natural gas were also not used in the cultivation according to Ceres input data.

Table A3.2 also compares input data from Ceres on switchgrass production to literature data (Cherubini and Jungmeier 2010). Herbicide and switchgrass seed data are not included in this analysis because Ceres did not have inputs and was assumed to have negligible effect on the results, as shown in (Cherubini and Jungmeier 2010). Any inputs that were missing from Ceres were either taken from Ecoinvent database in SimaPro or estimated as shown later in the report. Any input data that was not in the literature was assumed to be the same as the data from the Ceres or the SimaPro inputs were used.

The inputs associated with nitrogen fertilizer for 10 location scenarios are shown in Table A3.3, and annual productivities on the basis of dry mass as listed below.

1. Southeast with low nitrogen input (17.61 MT/ha), where MT is dry metric tons

2. Southeast with high nitrogen input (17.61 MT/ha)

3. Northern plains with low nitrogen input (11.62 MT/ha)

4. Northern plains with high nitrogen input (11.62 MT/ha)

5. Mid-Latitude with low nitrogen input (17.44 MT/ha)

6. Mid-Latitude with high nitrogen input (17.44 MT/ha)

7. Southern plains with low nitrogen input (15.5 MT/ha)

8. Southern plains with high nitrogen input (15.5 MT/ha)

9. Nitrogen balance (inputs to meet the $\mathrm{N}$ taken up during growth)

10. Literature (16 MT/ha) 
Scenario \#9 was named the nitrogen balance scenario. This scenario was calculated using data given from an elemental analysis of dry switchgrass, which was found to contain $0.44 \%$ nitrogen. This means that for every dry metric ton of switchgrass $4.4 \mathrm{~kg}$ of nitrogen are required, assuming all nitrogen is taken up into switchgrass. This assumption is of course an idealization because some $\mathrm{N}$ is lost due to volatilization and leaching, but this scenario provides a benchmark for $\mathrm{N}$ addition. This would seem to represent the minimum amount of nitrogen fertilizer required but input of $\mathrm{N}$ is actually on the high side when comparing to the other eight scenarios, which implies some natural sources of nitrogen.

A switchgrass plot life of seven years was considered in this study and input data was averaged over this time period since the inputs provided by Ceres varied year-to-year according to a cultivation schedule. The fertilizers for potassium and phosphorus were assumed to be potassium sulfate, and monoammonium phosphate. Urea $(50 \%$ of $\mathrm{N}$ in fertilizer), ammonium nitrate ( $50 \%$ of $\mathrm{N}$ in fertilizer), and limestone were identified as inputs and were provide by Ceres. The inputs were all converted to have the same basis; 1 dry metric ton switchgrass. An example of how the input data was calculated for location scenario 1 is given in equation 3.1

$\frac{58.28 \mathrm{~kg} \text { of } \mathrm{N} \text { in fertilizer }}{1 \mathrm{Ha}} * \frac{1 \mathrm{Ha}}{17.61 \mathrm{dry} M T} * \frac{0.5 \mathrm{~kg} \text { of } \mathrm{N} \text { in urea }}{1 \mathrm{~kg} \text { of } \mathrm{N} \text { in fertilizer }}=1.65 \frac{\mathrm{kg} \text { of } \mathrm{N} \text { in urea }}{\text { dry } M T}$

where, $58.28,17.61$ and 0.5 were provided by Ceres. The truck transport inputs during the transportation stages included road infrastructure, expenditures and environmental interventions due to construction, renewal and disposal of roads have been allocated based on ton kilometers, which is provided by the Ecoinvent database of SimaPro7.2. The distance between the bio-refinery and the switchgrass plantations varies so several different scenarios were developed. The scenarios included one way transportation distances of 15,25 , and 50 miles. 
For all of the switchgrass scenarios' harvesting stage and other stages with machinery, $0.006 \mathrm{~kg}$ lubricating oil $/ \mathrm{kg}$ diesel was assumed (from Ecoinvent database of SimaPro7.2) and calculated as

$\frac{43.14 \text { gal of diesel }}{1 \mathrm{Ha}} * \frac{3.785 \mathrm{~L}}{1 \mathrm{gal}} * \frac{0.85 \mathrm{~kg} \text { diesel }}{1 \mathrm{~L} \mathrm{of} \mathrm{diesel}} * \frac{0.006 \mathrm{~kg} \text { lubricating oil }}{\mathrm{kg} \text { diesel }}$
$=0.83 \frac{\mathrm{kg} \text { lubricating oil }}{\text { ha of Switchgrass }}$

where, 43.14 gallons diesel/ha is input data from Ceres and the rest are conversion factors. Hydraulic oil and grease inputs were assumed to be in the same ratio to the diesel fuel consumption as the data provided in published data (ecoinvent data). GHG emissions associated with building the machinery used in the cultivation and harvest stages were calculated using input data available in SimaPro (ecoinvent data).

Direct land use change (dLUC) emissions of $\mathrm{CO}_{2}$ for switchgrass varied greatly depending on location. The dLUC inputs for switchgrass are summarized in Table A3.4 in the appendix. The dLUC emissions of $\mathrm{CO}_{2}$ ranged between -248 (sequestration of $\mathrm{CO}_{2}$ ) to +37 (emission) $\mathrm{kg} \mathrm{CO}_{2} /$ dry MT of switchgrass depending on location. Indirect land use change (iLUC) emissions of $\mathrm{CO}_{2}$ were not included because it is assumed that switchgrass will be grown on marginal land, which would not compete with food crops.

\subsubsection{Wild Algae}

Wild algae is cultivated and harvested using electric pump motors to recover algaecontaining water existing waterways of treatment facilities and process it through equipment that separates the biomass from the water using chemical agents to aid in the separation. Table A3.5 in the appendix shows the wild algae production inputs provided by Aquaflow Bionomic Corporation, while Figure 3.3 shows the main stages including pumping to harvester, harvesting, dewatering, and transport. The transportation distance for shipping the dewatered algae to the IBR facility is assumed to be $100 \mathrm{~km}$ one way. 


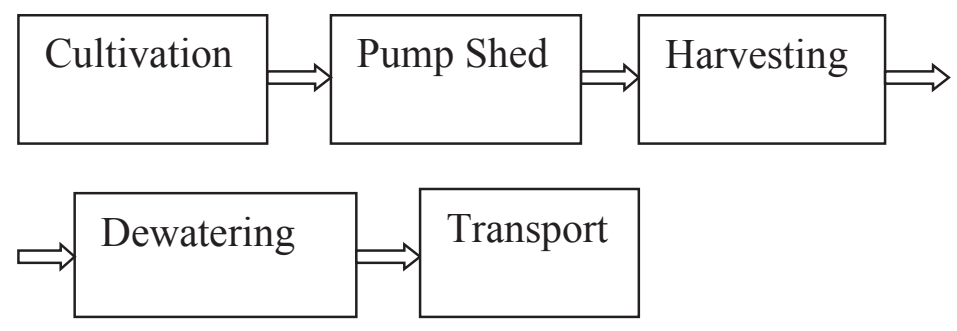

Figure 3.3: System boundaries for wild algae production

A basis of 1 dry metric ton of Algae was used for the data listed in Table A3.5. The main category of inputs for the LCA was the electricity used by the motors. In this analysis it is assumed that the inventory of emissions for the electricity inputs are from US average grid using an ecoprofile from the ecoinvent database in SimaPro and the chemical agents are assumed to be generic organic chemicals (because of lack of data from the biomass supplier). It is assumed that using wastewater treatment nutrients avoids the large emissions associated with the normal wastewater treatment biological nitrogen removal process.

\subsubsection{Open Pond Algae}

Another algae case investigated was open pond algae, and the system boundary for this analysis is shown in Figure 3.4. This algae was assumed to be grown in desert regions in the southwest of the United States. This would avoid any iLUC because it would be grown on land not suitable for farming, however this cultivation method may incur dLUC emissions of $\mathrm{CO}_{2}$ depending on the carbon stocks on the land used prior to algae pond construction (not considered in this thesis). 


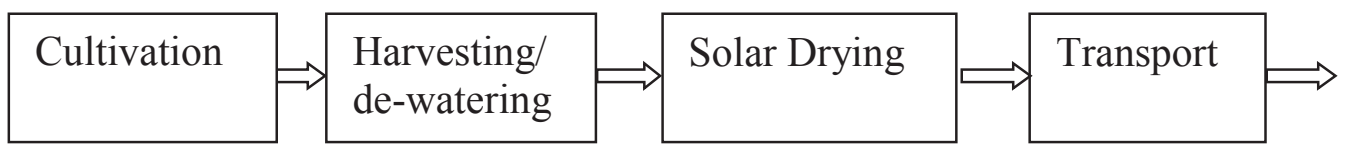

Figure 3.4: System boundaries for open pond algae production

In our study of cultivation of open pond algae, injections of $\mathrm{CO}_{2}$ as well as nutrients like nitrogen, phosphate, and potassium were included. Cultivation also requires water consumption due to water losses in evaporation and electricity for motor-driven equipment used to move water around the system. Harvesting / de-watering require electric pumps to pump solution through a vacuum filter (0.1-3.5\% solids) and into a centrifuge (5-40\% solids) to de-water the algae solution. Solar drying then concentrates the moist mat of algae to $90 \%$ solids. For all electricity inputs US electricity mix was assumed. These inputs are summarized in Table 3.1.

Table 3.1: Inventory data from the report by (Stratton et al. 2010) for open pond algae cultivation, harvesting, drying and transport with a basis of one dry metric ton algae

\begin{tabular}{lcc}
\hline Item & Inputs & Units \\
Cultivation & 2180 & $\mathrm{~kg}$ \\
CO2 requirements & 50 & $\mathrm{kWh}$ \\
Direct injection of $\mathbf{C O}_{2}$ & 53 & $\mathrm{~kg}$ \\
Nitrogen fertilizer as $\left.\mathbf{N}_{(\mathbf{N H}} \mathbf{N O}_{3}\right)$ & 29 & $\mathrm{~kg}$ \\
Superphosphate $\left(\right.$ as $\left.\mathbf{P}_{\mathbf{2}} \mathbf{O}_{5}\right)$ & 30 & $\mathrm{~kg}$ \\
Potassium sulfate $\left(\mathbf{a s} \mathbf{K}_{\mathbf{2}} \mathbf{O}\right)$ & 4.75 & $\mathrm{kWh}$ \\
Nutrient supply & 85.6 & $\mathrm{kWh}$ \\
Mixing & 67.4 & $\mathrm{kWh}$ \\
Water supply & & \\
Harvesting/de-watering & 14.0 & $\mathrm{kWh}$ \\
Vacuum belt filter & 120 & $\mathrm{kWh}$ \\
Dewater 5 - 40\% solids & & \\
Drying Scenario & 7380 & $\mathrm{MJ}$ \\
Natural gas & 100 & $\mathrm{tkm}$ \\
\hline Transportation & & \\
\hline
\end{tabular}

\subsubsection{Cane Bagasse and Corn Stover}

Two scenarios were investigated to calculate GHG emissions for sugar cane bagasse and corn stover as biomass feedstocks for PyGasoline and PyDiesel production. In the first 
scenario, sugar cane bagasse was considered as a co-product of sugarcane ethanol production, and corn stover as a co-product of corn grain harvesting and collection. The second scenario considered both sugarcane bagasse and corn stover as waste products from their original production systems. An energy allocation (Spatari et al.) method was used to determine GHG emissions of production of bagasse and corn stover when these feedstocks were considered as co-products. Other allocation methods may be used in future studies. The EA method involves an energy balance utilizing material flows and lower heating values (LHV) for each material. For bagasse, the system boundary for EA calculation encompasses the entire production chain up to conversion to ethanol, whereas for corn stover the production chain ends with corn harvesting. The EA factor was calculated using the following equations, where the denominator represents the total energy content of all products and numerator is energy content of the co-product only.

$$
\begin{aligned}
& E A_{\text {bagasse }}=\frac{L H V_{\text {bagasse }} \times \text { Mass }_{\text {bagasse }}}{\text { LHV }_{\text {bagasse }} \times \text { Mass }_{\text {bagasse }}+\text { LHV }_{\text {ethanol }} \times \text { Volume }_{\text {ethanol }}} \\
& E A_{\text {stover }}=\frac{L H V_{\text {stover }} \times \text { Mass }_{\text {stover }}}{L H V_{\text {stover }} \times M a S_{\text {stover }}+L H V_{\text {grain }} \times M a s s_{\text {grain }}}
\end{aligned}
$$

The LHVs of ethanol and sugarcane bagasse, as well as the ethanol yield from sugarcane and corn were obtained from the CARB reports (CARB 2009a; 2009b); and the LHV of bagasse and stover are obtained from the literature (Table 1.2).

The environmental burden of sugarcane bagasse was calculated by multiplying GHG emissions from sugarcane ethanol production ( $1.9 \mathrm{~g} \mathrm{CO}$ eq. $/ \mathrm{MJ}$ ethanol produced) by the allocation factor of bagasse (eqn. 3.5). According to the CARB report (CARB 2009a), one tonne of sugarcane (assuming 70\% moisture) can produce 24 gallons of ethanol with $180 \mathrm{~kg}$ dry bagasse as co-product; $154.08 \mathrm{~kg}$ of which are burned to provide heat and electricity for ethanol production and with the remainder available for use as biomass feedstock for PyGasoline and PyDiesel production. Therefore, the energy allocation factor of sugar cane bagasse can be calculated as: 
EA factor $=\frac{(180-154.08) \mathrm{kg} \times 13.66 \mathrm{MJ} / \mathrm{kg}}{24 \mathrm{gal} \times 80.53 \mathrm{MJ} / \mathrm{gal}+(180-154.08) \mathrm{kg} \times 13.66 \mathrm{MJ} / \mathrm{kg}}=0.1548$

This method of estimating the EA factor for bagasse is an over-estimate because bagasse is a co-product from the sugar solution extraction step in the ethanol process, and therefore the emissions from fermentation and distillation to recover ethanol should not be allocated to bagasse.

Similarly, the environmental burden of corn stover was calculated by multiplying GHG emissions of corn farming and harvesting (5.65 $\mathrm{g}$ of $\mathrm{CO}_{2}$ eq. / $\mathrm{MJ}$ of corn ethanol) by the allocation factor of corn stover (eqn. 3.6). According to the CARB report (CARB 2009b), one bushel (56 lb) of corn can produce 2.72/2.62 gallons of ethanol (dry mill/wet mill, respectively). It was assumed that $50 \%$ of the corn consists of corn grain and the remainder is corn stover (from CARB report). The LHVs of corn grain and corn stover are 15.5 and $16.5 \mathrm{MJ} / \mathrm{kg}$, respectively. Therefore, the energy allocation factor of corn stover is calculated as:

EA factor $=\frac{56 \mathrm{lb} * 0.454 \frac{\mathrm{kg}}{\mathrm{lb}} * 50 \% * 16.5 \mathrm{MJ} / \mathrm{kg}}{56 \mathrm{lb} * 0.454 \frac{\mathrm{kg}}{\mathrm{lb}} * 50 \% * 15.5 \frac{\mathrm{MJ}}{\mathrm{kg}}+56 \mathrm{lb} * 0.454 \frac{\mathrm{kg}}{\mathrm{lb}} * 50 \% * 16.5 \frac{\mathrm{MJ}}{\mathrm{kg}}}=51.56 \%$

Corn stover and cane bagasse LCAs were also developed assuming these feedstocks as waste products that come without environmental burden. The inputs are shown in the Table 3.2 for corn stover waste and when considered a co-product and Table 3.3 for cane bagasse waste and when considered a co-product. Another feedstock is low ash corn stover, which is assumed to have the same inputs for feedstock production. This scenario differs from corn stover because low ash corn stover is collected when corn is being processed and so the stover never touches the ground. The inputs for the feedstock production stage for low ash stover are assumed to be the same as for normal stover (lack 
of data on low ash stover). However, inputs for low ash stover will be different compared to normal stover for pyrolysis, stabilization, and upgrading (see chapters $4 \& 5$ ).

Table 3.2: Inputs for corn stover as a waste and also for low ash corn stover with a basis of one dry metric ton of feedstock (Morey et al. 2010)

\begin{tabular}{|c|c|c|}
\hline Life Cycle Stage & Inputs & Units \\
\hline \multicolumn{3}{|l|}{ Collection } \\
\hline \multicolumn{3}{|l|}{ Stalk Shredding } \\
\hline Lubricating oil & 1.29E-03 & gallons \\
\hline Diesel fuel & 0.222 & gallons \\
\hline \multicolumn{3}{|l|}{ Raking } \\
\hline Lubricating oil & $3.53 \mathrm{E}-04$ & gallons \\
\hline Diesel fuel & 0.053 & gallons \\
\hline \multicolumn{3}{|l|}{ Baling } \\
\hline Lubricating oil & $1.29 \mathrm{E}-03$ & gallons \\
\hline Diesel fuel & 0.225 & gallons \\
\hline \multicolumn{3}{|l|}{ Bale moving } \\
\hline Lubricating oil & $2.35 \mathrm{E}-03$ & gallons \\
\hline Diesel fuel & 0.424 & gallons \\
\hline \multicolumn{3}{|l|}{ Loading } \\
\hline Diesel fuel & 0.134 & gallons \\
\hline Lubricating oil & $1.53 \mathrm{E}-03$ & gallons \\
\hline \multicolumn{3}{|l|}{ Transportation } \\
\hline Diesel & 0.408 & gallons \\
\hline Lubricating oil & $2.47 \mathrm{E}-03$ & gallons \\
\hline \multicolumn{3}{|l|}{ Unloading } \\
\hline Diesel fuel & 0.134 & gallons \\
\hline Lubricating oil & $1.53 \mathrm{E}-03$ & gallons \\
\hline \multicolumn{3}{|l|}{ Nutrients Replacement } \\
\hline Ammonia & 9.42 & $\mathrm{~kg}$ \\
\hline Diammonium phosphate & 2.9 & $\mathrm{~kg}$ \\
\hline Potassium sulphate & 12.7 & $\mathrm{~kg}$ \\
\hline
\end{tabular}


Table 3.3: Inputs for the cane bagasse as a waste with a basis of one dry metric ton of feedstock

\begin{tabular}{lcc}
\hline Loading & Inputs & Units \\
$\begin{array}{l}\text { Diesel } \\
\text { Lubricating oil }\end{array}$ & $\begin{array}{c}0.134 \\
1.53 \mathrm{E}-03\end{array}$ & $\begin{array}{l}\text { gallons } \\
\text { gallons }\end{array}$ \\
$\begin{array}{l}\text { Transport } \\
\text { Truck }\end{array}$ & 100 & tkm \\
$\begin{array}{l}\text { Unloading } \\
\text { Diesel }\end{array}$ & 0.134 & gallons \\
Lubricating oil & $1.53 \mathrm{E}-03$ & gallons \\
$\begin{array}{l}\text { Loading } \\
\text { Diesel } \\
\text { Lubricating oil }\end{array}$ & $\begin{array}{c}0.134 \\
1.53 \mathrm{E}-03\end{array}$ & $\begin{array}{l}\text { gallons } \\
\text { gallons }\end{array}$ \\
\hline
\end{tabular}

\subsubsection{Waste Wood}

The goal of this analysis is to estimate GHG emissions from the waste wood supply chain in the context of a Washington state location. The data was collected from Grays Harbor who provides forest feedstock to the Grays Harbor Paper facility. As shown in Figure 3.5, the waste wood supply chain has several stages.

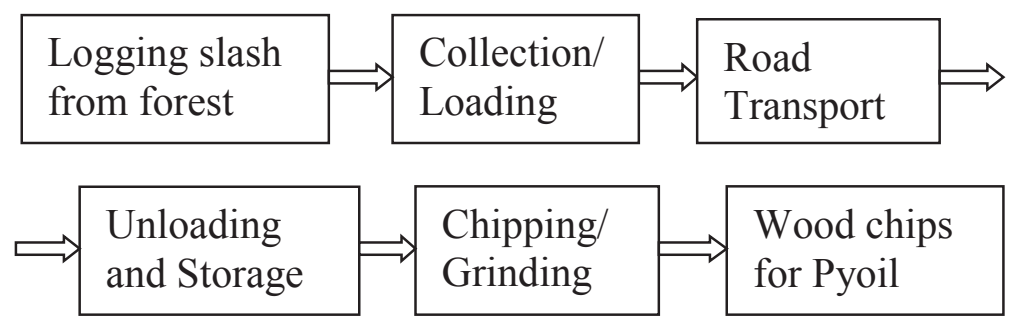

Figure 3.5: Stages for production of waste wood in Washington State.

Some of the inputs in the Table A3.6 in the Appendix were obtained from a UP survey of logging residue collection and transport from a natural regeneration hardwood site near Trenary, MI similar to the Grays Harbor site. Grays Harbor did supply chipping/grinding and road transportation inputs for this LCA. 
The Grays Harbor waste wood analysis used machinery, diesel and electricity for the chipping stage. GHG emissions emitted during the chipping of the waste wood with electric driven equipment assumed a Washington state (U.S. EPA 2005) electrical grid mix, which include the GHG gases of $\mathrm{CO}_{2}, \mathrm{CH}_{4}$, and $\mathrm{N}_{2} \mathrm{O}$. Chipping requires two $450 \mathrm{hp}$ chippers that process 60 green MT every hour. There is also a transmission loss factor of 1.1 (from Ecoinvent database of SimaPro 7.2) and 95\% of the biomass is chipped using electric-powered motors, while the rest requires diesel grinding. Using these inputs the required electricity can be calculated using equation 3.7

$2 * 450 h p * \frac{0.746 K W}{1 h p} * \frac{1 h r}{60 \text { green } M T} * \frac{2 \text { green } M T}{1 \text { dry } M T} * 1.1 * 0.95=23.4 K W h$

The truck inputs take into account the road infrastructure, operation and vehicle maintenance, expenditures, and environmental interventions due to road construction. Building machine was taken into consideration for unloading and storage stage which includes the transportation of the parts to the assembly plant and building the machine.

\subsubsection{Guinea Grass}

Guinea grass (Tenbruggencate) grows wild on the Hawaiian Islands and is concentrated on abandoned pineapple and sugar cane plantations. Currently no fertilizers are being used in GG cultivation but are assumed to be needed once the current nutrients left over from prior crop use are consumed during harvesting. An elemental analysis of a guinea grass sample was performed by Ensyn Technologies and the data was used to estimate future fertilizer needs. Figure 3.6 shows key stages in the guinea grass production life cycle which greenhouse gas emissions will be calculated. 

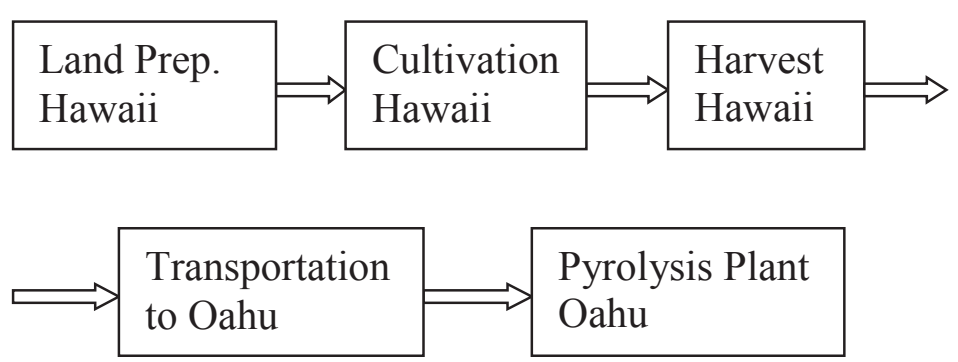

Figure 3.6: Process stages for guinea grass in the Hawaiian Islands.

The first scenario is harvesting wild guinea grass grown on abandoned pineapple and sugar cane fields without inputs of fertilizers. This requires only the harvesting and transportation steps. Two scenarios were also considered for the land preparation step, which was assumed to be needed every 20 years. The results are summarized in Table A3.7.

- Land with minimal vegetation other than guinea grass, 5 gallons diesel/acre

- Land with medium to large trees (require shredder), 15 gallons diesel/acre

Unmanaged land has a lower annual yield of 30 green metric tons as compared to managed land of 60 green metric tons because no fertilizer is added to unmanaged land. Green metric tons refer to the yields after harvesting with some moisture content associated with the yields. An example calculation for the combustion of diesel fuel for the guinea grass land preparation with medium to large trees is shown in equation 3.8

$$
\begin{aligned}
& \frac{15 \mathrm{gal}}{\text { acre }} * \frac{1 \text { acre }}{60 \text { green } M T / y r} * \frac{1 \text { green } M T}{0.80 \text { dry } M T} * \frac{3.785 \mathrm{~L}}{1 \mathrm{gal}} * \frac{0.85 \mathrm{~kg} \text { diesel }}{1 \mathrm{~L}} * \frac{1}{20 \text { years }}= \\
& 0.0503 \frac{\mathrm{kg} \text { of diesel }}{1 \text { dry } M T}
\end{aligned}
$$

where, 15 gal per acre, 60 green MT per acre and the 20\% moisture content (factor of 0.80) were given provided by Imperium, the biomass provider, and also by Professor Dave Ringuette, University of Hawaii. Land preparation was assumed to be needed every 20 years. Diesel consumption associated with guinea grass cultivation was not provided 
and had to be estimated. Switchgrass data was used in this step because switchgrass and guinea grass are similar crops and therefore should have similar diesel cultivation requirements. Fertilizers were assumed to be urea, potassium sulphate, and thomas meal. The elemental analysis of guinea grass sample provided to Ensyn for pyrolysis studies showed 0.7 mass $\%$ nitrogen on a dry basis. This was then converted into a dry MT basis as shown in equation 3.9

$$
\frac{0.007 \mathrm{~kg} \text { of } N \text { fertilizer }}{1 \mathrm{~kg} \text { of } G G} * \frac{1000 \mathrm{~kg}}{1 M T}=7.00 \frac{\mathrm{kg} \text { of } N \text { fertilizer }}{1 \text { dry } M T}
$$

The phosphorous fertilizer was estimated by using a ratio of six parts phosphorus per 16 parts nitrogen, which is similar in most plants. Phosphorous fertilizer was estimated this way because this element was not listed on the elemental analysis from Ensyn. This ratio was then used to calculate the emissions associated with phosphorus. Hydraulic oil and grease were assumed to be same ratio in all stages as data was only supplied for the guinea grass harvest stage. Lubricating oil was estimated by using $0.006 \mathrm{~kg}$ lubricating oil/kg diesel for all machinery in every stage (from Ecoinvent database of SimaPro7.2). The transportation inputs were 100 miles round trip by truck and an assumed distance of 500 miles by oceanic barge from Hawaii to Oahu. Inventory of emissions for these transport steps were obtained using ecoprofiles in the ecoinvent database in SimaPro.

\subsection{Life Cycle Impact Assessment}

The GHG included $\mathrm{N}_{2} \mathrm{O}, \mathrm{CO}_{2}, \mathrm{CH}_{4}$, etc. Each gas is converted to $\mathrm{CO}_{2}$ equivalent using the global warming potential (GWP). Some of the most common GHGs and their GWP are listed below;

1. $\mathrm{CO}_{2}=1.0$

2. $\mathrm{N}_{2} \mathrm{O}=298$

3. $\mathrm{CH}_{4}=25$ 
This study uses the IPCC GWP 100a method, which takes the GWP over 100 years because this time period is the most common choice. The GWP is multiplied by the mass of each $\mathrm{GHG}$ to determine the $\mathrm{CO}_{2}$ eq.

Cumulative energy demand (CED) describes the total amount of energy that is consumed during the life cycle inclusive of both renewable and non-renewable sources. Fossil energy is one of the types of energy that is included in the cumulative energy demand result. The ecoinvent database includes the energy demand for each process and SimaPro uses this database to calculate the cumulative and fossil energy demand for this LCA.

\subsection{Results for Feedstock Production}

\subsubsection{Albizia}

The albizia results are shown in Table 3.4. 
Table 3.4: GHG emissions for albizia production in Hawaii with a basis of one MT of dry albizia (kg CO2 equivalent (eq) emissions)

\begin{tabular}{lc}
\hline Albizia & UP Survey / Grays Harbor \\
\hline Chainsaw Harvest & 0.0784 \\
Lubricating Oil & 0.307 \\
Gasoline & 0.433 \\
Diesel & 2.63 \\
Combustion-Diesel & 1.38 \\
Combustion-Gasoline & \\
Collecting/Loading & 1.75 \\
Diesel & 10.6 \\
Combustion-Diesel & 0.253 \\
Machinery & \\
Transportation & 15.6 \\
Transport truck & 17.3 \\
Transport Barge & \\
Unloading/Storage & 0.971 \\
Diesel & 5.88 \\
Combustion-Diesel & 0.253 \\
Machinery & \\
Chipping and Grinding & 0.0551 \\
Diesel & 0.333 \\
Combustion-Diesel & 18.5 \\
Electricity-Hawaiian & 0.0315 \\
Chipper and Grinder & 1.75 \\
Collecting/Loading & 10.6 \\
Diesel & 0.253 \\
Combustion-Diesel & 88.96 \\
Machinery & \\
Total & \\
\hline
\end{tabular}

The largest GHG emission in this LCA is the emissions from electricity usage in the chipping and grinding stage, which accounts for $18.5 \mathrm{~kg}$ of $\mathrm{CO}_{2}$ eq. out of the total $\mathrm{GHG}$ emissions of $88.96 \mathrm{~kg}$ of $\mathrm{CO}_{2}$ eq. Other high emission inputs include transportation, and the collecting and unloading stages, which included a high amount of diesel use. The rest of the inputs contributed little to the overall GHG emissions.

The cumulative energy demand in Table 3.5 shows the types of energy that is used to produce one MJ of albizia. 
Table 3.5: Cumulative energy demand of albizia production in Hawaii with a basis of one MJ of albizia

\begin{tabular}{lc}
\hline Cumulative Energy Demand & MJ/MJ \\
\hline Non renewable fossil & $5.12 \mathrm{E}-02$ \\
Non renewable nuclear & $1.78 \mathrm{E}-03$ \\
Non renewable biomass & $8.69 \mathrm{E}-08$ \\
Renewable biomass & 1.00 \\
Renewable others & $2.49 \mathrm{E}-05$ \\
Renewable water & $2.86 \mathrm{E}-04$ \\
Total & 1.05 \\
\hline
\end{tabular}

Most of the energy comes from renewable biomass. The next largest amount of energy is non renewable fossil energy, which comes from the diesel use in the collecting and loading stages and electricity in the chipping and grinding stage.

The fossil energy demand shown in Table 3.6, shows what inputs contributes to the non renewable fossil energy used in albizia production.

Table 3.6: Fossil energy demand of albizia production in Hawaii with a basis of one MJ of albizia

\begin{tabular}{lc}
\hline Fossil Energy Demand & MJ/MJ \\
\hline Diesel & $2.55 \mathrm{E}-02$ \\
Transport truck & $1.23 \mathrm{E}-02$ \\
Transport barge & $1.13 \mathrm{E}-02$ \\
Gasoline & $1.23 \mathrm{E}-03$ \\
Remaining & $8.70 \mathrm{E}-04$ \\
Total & $5.12 \mathrm{E}-02$ \\
\hline
\end{tabular}

These results show that most of the fossil energy is from diesel combustion during the collecting and loading operations and for transport, with gasoline and the rest of the inputs contributing little to the overall amount of fossil energy used in this process. 


\subsubsection{Switchgrass}

The switchgrass production results for GHG emissions are shown in the Table 3.7 for all stages, except $\mathrm{N}$ fertilizer application and transport. Table 3.8 displays GHG emissions inclusive of these missing steps from Table 3.7. The average nitrogen location scenario and 50 mile transport scenario will be used for the remaining life cycle.

Table 3.7: Switchgrass GHG emissions for three scenarios at different transportation distances $(15,25$, and 50 miles $)$ with a basis of one dry metric ton and comparison to literature (Cherubini and Jungmeier 2010).

\begin{tabular}{lcc}
\hline Switchgrass Process & Ceres (kg CO 2 eq.) & Literature (kg CO2 eq.) \\
\hline Land prep/planting & 0.20 & 0.23 \\
Cultivation & $37.1^{*}$ & 108 \\
Harvest & 37.2 & 40.9 \\
Transport 15 miles & 5.32 & -- \\
Transport 25 miles & 8.86 & --- \\
Transport 50 miles & 17.7 & --- \\
Transport & --- & 20.4 \\
Total & See table 3.8 & 169.5 \\
\hline
\end{tabular}

*The emission related to nitrogen fertilizer are shown in table 3.8

The nitrogen fertilizer emissions for the nine location scenarios and the total emissions associated with the three distance scenarios are shown in the Table 3.8. 
Table 3.8: Total GHG emissions for Switchgrass including nitrogen fertilizer for all locations and nitrogen balance (\#9) and at varying transportation distances with a basis of one dry metric ton. ( $\mathrm{kg} \mathrm{CO} 2 \mathrm{eq}$ emissions)

\begin{tabular}{lccccc}
\hline & $\mathbf{\# 1}$ & $\mathbf{\# 2}$ & $\mathbf{\# 3}$ & $\mathbf{\# 4}$ & $\mathbf{\# 5}$ \\
\hline Nitrogen Fertilizer & 42.6 & 61.1 & 30.7 & 43.0 & 43.0 \\
Total (15 miles) & 122.4 & 140.9 & 110.5 & 122.8 & 122.8 \\
Total (25 miles) & 126.0 & 144.5 & 114.1 & 126.4 & 126.4 \\
Total (50 miles) & 134.2 & 152.7 & 122.3 & 134.6 & 134.6 \\
\hline
\end{tabular}

\begin{tabular}{lrrrr}
\hline & $\# \mathbf{6}$ & $\mathbf{\# 7}$ & $\mathbf{\# 8}$ & $\mathbf{\# 9}$ \\
\hline Nitrogen Fertilizer & 61.4 & 30.7 & 43.0 & 56.8 \\
Total (15 miles) & 141.2 & 110.5 & 122.8 & 136.6 \\
Total (25 miles) & 144.8 & 114.1 & 126.4 & 140.2 \\
Total (50 miles) & 153.0 & 122.3 & 134.6 & 148.4 \\
\hline
\end{tabular}

Equation 3.10 shows effects of field $\mathrm{N}_{2} \mathrm{O}$ emissions, which is nearly $1 / 3$ of total $\mathrm{GHG}$ emissions for switchgrass (Ceres).

$$
\begin{aligned}
& \frac{58.28 \mathrm{~kg} \mathrm{of} \mathrm{N} \mathrm{Fertilizer}}{1 \mathrm{Ha}} * \frac{1 \mathrm{Ha}}{17.61 \mathrm{dry} \mathrm{MT}} * 1 \mathrm{dry} \mathrm{MT} \text { (basis) } * \frac{0.01325 \mathrm{~kg} \mathrm{of} \mathrm{Nin}_{2} \mathrm{O}}{1 \mathrm{~kg} \mathrm{of} \mathrm{N} \mathrm{fertilizer}} \\
& * \frac{(2 * 14+16) \mathrm{kg} \mathrm{N}_{2} \mathrm{O}}{(2 * 14) \mathrm{kg} \text { of } \mathrm{Nin} \mathrm{N}_{2} \mathrm{O}} * 298\left(\mathrm{GWP} \text { of } \mathrm{N}_{2} \mathrm{O}\right)=20.53 \mathrm{kgCO} \text { eq. }
\end{aligned}
$$

The emissions for each scenario increased with increasing distanced traveled.

Transportation emissions contributed between about 3-9\% if the total depending on distance. The GHG emissions of switchgrass varies between 110.5 and $153.0 \mathrm{~kg} \mathrm{CO} 2$ equivalent for every dry MT of switchgrass depending on the scenario, while the literature value was 169.5 . The difference is largely due to the cultivation step, which involves fertilizers. The nitrogen fertilizers contribute the most to the overall process due to the emissions of $\mathrm{N}_{2} \mathrm{O} . \mathrm{N}_{2} \mathrm{O}$ has a GWP of 298 , which contributes significantly to GHG emissions.

Energy demand results are shown in Table 3.9 for Ceres switchgrass and for switchgrass using literature data. 
Table 3.9: Comparing an average cumulative energy demand of switchgrass with inputs from Ceres and literature (Cherubini and Jungmeier 2010) with a basis of one MJ of switchgrass.

\begin{tabular}{lcc}
\hline Switchgrass & Ceres (MJ/MJ) & Literature (MJ/MJ) \\
\hline Non renewable, fossil & $8.19 \mathrm{E}-02$ & $9.84 \mathrm{E}-02$ \\
Non renewable, nuclear & $6.54 \mathrm{E}-03$ & $6.17 \mathrm{E}-03$ \\
Non renewable, biomass & $7.21 \mathrm{E}-06$ & $3.05 \mathrm{E}-06$ \\
Renewable biomass & 1.00 & 1 \\
Renewable water & $7.94 \mathrm{E}-05$ & $1.29 \mathrm{E}-03$ \\
Renewable others & $1.45 \mathrm{E}-03$ & $7.21 \mathrm{E}-05$ \\
Total & 1.09 & 1.11 \\
\hline
\end{tabular}

The highest impact in the CED calculation is the renewable biomass, which mainly accounts for the inherent energy content of the switchgrass. This renewable biomass was calculated with a lower heating value of 16.37 GJ per metric ton (Table 1.2). Fossil fuels like diesel also contribute to the overall process with a total CED of 1.09 (Ceres) and 1.11 (Literature) MJ while the other categories contribute near negligible amounts.

Table 3.10 breaks down the non renewable fossil energy requirements to illustrate where the fossil energy is being used. The data in this table shows that most of the fossil energy is coming from diesel use and fertilizer production. There are also smaller contributions from transport of switchgrass and machinery production used in cultivation and harvesting.

Table 3.10: Average fossil energy demand of switchgrass with inputs from Ceres with a basis of one MT and MJ of switchgrass.

\begin{tabular}{lc}
\hline Switchgrass & MJ/MJ \\
\hline Diesel & $3.23 \mathrm{E}-02$ \\
Transport & $9.04 \mathrm{E}-03$ \\
Potassium & $8.86 \mathrm{E}-03$ \\
Phosphate & $7.70 \mathrm{E}-03$ \\
Urea & $6.35 \mathrm{E}-03$ \\
Total Fertilizers & $2.85 \mathrm{E}-02$ \\
Machinery production & $8.36 \mathrm{E}-03$ \\
Ammonium nitrate & $5.63 \mathrm{E}-03$ \\
Remaining & $3.68 \mathrm{E}-03$ \\
Total & $8.19 \mathrm{E}-02$ \\
\hline
\end{tabular}




\subsubsection{Wild Algae}

The results for the wild algae LCA were calculated using different types of energy inputs for electricity. The U.S. mix scenario will be used for the rest of the wild algae LCA. The results in Table 3.11 indicate that using coal as a source of energy for the production of the wild algae has the highest greenhouse gas impact, which is $962 \mathrm{~kg} \mathrm{CO}_{2}$ eq per dry MT of algae. The Lowest GHG impact results obtained are from the hydroelectricity power and nuclear energy, which are $164 \mathrm{~kg}$ and $169 \mathrm{~kg} \mathrm{CO}_{2}$ equivalents, respectively. In this study U.S. mix was chosen as the base case electricity source, which release 550 $\mathrm{kg} \mathrm{CO}_{2}$ equivalent. The GHG impacts of wild algae are dependent strongly on location of the production due to the mix of primary energy sources in the electricity mix.

Table 3.11: Comparison of GHG emissions with different electricity derived energies with units of $\mathrm{kg}$ of $\mathrm{CO} 2 \mathrm{eq}$. per dry metric ton of algae and an algae density of $300 \mathrm{~g} / \mathrm{m} 3$.

\begin{tabular}{lccccc}
\hline & Coal & Nuclear & U.S. mix & Hydro & Biomass \\
\hline Pump shed & 627 & 6.43 & 305 & 2.5 & 23 \\
Harvest & 133 & 1.36 & 64.6 & 0.5 & 4.88 \\
De-watering & 185 & 144 & 164 & 144 & 145 \\
Transport & 16.8 & 16.8 & 16.8 & 16.8 & 16.8 \\
Total & 962 & 169 & 550 & 164 & 190 \\
\hline
\end{tabular}

The main categories of the algae production system which are considered for the LCA analysis are pumping at the pump shed, new harvest units, dewatering, and transport. Table 3.11 shows the GHG emissions per one dry metric ton for each stage and assuming different types of derived electricity. The total GHG emissions are $550 \mathrm{~kg} \mathrm{CO}_{2}$ eq. per metric ton dry algae biomass for the U.S. mix energy scenario. The largest contribution to this total is from the pump shed stage, which pumps the water and algae solution throughout the process. De-watering stage uses chemical additives to aid in separating water from the algae biomass and the assumed additives are responsible for the large GHG emission in this stage. 
The algae density contributes significantly to the GHG emissions. If the algae density is doubled, the pump shed and harvest stages will be reduced by $50 \%$ as well as slightly reducing GHG emissions in the de-watering step. Also, the type of derived electricity has a major impact on GHG emissions as can be seen in the Table 3.11.

An alternative scenario that was modeled was a waste water treatment credit for an avoided ammonia removal process using denitrification. In this scenario, wild algae was grown using the nutrients present in a typical wastewater treatment plant effluent. This scenario assumes US Grid electricity, which gives a large credit of $-1250 \mathrm{~kg}$ of CO2 eq. / MT of wild Algae for the impacts avoided when wastewater treatment is replaced with Aquaflow Algae production. To arrive at this result, the inputs from UOP (communication by Steve Lupton) were for the treatment of $1 \mathrm{~m}^{3}$ (1 metric ton) of wastewater containing $50 \mathrm{mg} \mathrm{NH3/L} \mathrm{(0.05} \mathrm{kg} \mathrm{NH3/ton} \mathrm{wastewater).} \mathrm{Because} \mathrm{each} \mathrm{dry}$ ton of algae is $5.8 \% \mathrm{~N}$, then each ton dry biomass contains $58 \mathrm{~kg}$ of $\mathrm{N}$. About $1 / 2$ of the $\mathrm{CO}_{2}$ eq. emissions avoided are from the mineralization of the methanol needed for denitrification of the $\mathrm{NH}_{3}$ in a WWT plant.

Table 3.12 shows the cumulative energy demand for all the electricity scenarios. The LHV was found to be $16.59 \mathrm{GJ}$ per metric ton of algae (Table 1.2). This table shows that renewable biomass represents the largest portion of the CED in all scenarios studied.

Table 3.12: Cumulative energy demand for various types of derived electricity in MJ eq. per MJ of algae

\begin{tabular}{lccccc}
\hline & Coal & Nuclear & U.S. mix & Hydro & Biomass \\
\hline Non renewable fossil & $8.98 \mathrm{E}-01$ & $2.98 \mathrm{E}-01$ & $6.80 \mathrm{E}-01$ & $2.94 \mathrm{E}-01$ & $2.94 \mathrm{E}-01$ \\
Non renewable nuclear & $2.28 \mathrm{E}-02$ & $6.39 \mathrm{E}-01$ & $1.60 \mathrm{E}-01$ & $1.81 \mathrm{E}-02$ & $1.78 \mathrm{E}-02$ \\
Non renewable biomass & $1.41 \mathrm{E}-07$ & $1.12 \mathrm{E}-07$ & $1.81 \mathrm{E}-07$ & $1.02 \mathrm{E}-07$ & $1.00 \mathrm{E}-07$ \\
Renewable biomass & 1.00 & 1.00 & 1.00 & 1.00 & 1.00 \\
Renewable others & $2.50 \mathrm{E}-04$ & $1.86 \mathrm{E}-04$ & $8.44 \mathrm{E}-04$ & $1.81 \mathrm{E}-04$ & $1.77 \mathrm{E}-04$ \\
Renewable water & $2.72 \mathrm{E}-03$ & $2.19 \mathrm{E}-03$ & $1.46 \mathrm{E}-02$ & $1.49 \mathrm{E}-01$ & $1.87 \mathrm{E}-03$ \\
Total & 1.92 & 1.94 & 1.86 & 1.46 & 1.31 \\
\hline
\end{tabular}


The non renewable fossil energy demand was broken down into more detail to show what inputs used the most fossil energy, which is shown in Table 3.13. Electricity and chemicals for nutrients contributed the most to the fossil energy demand, and transportation contributed the rest of the fossil energy. This case assumed U.S. mix of electricity for this analysis.

Table 3.13: Fossil energy demand for U.S. mix electricity scenario with a basis of one MJ

\begin{tabular}{lc}
\hline Fossil Energy Demand U.S. Mix & MJ/MJ \\
\hline Electricity & 0.39 \\
Chemicals & 0.28 \\
Transportation & 0.02 \\
Total & 0.68 \\
\hline
\end{tabular}

\subsubsection{Open Pond Algae}

Open pond algae inputs from the PARTNER report (Stratton et al. 2010) were used to generate the GHG emission results in SimaPro. The results are summarized in Table 3.14. The inputs that contributed the most to the overall GHG emissions were the nutrients. The calculated nutrient- GHG emission was high compared to the PARTNER report value of $115 \mathrm{~kg} \mathrm{CO}_{2}$ eq. per MT of algae (likely due to the assumed $\mathrm{N}$ fertilizer in this thesis research for open pond algae - ammonium nitrate, which has a high GHG emission factor compared to other $\mathrm{N}$ fertilizers). For this preliminary screening, this study uses the PARTNER report values for nutrients instead of the Ecoinvent results from SimaPro (447 $\mathrm{kg}$ of $\mathrm{CO}_{2}$ eq. per dry MT of algae). Other inputs that contributed significantly to the overall GHG emissions electric motor driven pumps used in both the de-watering stage and the cultivation stages. 
Table 3.14: GHG emissions associated with the production of open pond algae with a basis of one dry MT of algae.

\begin{tabular}{lc}
\hline Open Pond Algae & kg CO 2 eq. \\
\hline Cultivation & \\
CO2 requirements & 35 \\
Direct injection of CO & 2 \\
Nitrogen fertilizers & 42 \\
Superphosphate & 453 \\
Potassium sulfate & 74.9 \\
Nutrient supply & 43 \\
Mixing & 3.98 \\
Water supply & 69.2 \\
Harvesting/de-watering & 56.4 \\
Vacuum belt filter & \\
Dewater 5 - 40\% solids & 11.7 \\
Drying & 100 \\
Natural Gas & \\
Transportation & 574 \\
Total (SimaPro nutrient results - solar drying) & 13.7 \\
Total (PARTNER report nutrient results - solar drying) & 903 \\
Total (PARTNER, 75\% nutrient recycle - solar drying) & 447 \\
Total (PARTNER with natural gas drying) & 361 \\
\hline
\end{tabular}

There are two scenarios for open pond algae; the first is $75 \%$ of the nutrients are recycled so only $25 \%$ of the nutrients are required. The other scenario is using natural gas to dry the algae instead of using solar drying. The nutrient recycle reduced the amount of nutrients required and therefore reduced the GHG emissions. The natural gas drying requires $2.05 \mathrm{kWh} / \mathrm{kg}$ of algae. This energy requirement is based on the amount of water that has to be removed and assuming a $70 \%$ efficient drying process, which resulted in an increase of $574 \mathrm{~kg}$ of $\mathrm{CO}_{2}$ per MT of dry algae.

The CED is shown in Table 3.15, which breaks down the types of energy that were used in the production of open pond algae. This shows that renewable biomass contributed significantly to the overall amount of energy because of the large amount of algae that is collected in this process. Non renewable fossil energy also contributed a lot of energy to this process, while the rest contributed lesser amounts. 
Table 3.15: CED for open pond algae production assuming solar drying with a basis of one dry MT of algae

\begin{tabular}{lc}
\hline Cumulative Energy Demand & MJ/MJ \\
\hline Non renewable fossil & $4.06 \mathrm{E}-01$ \\
Non renewable nuclear & $8.86 \mathrm{E}-02$ \\
Non renewable biomass & $2.58 \mathrm{E}-05$ \\
Renewable biomass & 1.01 \\
Renewable others & $7.74 \mathrm{E}-04$ \\
Renewable water & $9.96 \mathrm{E}-03$ \\
Total & 1.51 \\
\hline
\end{tabular}

The fossil energy demand is broken down into more detail in Table 3.16. This table shows that the fossil energy consumption came from the electric motor-driven pumps, nutrient production, and transportation. The electricity needed for the pumps contributed the most fossil energy to open pond algae production.

Table 3.16: FED for open pond algae production with a basis of one dry MT of algae

\begin{tabular}{lc}
\hline Fossil Energy Demand & MJ/MJ \\
\hline Electricity & $1.66 \mathrm{E}-01$ \\
Ammonium nitrate & $1.47 \mathrm{E}-01$ \\
Single superphosphate & $5.03 \mathrm{E}-02$ \\
Potassium sulfate & $3.18 \mathrm{E}-02$ \\
Transport & $1.11 \mathrm{E}-02$ \\
Total & $4.06 \mathrm{E}-1$ \\
\hline
\end{tabular}

\subsubsection{Sugar Cane Bagasse}

The GHG emissions of sugar cane ethanol production generated by SimaPro and CARB are shown in Table 3.17. The results from EPA Renewable Fuels Standard (RFS2) (EPA 2010a) are also listed and compared to the CARB (CARB 2009a)study. 
Table 3.17: GHG emissions of sugar cane ethanol, comparing CARB results to the EPA RFS2.

\begin{tabular}{|c|c|c|c|}
\hline $\mathrm{g} \mathrm{CO}_{2}$ eq./MJ EtOH & SimaPro & CARB & EPA RFS2 \\
\hline Sugar Cane Farming & 9.77 & 9.9 & 36.02 \\
\hline Ag Chemicals Production and Use & 6.18 & 8.7 & Included in Farming \\
\hline Sugar Cane Transport & 3.67 & 2 & 4.74 \\
\hline Ethanol Production & 2.29 & 1.9 & -10.43 \\
\hline LUC (domestic \& international) & & & 4.74 \\
\hline Tailpipe Emission & 0 & 0 & 0.95 \\
\hline Total w/o LUC & 21.92 & 22.5 & 31.28 \\
\hline Total w/ LUC & & & 36.02 \\
\hline
\end{tabular}

* LUC impact for sugar cane ethanol is not included in the CARB report.

As shown in Table 3.17, the total GHG emissions comparing the CARB results and the SimaPro simulation (using CARB inventory data) are very consistent with each other. Agricultural chemicals production and use is a slightly smaller contributor in the SimaPro simulation mainly because SimaPro uses a different GHG calculation method for fertilizer production. Emissions of $\mathrm{N}_{2} \mathrm{O}$ from the farm as a result of $\mathrm{N}$ fertilizer application were included in the SimaPro simulations using IPCC emission factor of $0.0135 \mathrm{~kg} \mathrm{~N}_{2} \mathrm{O}-\mathrm{N} / \mathrm{kg}$ fertilizer $\mathrm{N}$ applied. Averaging the two results (SimaPro and CARB) and multiplying by the calculated EA factor results in total sugar cane bagasse GHG emissions of approximately $3.45 \mathrm{~g} \mathrm{CO}_{2} \mathrm{eq} / \mathrm{MJ}$ EtOH produced. In the RFS2 report, ethanol production emits negative amount of $\mathrm{CO}_{2}$ because of displacement of marginal Brazilian electricity by power generated with the sugarcane bagasse co-product. Domestic LUC accounts for $0.85 \mathrm{~g} \mathrm{CO}_{2} \mathrm{eq} / \mathrm{MJ}$, whereas international LUC impacts range from -4.74 to $11.37 \mathrm{~g} \mathrm{CO}_{2} \mathrm{eq} / \mathrm{MJ} \mathrm{EtOH}$, resulting in a mean emission value of $3.79 \mathrm{~g}$ $\mathrm{CO}_{2} \mathrm{eq} / \mathrm{MJ} \mathrm{EtOH}$ for total LUC.

The conversion factor between MJ of ethanol produced per kg bagasse residue coproduced, based on yields mentioned above and LHV for ethanol, is $1932.72 \mathrm{MJ} \mathrm{EtOH}$ per $25.92 \mathrm{~kg}$ bagasse, resulting in a final value for bagasse of $257.25 \mathrm{gCO}_{2} \mathrm{eq} / \mathrm{kg}$ bagasse, without LUC. Figure 3.7 shows the GHG emissions based on one $\mathrm{kg}$ of bagasse. LUC impacts were included in the CARB results to present a better comparison 
between CARB and RFS2 results. The LUC emission was assumed to be the same as shown in the RFS2 report, and the mean emission value was used for this study is $3.79 \mathrm{~g}$ $\mathrm{CO}_{2}$ eq/MJ EtOH.

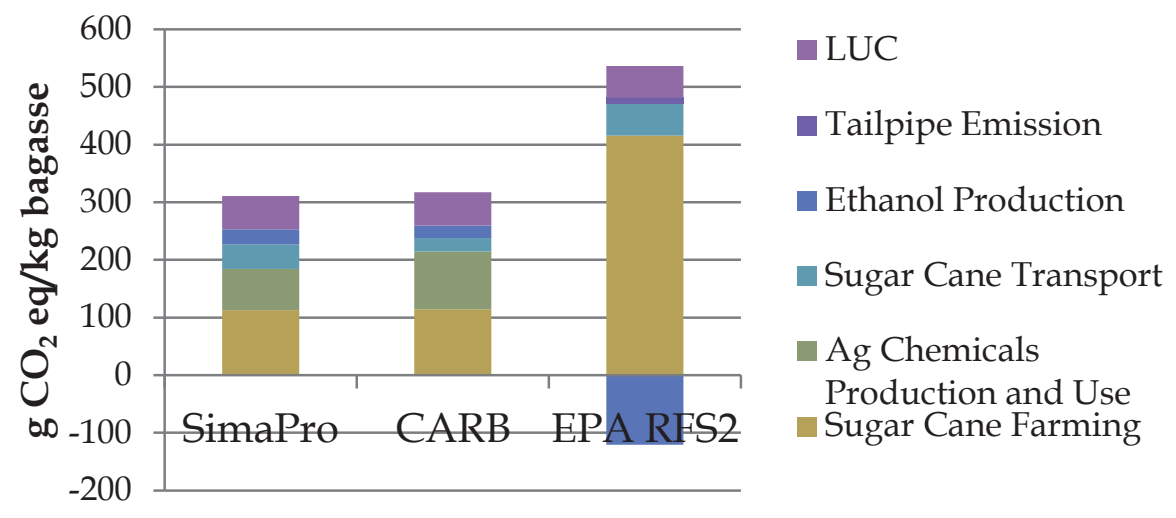

Figure 3.7: GHG emissions of sugar cane ethanol production, comparing CARB results and EPA RFS2.

The next scenario assumed that sugarcane bagasse as a waste product. This means only loading, transport to the biorefinery, and unloading was considered as shown in the Table 3.18 .

Table 3.18: GHG emissions of sugar cane bagasse when considered a waste product in $\mathrm{kg}$ $\mathrm{CO} 2 \mathrm{eq} / \mathrm{metric}$ ton dry bagasse

\begin{tabular}{lc}
\hline Cane Bagasse & $\mathbf{k g ~ C O} 2$ eq. / metric ton cane bagasse \\
\hline Loading & 1.83 \\
Transport & 16.80 \\
Unloading & 1.83 \\
Total & 20.45 \\
\hline
\end{tabular}

The total emissions when assuming cane bagasse as a waste is $20.45 \mathrm{~kg} \mathrm{CO}_{2} \mathrm{eq} / \mathrm{metric}$ ton bagasse. The main GHG emission was transport, which was assumed to be $100 \mathrm{~km}$ and resulted in $16.80 \mathrm{~g} \mathrm{CO}_{2} \mathrm{eq} / \mathrm{kg}$ bagasse. Cumulative energy demand was also calculated for this waste scenario as shown in the Table 3.19. 
Table 3.19: CED for sugarcane bagasse when considering bagasse as a waste product with a basis of one MJ of sugarcane bagasse

\begin{tabular}{lc}
\hline Sugarcane Bagasse & MJ/MJ \\
\hline Non renewable fossil & $2.26 \mathrm{E}-02$ \\
Non renewable nuclear & $1.20 \mathrm{E}-03$ \\
Non renewable biomass & $6.49 \mathrm{E}-08$ \\
Renewable biomass & 1.00 \\
Renewable others & $1.05 \mathrm{E}-05$ \\
Renewable water & $2.31 \mathrm{E}-04$ \\
Total & 1.03 \\
\hline
\end{tabular}

The largest contributor to the CED is in renewable energy mainly the renewable biomass, which accounts for the inherent energy content of the bagasse. This renewable biomass was calculated using a LHV 13.66 GJ per metric ton (Table 1.2). Fossil fuels like diesel also contribute to the overall process while the balance contributes near negligible amounts.

The fossil energy is broken down into more detail in Table 3.20. The transport and diesel use contribute the most to the FED. The truck transport contributes the most to the total non renewable fossil energy used in this process. The rest of the inputs have negligible impact on the total fossil energy.

Table 3.20: FED for sugarcane bagasse when considered a waste with a basis of one MJ of bagasse

\begin{tabular}{lc}
\hline Fossil Energy Demand & MJ/MJ \\
\hline Transport truck & $2.24 \mathrm{E}-02$ \\
Diesel & $1.94 \mathrm{E}-03$ \\
Remaining & $1.28 \mathrm{E}-05$ \\
Total & $2.43 \mathrm{E}-02$ \\
\hline
\end{tabular}

\subsubsection{Corn Stover}

Similar to the cane bagasse study, we conducted a LCA study in SimaPro using the inventory data and assumptions from the CARB report (CARB 2009b) to generate the 
GHG emissions of ethanol production, assuming corn stover was a co-product. Corn stover was also considered a waste and inventory data from the Morey et al. report (Morey et al. 2010) was used to generate the GHG emission results. The system scope includes corn farming and harvesting, biomass transport and ethanol production. The results generated from SimaPro were then compared to the CARB study. An EPA 2012 projection scenario of the corn stover life cycle was also analyzed to compare the GHG results to the CARB study. The inventory data of corn farming and harvest were obtained directly from the FASOM model (EPA 2010b), which EPA used to conduct their study. The GHG emissions of corn stover collection and storage were obtained from the literature (Sokhansanj et al. 2010). Since land use change (LUC) has been identified as a potentially significant contributor to the environmental profile of biofuels, we also included the LUC impact of corn cultivation in our study (from RFS2).

The inventory data for corn farming and agricultural chemicals were obtained from both the CARB report and EPA study, and the GHG emissions of corn stover were generated in SimaPro. The GHG emissions of corn cultivation and harvest in the CARB report are in $\mathrm{g} \mathrm{CO}_{2}$ eq./MJ EtOH basis, and they were converted to per kg corn stover basis using ethanol yield, which is 2.72 and $2.62 \mathrm{gal} / \mathrm{bu}$ for dry mill and wet mill, respectively. The GHG emission of stover collection was obtained from a study conducted by Sokhansanj (Sokhansanj et al. 2010). The LUC impact of corn ethanol is listed in the CARB report as $30 \mathrm{~g} \mathrm{CO}_{2} \mathrm{eq} / \mathrm{MJ}$, and it was converted to gram per $\mathrm{kg}$ of corn stover basis as shown in equation 3.11. The GHG emissions results are shown in the Table 3.21 and Figure 3.8.

$\frac{30 \mathrm{~g} \mathrm{CO}_{2} \text { eq. }}{M J \text { of } \mathrm{EtOH}} * \frac{80.5 \mathrm{MJ} \text { of EtOH }}{1 \mathrm{gal} \mathrm{of} \mathrm{EtOH}} * \frac{2.72 \mathrm{gal} \mathrm{EtOH}}{56 \mathrm{lbs} \text { of corn }} * \frac{1 \mathrm{lb} \text { of corn }}{1 \mathrm{lb} \text { of corn stover }} * \frac{2.205 \mathrm{lbs}}{1 \mathrm{~kg}} * 0.5156=$ $133.38 \mathrm{~g} \mathrm{CO}_{2}$ eq. / $\mathrm{kg}$ of corn stover 
Table 3.21: GHG emissions of corn stover, comparing SimaPro simulation and CARB results

\begin{tabular}{lcccc}
\hline $\begin{array}{l}\text { g CO} \text { eq/kg corn } \\
\text { stover }\end{array}$ & $\begin{array}{c}\text { Corn stover } \\
\text { (CARB data) }\end{array}$ & $\begin{array}{c}\text { Corn stover } \\
\text { (EPA data) }\end{array}$ & $\begin{array}{c}\text { CARB } \\
\text { (dry mill) }\end{array}$ & $\begin{array}{c}\text { CARB } \\
\text { (wet mill) }\end{array}$ \\
\hline Corn farming & 24.21 & 17.90 & 25.12 & 24.88 \\
Ag chemicals & 112.99 & 56.79 & 134.27 & 134.26 \\
production and use & & & & \\
Stover collection & 6.7 & 6.7 & 6.7 & 6.7 \\
LUC & 133.38 & 133.38 & 133.38 & 128.48 \\
Total w/o LUC & 143.9 & 81.4 & 166.1 & 165.9 \\
Total w/ LUC & 277.28 & 214.77 & 299.48 & 294.32 \\
\hline
\end{tabular}

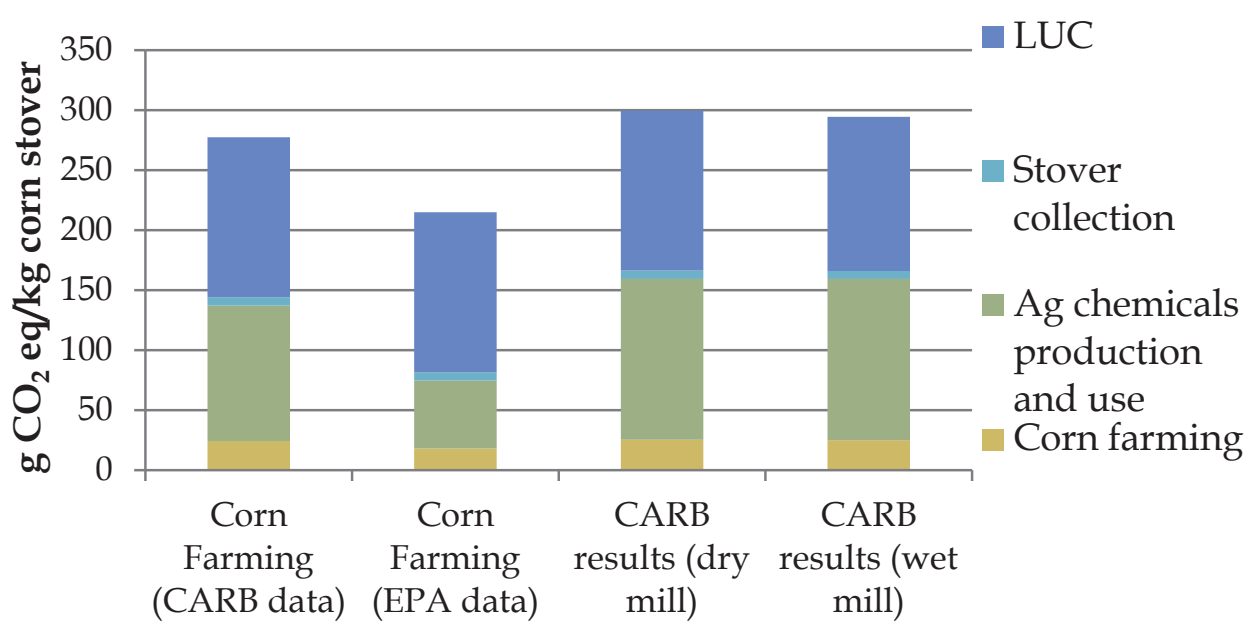

Figure 3.8: GHG emissions of corn stover, comparing SimaPro simulation and CARB results

The total GHG emissions from the SimaPro simulation using CARB data (left most bar in Figure 3.8) and the CARB results (right-most bars in Figure 3.8) are very consistent with each other. Agricultural chemicals production and use is a smaller contributor in the SimaPro simulation mainly because SimaPro uses a different GHG calculation method for fertilizer production. However, the results generated using the EPA data are much lower than the other three cases, mainly because the fertilizer and energy use in the EPA scenario is much less than in the CARB study. LUC is a major GHG contributor, accounting for approximately $50 \%$ of the total emissions for all cases. 
Kim and his research team published a paper in 2009 (Kim et al. 2009), presenting the corn stove GHG emissions results from their LCA study. The overall GHG emissions of corn stover ranged from -40 to $91 \mathrm{~g} \mathrm{CO}_{2} \mathrm{eq} / \mathrm{kg}$ stover, depending on different locations of the corn farms. However, their study used a displacement allocation approach to calculate the life cycle emissions, whereas our study uses an energy allocation approach. In the Kim and Dale (2009) study, there is a large $\mathrm{CO}_{2}$ credit given to the avoided grain emissions, because corn stover are collected from the farm, thus nitrogen related emissions from the soil due to stover decomposition (i.e., $\mathrm{N}_{2} \mathrm{O}, \mathrm{NOx}, \mathrm{NO}_{3}-$ ) are greatly reduced.

In the second scenario, stover was considered a waste and therefore assumed zero environmental burden. The only GHG contributions come from material collection, storage, and transport of the raw stover to the pyrolysis plant, which is shown in Table 3.22 below.

Table 3.22: GHG emissions of corn stover when considered a waste product in $\mathrm{kg} \mathrm{CO} 2$ eq/ metric ton corn stover

\begin{tabular}{lc}
\hline Corn Stover & kg $\mathrm{CO}_{2}$ eq. \\
\hline Transport & 4.86 \\
Fertilizer replenishment & 42.47 \\
Collection & 10.99 \\
Loading and unloading & 3.19 \\
Total & 61.52 \\
\hline
\end{tabular}

The total emissions when assuming corn stover as a waste is $61.52 \mathrm{~kg} \mathrm{CO}$ eq./metric ton of stover. The main GHG emission was fertilizer replenishment, which was needed since the stover acts as a source of fertilizer $\mathrm{N}, \mathrm{P}$, and $\mathrm{K}$ if left in the field. When stover is collected nutrients are lost and need to be replaced. We did not include any $\mathrm{N}_{2} \mathrm{O}$ emissions change when stover is removed because IPCC method does not distinguish between synthetic $\mathrm{N}$ and stover $\mathrm{N}$ with respect to $\mathrm{N}_{2} \mathrm{O}$ emissions. Fertilizer use results in 
nearly $70 \%$ of the total GHG emissions. The rest of the emissions only slightly impact the total emissions. CED was also calculated for this waste scenario as shown in Table 3.23.

Table 3.23: CED for corn stover when considering stover as a waste product with a basis of one MJ of corn stover

\begin{tabular}{lc}
\hline Cargill corn stover & MJ/MJ \\
\hline Non renewable fossil & $5.99 \mathrm{E}-02$ \\
Non renewable nuclear & $3.16 \mathrm{E}-03$ \\
Non renewable biomass & $3.24 \mathrm{E}-06$ \\
Renewable biomass & 1.00 \\
Renewable others & $5.55 \mathrm{E}-05$ \\
Renewable water & $5.45 \mathrm{E}-04$ \\
Total & 1.06 \\
\hline
\end{tabular}

The highest impact in the CED is in renewable energy mainly the renewable biomass, which accounts for the inherent energy content of the stover. This renewable biomass was calculated with a LHV 16.5 GJ per metric ton. Fossil fuels like diesel also contribute to the overall result while the rest have almost negligible amounts.

The non renewable fossil energy is broken down into more detail in Table 3.24. This shows that ammonia production, the major $\mathrm{N}$ fertilizer used, contributes the most the non renewable fossil energy use. Potassium and phosphate fertilizers as well as diesel and lubricating oil also contribute to the fossil energy in the production on corn stover.

Table 3.24: FED for corn stover when considered a waste with a basis of one MJ of corn stover

\begin{tabular}{ll}
\hline Fossil Energy Demand & MJ/MJ \\
\hline Ammonia & $2.32 \mathrm{E}-02$ \\
Diesel & $1.68 \mathrm{E}-02$ \\
Potassium sulfate & $1.63 \mathrm{E}-02$ \\
Diammonium phosphate & $3.33 \mathrm{E}-03$ \\
Lubricating oil & $1.62 \mathrm{E}-04$ \\
Total & $5.99 \mathrm{E}-02$ \\
\hline
\end{tabular}




\subsubsection{Waste Wood}

The waste wood LC GHG results are based on the inputs provided in the input section. Table 3.25 shows GHG emissions for the major waste wood production stages.

Table 3.25: Waste wood process stages and their corresponding GHG emissions with a basis of one dry metric ton.

\begin{tabular}{lc}
\hline Waste Wood Process & $\mathbf{k g ~ C O}$ eq. \\
\hline Collecting/Loading & 12.6 \\
Transportation & 6.4 \\
Unloading/Storage & 7.1 \\
Chipping \& Grinding & 4.0 \\
Total & 30.1 \\
\hline
\end{tabular}

The main GHG emissions were emitted during collecting/loading, which was $12.6 \mathrm{~kg}$ $\mathrm{CO}_{2}$ equivalent for every dry MT of waste wood. The chipping and grinding stage was the least significant. The main component in the chipping and grinding step was electricity because the main source of electricity in Washington State is from hydroelectricity. The GHG emission was low for this step.

Energy demand results are shown in Table 3.26 for Grays Harbor waste wood.

Table 3.26: Cumulative energy demand of the waste wood process with a basis of one MJ of waste wood.

\begin{tabular}{lc}
\hline Waste Wood Process & MJ/MJ \\
\hline Non Renewable, Fossil & $3.06 \mathrm{E}-02$ \\
Non renewable, nuclear & $7.78 \mathrm{E}-04$ \\
Non renewable, biomass & $5.11 \mathrm{E}-08$ \\
Renewable biomass & 1 \\
Renewable water & $1.25 \mathrm{E}-04$ \\
Renewable others & $1.07 \mathrm{E}-05$ \\
Total & 1.03 \\
\hline
\end{tabular}

The highest impact in the CED is in renewable energy, mainly the renewable biomass, which accounts for the inherent energy content of the waste wood. This renewable biomass was calculated with an assumed value of 20 GJ per metric ton. Fossil fuels like 
diesel also contribute to the overall process with $578 \mathrm{MJ} / \mathrm{MJ}$ while the rest have almost negligible amounts.

Fossil energy is broken down into more detail in Table 3.27. This breakdown shows that diesel consumption was the input that used the most fossil energy. Transport of the waste wood also contributed a significant amount, while machinery production and the chipper and grinder production contributed the least to the fossil energy demand for waste wood production.

Table 3.27: FED for waste wood process with a basis of one MJ of waste wood

\begin{tabular}{lc}
\hline Waste Wood Process & MJ/MJ \\
\hline Diesel & $2.33 \mathrm{E}-02$ \\
Transport & $6.77 \mathrm{E}-03$ \\
Machinery & $5.49 \mathrm{E}-04$ \\
Chopper & $2.01 \mathrm{E}-05$ \\
Total & $3.06 \mathrm{E}-02$ \\
\hline
\end{tabular}

\subsubsection{Guinea Grass}

The analysis of guinea grass used the inputs given in the input section to calculate GHG emissions. Two scenarios were developed to characterize the impact of vegetation removal (minimal or medium) and another scenario was developed based on unmanaged lands. Table 3.28 shows GHG emissions from the various production stages and for scenarios of minimal and medium prior vegetation as well as unmanaged lands. The unmanaged land only includes the harvest stage (Unmanaged land) and transport. 
Table 3.28: Guinea grass process stages assuming managed land and their corresponding GHG emissions with a basis of one dry metric ton

\begin{tabular}{lc}
\hline Guinea Grass (Tenbruggencate) Process & kg CO 2 eq./MT GG \\
\hline Land prep. minimal vegetation & 0.06 \\
Land prep. medium vegetation & 0.19 \\
Cultivation & 97.8 \\
Harvest (Managed Land) & 7.4 \\
Transport & 29.6 \\
Total & 135 \\
\hline
\end{tabular}

Table 3.29: Guinea grass process stages assuming unmanaged land and their corresponding GHG emissions with a basis of one dry metric ton

\begin{tabular}{lc}
\hline Guinea Grass (Tenbruggencate) Process & kg CO \\
\hline Land prep. minimal vegetation & 0.06 \\
Land prep. medium vegetation & 0.19 \\
Harvest (Unmanaged Lands) & 14.8 \\
Transport & 29.6 \\
Total (Unmanaged Land Scenario) & 44.4 \\
\hline
\end{tabular}

The calculation for the combustion of the diesel fuel needed for the guinea grass land preparation with medium vegetation is shown

$\frac{15 \mathrm{gal}}{\text { acre }} * \frac{1 \text { acre }}{60 \text { green } M T} * \frac{1 \text { green } M T}{0.80 \text { dry } M T} * \frac{3.785 \mathrm{~L}}{1 \mathrm{gal}} * \frac{0.85 \mathrm{~kg} \mathrm{diesel}}{1 \mathrm{~L}} * \frac{1}{20 \text { years }} * \frac{3.17 \mathrm{~kg} \mathrm{of} \mathrm{CO}_{2}}{1 \mathrm{~kg} \text { of diesel }}=$ $0.16 \frac{\mathrm{kg} \text { of } \mathrm{CO}_{2} \text { from diesel }}{1 \text { dry } \mathrm{MT}}$

where, 15 gal of diesel fuel per acre, $60 \mathrm{MT}$ of guinea grass per acre were given provided by Imperium and the $20 \%$ moisture content was from the elemental analysis of a harvested guinea grass sample as performed by Ensyn Technologies. The elemental analysis of guinea grass showed that 0.7 mass $\%$ was nitrogen on a dry basis. This value can be used to estimate $\mathrm{CO}_{2}$ and $\mathrm{N}_{2} \mathrm{O}$ emissions from the estimated urea application as shown in equation 3.13 . 


$$
\begin{aligned}
& \frac{0.007 \mathrm{~kg} \mathrm{of} \mathrm{N}}{1 \mathrm{~kg} \mathrm{of} \mathrm{GG}} * \frac{1000 \mathrm{~kg}}{1 \mathrm{MT}} * \frac{60 \mathrm{~kg} \text { of urea }}{28 \mathrm{~kg} \text { of } \mathrm{N}} * \frac{12 \mathrm{~kg} \mathrm{of} \mathrm{C}}{60 \mathrm{~kg} \text { of urea }} * \frac{44 \mathrm{~kg} \mathrm{of} \mathrm{CO}}{12 \mathrm{~kg} \mathrm{of} \mathrm{C}}= \\
& 11.00 \frac{\mathrm{kg} \mathrm{CO} \mathrm{O}_{2} \text { from urea }}{1 \mathrm{dryMT}}
\end{aligned}
$$

Guinea grass grown on managed land has a large GHG emission in the cultivation step primarily due to the use of fertilizers. The cultivation step accounted for $85.4 \mathrm{~kg} \mathrm{CO}_{2}$ equivalent for every dry MT of guinea grass. The land preparation and harvest stages contributed least to the overall process. The overall GHG emissions were 122 and $123 \mathrm{~kg}$ $\mathrm{CO}_{2}$ equivalent for every dry MT of guinea grass depending on the amount of tree removal required during the land preparation. Due to the lower yield, the harvest of unmanaged land had twice the GHG emission then compared to the managed land harvest step because twice the amount of fuel is being used to harvest the same amount of guinea grass. However, the overall GHG emission for this scenario was far less than the managed land scenarios. This was because only the harvest and transportation steps were needed, which resulted in a GHG emission of $44.4 \mathrm{~kg} \mathrm{CO}_{2}$ equivalent for every dry MT of guinea grass. This is most likely not a long lasting option since the nutrients in the soil will likely decrease over time, which will in turn lead to a drop in guinea grass yields.

Energy demand results for guinea grass are shown in Table 3.30.

Table 3.30: Average cumulative energy demand of the land preparation scenarios for guinea grass on managed lands with a basis of one MJ

\begin{tabular}{lc}
\hline Guinea Grass & MJ/MJ \\
\hline Non renewable, Fossil & $8.92 \mathrm{E}-02$ \\
Non renewable, nuclear & $5.65 \mathrm{E}-03$ \\
Non renewable, biomass & $1.49 \mathrm{E}-07$ \\
Renewable biomass & 1.00 \\
Renewable water & $1.01 \mathrm{E}-03$ \\
Renewable others & $8.5 \mathrm{E}-05$ \\
Total & 1.1 \\
\hline
\end{tabular}

The highest impact in the CED is the renewable biomass, which mainly accounts for the inherent energy content of the guinea grass. This renewable biomass was calculated with 
an assumed LHV value of $14.8 \mathrm{GJ}$ per metric ton. Fossil fuels like diesel also contribute to the overall process with $0.0892 \mathrm{MJ} / \mathrm{MJ}$ while the rest have almost negligible amounts.

The non renewable fossil energy for guinea grass is broken down into more detail in Table 3.31. This table shows transport by truck uses the most fossil energy in this analysis. Transport by barge, fertilizers, and diesel also contribute to the fossil energy used in the production of guinea grass.

Table 3.31: FED for guinea grass in Hawaii on managed land with a basis of one MJ of guinea grass

\begin{tabular}{lc}
\hline Fossil Energy Demand & MJ/MJ \\
\hline Urea & $2.96 \mathrm{E}-02$ \\
Transport truck & $1.67 \mathrm{E}-02$ \\
Potassium sulfate & $1.54 \mathrm{E}-02$ \\
Transport barge & $1.53 \mathrm{E}-02$ \\
Diesel & $6.55 \mathrm{E}-03$ \\
Thomas meal & $4.36 \mathrm{E}-03$ \\
Remaining & $1.29 \mathrm{E}-03$ \\
Total & 0.0892 \\
\hline
\end{tabular}




\section{Chapter 4 Inputs and Results for Stabilized PyOil Production}

\subsection{Inputs for Pretreatment, Pyrolysis, and Stabilization}

The inputs for pretreatment, pyrolysis, and stabilization for each feedstock are shown in Table A4.1 and Table A4.2 of appendix 4 including water inputs. Pyrolysis has inputs such as electricity and natural gas as well as a co-product of steam. Stabilization has inputs such as electricity and steam as well as ethanol as a flush solvent and a co-product of filter cake. Water is used during pyrolysis and stabilization process. This water exits the system as a spent brine waste stream. Figure 4.1 provides a simplified block flow diagram of the pretreatment, pyrolysis, and stabilization process. The inputs for each processing step are used in SimaPro 7.2 to calculate GHG emissions, CED/FED, and aggregated to estimate how much water is used in the overall process.

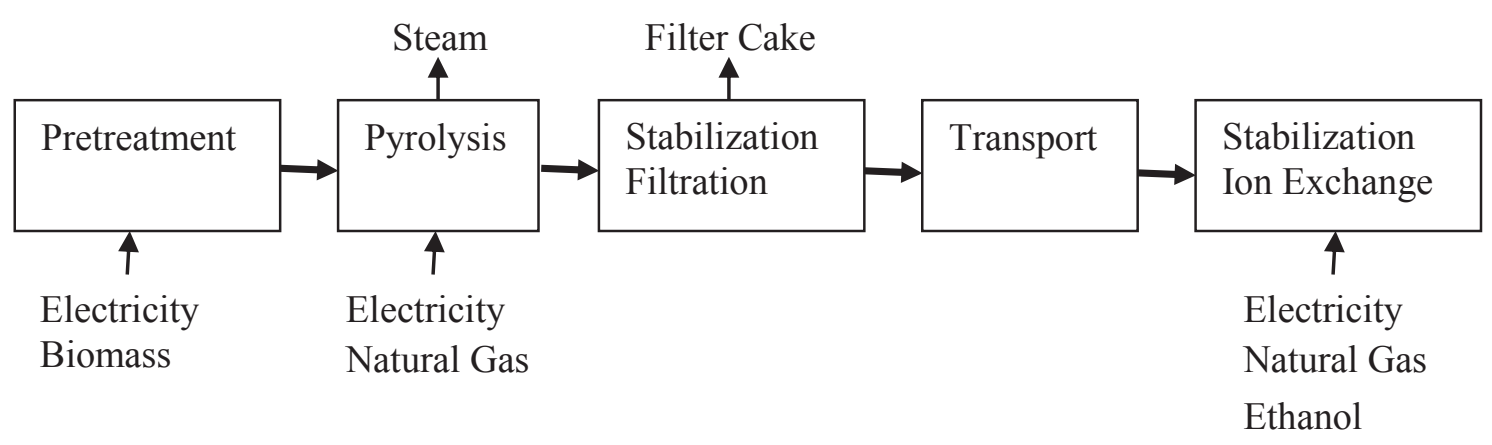

Figure 4.1: Process flow diagram for stabilized pyrolysis oil including significant inputs and co-products

\subsection{Results}

The inputs for pretreatment, pyrolysis, and stabilization provided by UOP are summarized in appendix 4. The same inputs were used to calculate GHG emissions using both displacement and energy allocation methodology. CED and FED results are shown 
for each feedstock. The results summarized in the immediately following sections of this report focus on displacement allocation.

\subsubsection{Albizia}

Inputs for pyrolysis and stabilization of albizia biomass were used to generate GHG emission results shown in Table 4.1. The results use displacement allocation in the first two columns and energy allocation in the last two columns. Results are expressed in units of $\mathrm{kg}$ of $\mathrm{CO}_{2}$ eq. per metric ton of stabilized pyrolysis oil and grams of $\mathrm{CO}_{2}$ eq. per MJ of stabilized pyrolysis oil. This scope of the analysis includes pretreatment, pyrolysis and stabilization of the pyrolysis oil. Stabilization is broken down into two steps, filtration and ion exchange. Albizia biomass, a raw material input to the pyrolysis step incorporates inputs from albizia production to arrive at this result. 
Table 4.1: GHG emissions (CO2 eq.) for stabilized pyrolysis oil derived from albizia using both displacement and energy allocation with functional units of metric tons of stabilized pyrolysis oil and MJ of stabilized pyrolysis oil

\begin{tabular}{|c|c|c|c|c|}
\hline Albizia & $\begin{array}{l}\mathrm{kg} / \mathrm{MT} \\
\text { (Dis) }\end{array}$ & $\begin{array}{l}\text { g/MJ } \\
\text { (Dis) }\end{array}$ & $\begin{array}{c}\mathrm{kg} / \mathrm{MT} \\
\text { (Spatari et al.) }\end{array}$ & $\begin{array}{c}\mathrm{g} / \mathbf{M J} \\
\text { (Spatari et al.) }\end{array}$ \\
\hline \multicolumn{5}{|l|}{ Pretreatment } \\
\hline Primary Sizing & 23.7 & 1.77 & 19.5 & 1.46 \\
\hline $\begin{array}{l}\text { Secondary Sizing \& } \\
\text { Handling }\end{array}$ & 19.8 & 1.48 & 16.3 & 1.22 \\
\hline Total & 43.5 & 3.25 & 35.8 & 2.67 \\
\hline \multicolumn{5}{|l|}{ Pyrolysis } \\
\hline \multicolumn{5}{|l|}{ Raw Materials } \\
\hline Albizia & 117 & 8.77 & 96.5 & 7.21 \\
\hline Sand & $1.26 \mathrm{E}-02$ & $9.43 \mathrm{E}-04$ & $1.04 \mathrm{E}-02$ & $7.75 \mathrm{E}-04$ \\
\hline Sand Transport & 0.10 & $7.57 \mathrm{E}-03$ & 8.33E-02 & $6.23 \mathrm{E}-03$ \\
\hline Total & 117 & 8.78 & 96.6 & 7.22 \\
\hline \multicolumn{5}{|l|}{ RTP Utilities } \\
\hline Natural Gas & $2.73 \mathrm{E}-02$ & 2.04E-03 & $2.24 \mathrm{E}-02$ & $1.68 \mathrm{E}-03$ \\
\hline Water & 4.06 & 0.30 & 3.34 & 0.25 \\
\hline Steam & -187 & -14.0 & & \\
\hline Air & 0.37 & $2.78 \mathrm{E}-02$ & 0.31 & $2.28 \mathrm{E}-02$ \\
\hline Electricity & 229 & 17.1 & 188 & 14.1 \\
\hline Total & 46.5 & 3.48 & 192 & 14.3 \\
\hline \multicolumn{5}{|l|}{ Waste Streams } \\
\hline Ash to landfill & 0.31 & $2.35 \mathrm{E}-02$ & 0.26 & $1.94 \mathrm{E}-02$ \\
\hline Total & 0.31 & $2.35 \mathrm{E}-02$ & 0.26 & $1.94 \mathrm{E}-02$ \\
\hline Pyrolysis Total & 208 & 15.5 & 324 & 24.2 \\
\hline \multicolumn{5}{|l|}{ Filtration } \\
\hline Pyrolysis Oil & 208 & 15.53 & 324 & 24.2 \\
\hline Filter cake & -96.2 & -7.19 & & \\
\hline Transportation & 19.1 & 1.42 & 18.0 & 1.35 \\
\hline Filtration Total & 131 & 9.77 & 342 & 25.6 \\
\hline \multicolumn{5}{|l|}{ Ion Exchange } \\
\hline \multicolumn{5}{|l|}{ Utilities } \\
\hline Electricity & 7.12E-02 & $5.32 \mathrm{E}-03$ & 7.12E-02 & $5.32 \mathrm{E}-03$ \\
\hline Steam & 0.26 & $1.97 \mathrm{E}-02$ & 0.26 & $1.97 \mathrm{E}-02$ \\
\hline Total & 0.34 & $2.51 \mathrm{E}-02$ & 0.34 & $2.51 \mathrm{E}-02$ \\
\hline \multicolumn{5}{|l|}{ Raw Materials } \\
\hline Filtered pyoil & 131.3 & 9.80 & 342.3 & 25.6 \\
\hline Ethanol & 33.4 & 2.50 & 33.4 & 2.50 \\
\hline Sulfuric Acid & 0.33 & $2.46 \mathrm{E}-02$ & 0.33 & $2.46 \mathrm{E}-02$ \\
\hline $\mathrm{NaOH}$ & 4.38 & 0.33 & 4.38 & 0.33 \\
\hline $\mathrm{NaCl}$ & 0.55 & 4.13E-02 & 0.55 & 4.13E-02 \\
\hline Rinse water & $9.24 \mathrm{E}-04$ & 6.91E-05 & $9.24 \mathrm{E}-04$ & 6.91E-05 \\
\hline
\end{tabular}




\begin{tabular}{lcccc}
\hline Total & 169 & 12.7 & 381 & 28.5 \\
Waste Streams & & & & \\
\hline Spent Brine & $2.61 \mathrm{E}-02$ & $1.95 \mathrm{E}-03$ & $2.61 \mathrm{E}-02$ & $1.95 \mathrm{E}-03$ \\
\hline Stabilized PyOil Total & 170 & 12.7 & 381 & 28.5 \\
\hline
\end{tabular}

The main contributor of GHG emissions shown in Table 4.1 is electricity use during pyrolysis, which accounts for $17.1 \mathrm{~g} / \mathrm{MJ}$. However, this is offset by a large steam credit produced during pyrolysis, which is $14.0 \mathrm{~g} / \mathrm{MJ}$. Another co-product during this process is filter cake which can be combusted to produce steam providing a GHG credit of 7.19 $\mathrm{g} / \mathrm{MJ}$ assuming it displaces coal used to produce steam. Corn ethanol is used as a flush solvent and contributes $2.50 \mathrm{~g} / \mathrm{MJ}$. In the downstream hydroprocessing step, the ethanol is converted to ethane which is in turn steam reformed to produce a portion of the required hydrogen. The entire process contributes $12.7 \mathrm{~g} / \mathrm{MJ}, 3.93 \mathrm{~g} / \mathrm{MJ}$ from pretreatment, pyrolysis, and stabilization. The balance of the GHG emissions occur during the production of the albizia biomass. Energy allocation results in higher GHG emissions than displacement allocation, consistent with what is normally observed in other biofuel life cycle assessments.

Table 4.2 shows the CED results for stabilized pyrolysis oil derived from albizia using displacement allocation. In order to produce one MJ of stabilized pyrolysis oil 2.44 MJ of renewable biomass energy and $0.114 \mathrm{MJ}$ of non renewable fossil energy is required. Minor amounts of energy derived from other sources are also included in Table 4.2. It is important that renewable energy contributes significantly to this process because that is one of the targeted advantage for this fuel compared to other existing fuels such as coal. 
Table 4.2: CED for stabilized pyrolysis oil derived from albizia using displacement allocation with a functional unit of one MJ of stabilized pyrolysis oil

\begin{tabular}{lc}
\hline Cumulative Energy Demand & MJ/MJ \\
\hline Non renewable fossil & 0.114 \\
Non renewable nuclear & $9.52 \mathrm{E}-02$ \\
Non renewable biomass & $6.13 \mathrm{E}-07$ \\
Renewable biomass & 2.44 \\
Renewable others & $4.81 \mathrm{E}-04$ \\
Renewable water & $9.1 \mathrm{E}-03$ \\
Total & 2.66 \\
\hline
\end{tabular}

Table 4.3 breaks down the non renewable fossil energy from Table 4.2 to determine what inputs consume the most fossil energy. Electricity use is the leading contributor of fossil energy at $0.239 \mathrm{MJ} / \mathrm{MJ}$. Diesel, transportation, and ethanol also contribute to the overall fossil energy use. The steam and filter cake co-products provide energy credits of 0.233 and 0.069 respectively. The total fossil energy used for this process is $0.114 \mathrm{MJ}$ per $\mathrm{MJ}$ of stabilized pyrolysis oil derived from albizia.

Table 4.3: FED for stabilized pyrolysis oil derived from albizia using displacement allocation with a functional unit of one MJ of stabilized pyrolysis oil

\begin{tabular}{lc}
\hline Fossil Energy Demand & MJ/MJ \\
\hline Electricity & 0.239 \\
Diesel & $6.05 \mathrm{E}-02$ \\
Truck transport & $5.17 \mathrm{E}-02$ \\
Barge transport & $2.68 \mathrm{E}-02$ \\
Ethanol & $2.52 \mathrm{E}-02$ \\
Filter Cake & $-6.9 \mathrm{E}-02$ \\
Steam Credit & -0.233 \\
Remaining & $1.31 \mathrm{E}-02$ \\
Total & 0.114 \\
\hline
\end{tabular}

\subsubsection{Feedstocks other than Albizia}

Inputs for pyrolysis and stabilization derived from each feedstock other than albizia were used to generate GHG emission results shown in Tables 4.4A and B. More detailed results are provided in Appendix 6. The results reflect displacement allocation with units 
of grams of $\mathrm{CO}_{2}$ eq. per $\mathrm{MJ}$ of stabilized pyrolysis oil. This analysis includes pretreatment, pyrolysis, and stabilization of the pyrolysis oil. Stabilization is broken down into two steps, filtration and ion exchange. Each feedstock is a raw material input during pyrolysis and therefore uses inputs from the corresponding feedstock production to arrive at this result.

Table 4.4A: GHG emissions (CO2 eq.) for stabilized pyrolysis oil using displacement allocation with a functional unit of one $\mathrm{MJ}$ of stabilized pyrolysis oil

\begin{tabular}{|c|c|c|c|c|}
\hline GHG Emissions & Bagasse & $\begin{array}{c}\text { Guinea } \\
\text { Grass }\end{array}$ & $\begin{array}{c}\text { Open Pond } \\
\text { Algae }\end{array}$ & $\begin{array}{l}\text { Corn } \\
\text { Stover }\end{array}$ \\
\hline Pretreatment & 1.85 & 2.32 & 2.56 & 2.18 \\
\hline \multicolumn{5}{|l|}{ RTP Raw Materials } \\
\hline Biomass feedstock & 1.38 & 12.3 & $\begin{array}{c}25.8 \\
20.7^{(1)}\end{array}$ & 6.36 \\
\hline Other raw materials & $3.14 \mathrm{E}-03$ & $3.81 \mathrm{E}-03$ & $3.67 \mathrm{E}-03$ & 4.09E-03 \\
\hline \multicolumn{5}{|l|}{ RTP Utilities } \\
\hline Steam Credit & -5.47 & -1.98 & -7.13 & -9.97 \\
\hline Electricity & 8.25 & 9.96 & 8.16 & 13.5 \\
\hline $\begin{array}{l}\text { Other (utilities and } \\
\text { waste treatment) }\end{array}$ & 0.20 & 0.32 & 0.20 & 0.40 \\
\hline \multicolumn{5}{|l|}{ PyOil Stabilization } \\
\hline Filter cake credit & -3.70 & -4.45 & -4.93 & -7.64 \\
\hline $\begin{array}{l}\text { Transportation of } \\
\text { filtered pyoil }\end{array}$ & 0.90 & 1.01 & 0.77 & 1.13 \\
\hline Steam & $1.35 \mathrm{E}-02$ & $3.98 \mathrm{E}-02$ & $1.46 \mathrm{E}-02$ & $1.76 \mathrm{E}-02$ \\
\hline Ethanol & 1.71 & 5.15 & 1.88 & 2.31 \\
\hline $\begin{array}{l}\text { Other (Materials, } \\
\text { Utilities, and Waste } \\
\text { Treatment) }\end{array}$ & 0.69 & 1.91 & 0.70 & 0.91 \\
\hline $\begin{array}{l}\text { Stabilized PyOil } \\
\text { Total }\end{array}$ & 5.82 & 26.6 & $\begin{array}{c}28.0 \\
22.9^{(1)} \\
\end{array}$ & 9.20 \\
\hline
\end{tabular}


Table 4.4B: Continuation of GHG emissions for stabilized pyrolysis oil using displacement allocation with a functional unit of one MJ of stabilized pyrolysis oil

\begin{tabular}{|c|c|c|c|c|}
\hline GHG Emissions & $\begin{array}{l}\text { LA Corn } \\
\text { Stover }\end{array}$ & Switchgrass & $\begin{array}{l}\text { Waste } \\
\text { Wood }\end{array}$ & $\begin{array}{l}\text { Wild } \\
\text { Algae }\end{array}$ \\
\hline Pretreatment & 2.27 & 2.68 & 2.60 & 2.55 \\
\hline \multicolumn{5}{|l|}{ RTP Raw Materials } \\
\hline Biomass feedstock & 6.40 & 12.03 & 4.05 & $\begin{array}{c}51.0 \\
-38.9^{(1)}\end{array}$ \\
\hline Other raw materials & $9.57 \mathrm{E}-03$ & $3.72 \mathrm{E}-03$ & 8.98E-03 & $3.69 \mathrm{E}-03$ \\
\hline \multicolumn{5}{|l|}{ RTP Utilities } \\
\hline Steam Credit & -20.5 & -9.1 & -15.1 & -2.33 \\
\hline Electricity & 15.8 & 11.6 & 16.2 & 8.64 \\
\hline $\begin{array}{l}\text { Other (utilities and } \\
\text { waste treatment) }\end{array}$ & 0.29 & 0.28 & 0.28 & 0.36 \\
\hline \multicolumn{5}{|l|}{ PyOil Stabilization } \\
\hline Filter cake credit & -6.51 & -5.04 & -5.35 & -8.09 \\
\hline $\begin{array}{l}\text { Transportation of } \\
\text { filtered pyoil }\end{array}$ & 1.22 & 1.18 & 1.15 & 0.72 \\
\hline Steam & $9.24 \mathrm{E}-03$ & $1.78 \mathrm{E}-02$ & $1.44 \mathrm{E}-02$ & 4.93E-02 \\
\hline Ethanol & 1.25 & 2.24 & 1.90 & 6.26 \\
\hline $\begin{array}{l}\text { Other (Materials, } \\
\text { Utilities, and Waste } \\
\text { Treatment) }\end{array}$ & 0.21 & 0.84 & 0.32 & 2.34 \\
\hline $\begin{array}{l}\text { Stabilized PyOil } \\
\text { Total }\end{array}$ & 0.45 & 16.7 & 6.07 & $\begin{array}{c}61.5 \\
-28.4^{(1)}\end{array}$ \\
\hline
\end{tabular}

${ }^{(1)}$ Wild Algae with waste water treatment credit

One of the largest contributors of GHG emissions is the RTP raw materials, in particular the biomass feedstock. Feedstocks that are considered waste products (waste wood, low ash corn stover, and sugarcane bagasse) that do not require fertilizer inputs have the lowest emissions. Feedstocks requiring fertilizer have higher GHG emission. Natural gas is used to produce fertilizers like urea, ammonium nitrate, etc. and a large amount of $\mathrm{CO}_{2}$ emissions are produced in this process. The largest contributor of GHG emissions to produce a biomass feedstock is wild algae. This is attributed to the large amount of water that needs to be processed and removed during the algae harvesting process. This process requires a large amount of electricity, which results in large GHG emissions. If wild algae is grown on waste water treatment effluent and a credit is taken for avoiding a separate denitrification step then the wild algae emissions are by far the lowest. 
Another large GHG emission is electricity. Stabilized pyrolysis oil derived from open pond algae has the highest lower heating value. This large lower heating value resulted in the lowest electricity emissions based on MJ of stabilized pyrolysis oil.

During the RTP process steam is generated by the excess heat that is produced in the reheat section of the pyrolysis. This steam credit was accounted for using displacement allocation as shown in Tables 4.4A and B. Energy allocation results are shown in Appendix 6. This steam credit has a significant impact on the total GHG emissions as shown in low ash corn stover case, where the calculated steam credit was $-20.5 \mathrm{~g} / \mathrm{MJ}$. Because of this large credit the total emissions for this process using low ash corn stover as the feedstock was $0.45 \mathrm{~g} / \mathrm{MJ}$. The larger total emissions for guinea grass feedstock, $26.6 \mathrm{~g} / \mathrm{MJ}$, is due to the large biomass and electricity inputs.

Tables 4.5A and B shows the CED results for stabilized pyrolysis oil derived from each feedstock using displacement allocation.

Table 4.5A: CED for stabilized pyrolysis oil using displacement allocation with a functional unit of one MJ of stabilized pyrolysis oil

\begin{tabular}{lcccc}
\hline \multicolumn{1}{c}{ CED (MJ/MJ) } & Bagasse & Guinea Grass & Open Pond Algae & Corn Stover \\
\hline $\begin{array}{l}\text { Non renewable } \\
\text { fossil }\end{array}$ & $5.52 \mathrm{E}-02$ & 0.279 & 0.472 & 0.100 \\
$\begin{array}{l}\text { Non renewable } \\
\text { nuclear }\end{array}$ & $5.05 \mathrm{E}-02$ & $7.86 \mathrm{E}-02$ & 0.154 & $7.92 \mathrm{E}-02$ \\
$\begin{array}{l}\text { Non renewable } \\
\text { biomass }\end{array}$ & $3.93 \mathrm{E}-07$ & $1.3 \mathrm{E}-06$ & $3.03 \mathrm{E}-05$ & $5.92 \mathrm{E}-06$ \\
$\begin{array}{l}\text { Renewable } \\
\text { biomass }\end{array}$ & 0.941 & 1.46 & 1.22 & 1.77 \\
$\begin{array}{l}\text { Renewable } \\
\text { others } \\
\text { Renewable water }\end{array}$ & $4.97 \mathrm{E}-03$ & $8.73 \mathrm{E}-03$ & $1.18 \mathrm{E}-03$ & $4.85 \mathrm{E}-04$ \\
\begin{tabular}{l} 
Total \\
\hline
\end{tabular} & 1.05 & 1.83 & $1.65 \mathrm{E}-02$ & $7.92 \mathrm{E}-03$ \\
\hline
\end{tabular}


Table 4.5B: Continuation of CED for stabilized pyrolysis oil using displacement allocation with a functional unit of one MJ of stabilized pyrolysis oil

\begin{tabular}{lcccc}
\hline CED (MJ/MJ) & LA Corn Stover & Switchgrass & Waste Wood & Wild Algae \\
\hline $\begin{array}{l}\text { Non renewable } \\
\text { fossil } \\
\text { Non renewable }\end{array}$ & $-5.03 \mathrm{E}-02$ & 0.135 & $2.01 \mathrm{E}-02$ & 0.932 \\
$\begin{array}{l}\text { nuclear } \\
\text { Non renewable } \\
\text { biomass }\end{array}$ & $7.78 \mathrm{E}-02$ & $7.75 \mathrm{E}-02$ & $8.44 \mathrm{E}-02$ & 0.260 \\
$\begin{array}{l}\text { Renewable } \\
\text { biomass }\end{array}$ & 1.65 & $1.08 \mathrm{E}-05$ & $3.51 \mathrm{E}-07$ & $1.54 \mathrm{E}-06$ \\
$\begin{array}{l}\text { Renewable } \\
\text { others }\end{array}$ & $3.93 \mathrm{E}-04$ & $4.85 \mathrm{E}-04$ & $3.98 \mathrm{E}-04$ & $1.54 \mathrm{E}-03$ \\
$\begin{array}{l}\text { Renewable } \\
\text { water }\end{array}$ & $7.35 \mathrm{E}-03$ & $8.59 \mathrm{E}-03$ & $7.82 \mathrm{E}-03$ & $2.48 \mathrm{E}-02$ \\
\hline \begin{tabular}{l} 
Total \\
\hline
\end{tabular} & 1.68 & 1.72 & 2.10 & 2.60 \\
\hline
\end{tabular}

In order to produce one $\mathrm{MJ}$ of stabilized pyrolysis oil 1.05 to $2.60 \mathrm{MJ}$ of energy is required. Biomass contributes the most energy as expected, because that is what the fuel is derived from. The remaining energy is used to process, transport, or stabilize the fuel. The higher energy demand is associated with fertilizers, and large electricity usage similar to the GHG results discussion on the previous page. It is important that renewable energy contributes significantly to this process because that is one of the targeted advantages to this fuel compared to fossil fuels such as coal.

Tables 4.6A and B below show the FED results for stabilized pyrolysis oil derived from each feedstock using displacement allocation.

Table 4.6A: FED for stabilized pyrolysis oil using displacement allocation with a functional unit of one MJ of stabilized pyrolysis oil

\begin{tabular}{lcccc}
\hline \multicolumn{1}{c}{ FED (MJ/MJ) } & Bagasse & Guinea Grass & OP Algae & Corn Stover \\
\hline Electricity & 0.119 & 0.144 & 0.319 & 0.184 \\
Truck Transport & $3.42 \mathrm{E}-02$ & $3.78 \mathrm{E}-02$ & $2.50 \mathrm{E}-02$ & $1.79 \mathrm{E}-02$ \\
Ethanol & $1.72 \mathrm{E}-02$ & $5.18 \mathrm{E}-02$ & $1.89 \mathrm{E}-02$ & $2.32 \mathrm{E}-02$ \\
Fertilizer & --- & $3.89 \mathrm{E}-02$ & 0.267 & $6.74 \mathrm{E}-02$ \\
Filter Cake & $-3.55 \mathrm{E}-02$ & $-4.26 \mathrm{E}-02$ & $-4.74 \mathrm{E}-02$ & $-7.33 \mathrm{E}-02$ \\
Steam Credit & $-9.13 \mathrm{E}-02$ & $-3.24 \mathrm{E}-02$ & -0.119 & -0.167 \\
Remaining & $1.14 \mathrm{E}-02$ & $8.2 \mathrm{E}-02$ & $1.01 \mathrm{E}-02$ & $4.78 \mathrm{E}-02$ \\
Total & $5.52 \mathrm{E}-02$ & 0.279 & 0.472 & 0.100 \\
\hline
\end{tabular}


Table 4.6B: Continuation of FED for stabilized pyrolysis oil using displacement allocation with a functional unit of one MJ of stabilized pyrolysis oil

\begin{tabular}{lcccc}
\hline \multicolumn{1}{c}{ FED (MJ/MJ) } & LA Corn Stover & Switchgrass & Waste Wood & Wild Algae \\
\hline Electricity & 0.199 & 0.167 & 0.220 & 0.591 \\
Truck Transport & $1.81 \mathrm{E}-02$ & $3.16 \mathrm{E}-02$ & $3.12 \mathrm{E}-02$ & $3.34 \mathrm{E}-02$ \\
Ethanol & $1.18 \mathrm{E}-02$ & $2.26 \mathrm{E}-02$ & $1.91 \mathrm{E}-02$ & $6.32 \mathrm{E}-02$ \\
Fertilizer & $6.92 \mathrm{E}-02$ & $2.39 \mathrm{E}-02$ & --- & $0.33^{(1)}$ \\
Filter Cake & $-5.89 \mathrm{E}-02$ & $-4.83 \mathrm{E}-02$ & $-5.13 \mathrm{E}-02$ & $-7.76 \mathrm{E}-02$ \\
Steam Credit & -0.322 & -0.151 & -0.252 & $-3.81 \mathrm{E}-02$ \\
Remaining & $3.24 \mathrm{E}-02$ & $8.96 \mathrm{E}-02$ & $5.33 \mathrm{E}-02$ & $3.00 \mathrm{E}-02$ \\
Total & $-5.03 \mathrm{E}-02$ & 0.135 & $2.01 \mathrm{E}-02$ & 0.932 \\
\hline
\end{tabular}

${ }^{(1)}$ This is chemical additives used during wild algae production

Electricity is one of the largest emissions contributing between 0.119 to $0.591 \mathrm{MJ} / \mathrm{MJ}$ for sugarcane bagasse and wild algae respectively. The electricity was used during the pretreatment and pyrolysis steps and the harvesting step for wild algae. Two co-products were produced, filter cake from filtering the pyrolysis oil, and steam produced from the excess heat generated in the RTP process. The credits from these co-products help minimize the net FED. The steam has the largest credit ranging between -0.0324 to $0.322 \mathrm{MJ} / \mathrm{MJ}$ for guinea grass and low ash corn stover respectively. Wild algae has the highest FED at $0.932 \mathrm{MJ} / \mathrm{MJ}$ because of the large amount of electricity and the amount of chemical additives used during the feedstock production stage. Low ash corn stover has a FED of $-0.0503 \mathrm{MJ} / \mathrm{MJ}$ because of the large amount of steam produced in this process. 


\section{Chapter 5: Inputs and Results for Hydrocarbon Biofuel Production}

\subsection{Inputs}

The inputs for upgrading stabilized pyrolysis oil for each feedstock are shown in Table A5.1 of Appendix 5. The main inputs are electricity and natural gas utilities and natural gas used to produce hydrogen for the process. There is a steam credit associated with hydrogen production and a steam credit during upgrading. There is cooling water and boiler feed water used in the upgrading process and de-mineralized water used in the integrated hydrogen process. Figure 5.1 shows a simplified block flow diagram of the upgrading process. These inputs are used in SimaPro 7.2 to calculate GHG emissions, $\mathrm{CED} / \mathrm{FED}$, and to show how much water is used in the process.

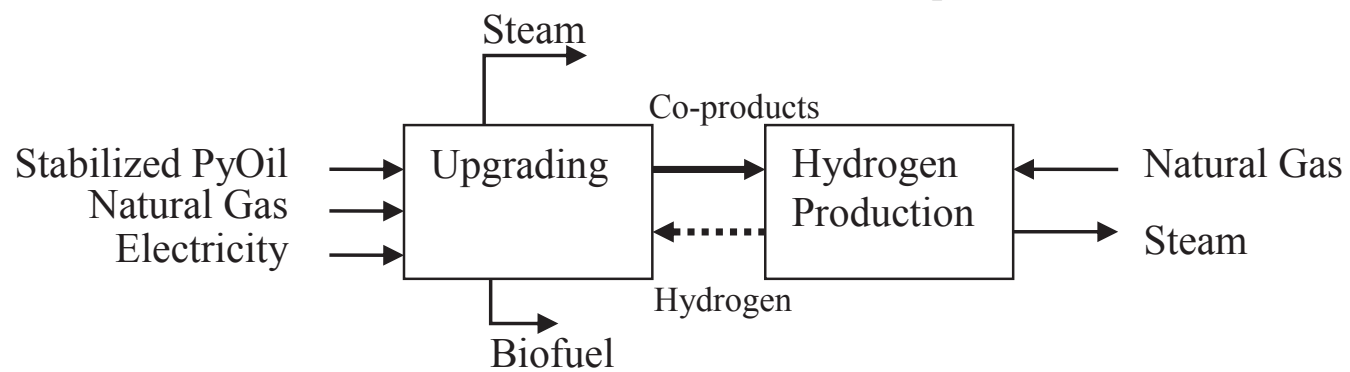

Figure 5.1: Simplified Block flow diagram of the upgrading process

Transportation inputs of petroleum products to consumer from the NETL report (NETL 2008) were used to estimate the transportation inputs for the Biofuels generated in this process. Each biofuel needs to be transported to gas stations for consumer use. The inputs in Table 5.6 from the NETL report were used in this study for transporting biofuel to the consumer.

\subsection{Results}

Inputs supplied by UOP as shown in Appendix 5, were used to calculate GHG emissions for each biomass feedstock using displacement and energy allocation. CED and FED results were also calculated for each feedstock. The results that are discussed use displacement allocation and the functional unit is $1 \mathrm{MJ}$ of biofuel. 


\subsubsection{Albizia}

Inputs for upgrading stabilized pyrolysis bio-oil derived from albizia were used to generate the GHG emission results shown in Table 5.1. The results for displacement allocation are in the first two columns and the results for energy allocation in the last two columns. Each allocation method shows results in both $\mathrm{kg}$ of $\mathrm{CO}_{2}$ eq. per metric ton of biofuels and grams of $\mathrm{CO}_{2}$ eq. per MJ of biofuel. The feedstock production, pyrolysis and stabilization results are shown in the first three rows and the upgrading results are broken down into more detail in the latter rows.

Table 5.1: GHG emissions (CO2 eq.) for biofuel derived from albizia for both displacement (Dis) and energy allocation (Spatari et al.) with two functional units of metric tons of biofuel and MJ of biofuel.

\begin{tabular}{lcccc}
\hline Albizia Results & $\begin{array}{c}\mathbf{k g} / \mathbf{M T} \\
\text { (Dis) }\end{array}$ & $\begin{array}{c}\text { g/MJ } \\
\text { (Dis) }\end{array}$ & $\begin{array}{c}\mathbf{k g} / \mathbf{M T} \\
\text { (Spatari et al.) }\end{array}$ & $\begin{array}{c}\text { g/MJ } \\
\text { (Spatari et al.) }\end{array}$ \\
\hline Feedstock Production & 360 & 8.37 & 237 & 5.51 \\
$\begin{array}{l}\text { Pyrolysis } \\
\text { Stabilization }\end{array}$ & 277 & 6.45 & 559 & 13.01 \\
Upgrading & -117 & -2.72 & 140 & 3.26 \\
Raw material & & & & \\
Stabilized pyoil & 520 & 12.10 & 936 & 21.8 \\
Effluents & & & & \\
Wastewater & 0.61 & $1.42 \mathrm{E}-02$ & 0.49 & $1.14 \mathrm{E}-02$ \\
Utilities & & & & \\
Electricity & 181 & 4.21 & 145 & 3.37 \\
$\begin{array}{l}\text { Natural gas } \\
\text { Water }\end{array}$ & 101 & 2.35 & 80.9 & 1.88 \\
Steam & 0.63 & $1.47 \mathrm{E}-02$ & 0.51 & $1.18 \mathrm{E}-02$ \\
Solid waste & -202 & -4.70 & & \\
Integrated $\mathrm{H}_{2}$ Plant & $1.11 \mathrm{E}-02$ & $2.58 \mathrm{E}-04$ & $8.89 \mathrm{E}-03$ & $2.07 \mathrm{E}-04$ \\
$\begin{array}{l}\text { Natural gas } \\
\text { Demineralized water }\end{array}$ & 1050 & 24.4 & & \\
HP steam & $9.73 \mathrm{E}-02$ & $2.26 \mathrm{E}-03$ & $7.79 \mathrm{E}-02$ & $1.81 \mathrm{E}-03$ \\
$\begin{array}{l}\text { Electricity } \\
\text { Transportation }\end{array}$ & -581 & -13.5 & & \\
Overall Total & 54.2 & 1.26 & 43.4 & 1.01 \\
\hline & 8.86 & 0.21 & 7.10 & 0.17 \\
\hline
\end{tabular}


The main contributor of GHG emissions is the natural gas used to produce hydrogen. When looking at the results for displacement allocation, the natural gas used in upgrading utilities and in integrated $\mathrm{H}_{2}$ production contributes $92 \%$ of the total $\mathrm{GHG}$ emissions for the entire process. There is also a large credit of high pressure $(\mathrm{HP})$ steam $(13.5 \mathrm{~g} / \mathrm{MJ})$ in the integrated hydrogen process, which reduces the overall GHG emissions significantly. Another important result is the electricity use, which contributes $4.21 \mathrm{~g} / \mathrm{MJ}$ during upgrading. Steam is also produced during upgrading step and a credit of $4.70 \mathrm{~g} / \mathrm{MJ}$ is associated with this co-product. Conventional non-renewable gasoline contributes 90.12 $\mathrm{g} / \mathrm{MJ}$, while the albizia derived biofuel contributes $26.4 \mathrm{~g} / \mathrm{MJ}$, which is a $70.7 \% \mathrm{GHG}$ savings.

Table 5.2 shows the CED results for this biofuel. Renewable biomass contributes $2.33 \mathrm{MJ}$ of energy to produce one MJ of biofuel, and in which fossil fuels contribute $0.333 \mathrm{MJ}$ to produce one MJ of biofuels. This is important because renewable fuels should contribute the most energy to this process otherwise there would be no reason to switch from fossil fuels to this biofuels derived from albizia.

Table 5.2: CED for biofuel derived from albizia using displacement allocation with a functional unit of one MJ of biofuel

\begin{tabular}{lc}
\hline Cumulative Energy Demand & MJ/MJ \\
\hline Non renewable fossil & 0.333 \\
Non renewable nuclear & 0.12 \\
Non renewable biomass & $7.57 \mathrm{E}-07$ \\
Renewable biomass & 2.33 \\
Renewable others & $6.86 \mathrm{E}-04$ \\
Renewable water & $1.17 \mathrm{E}-02$ \\
Total & 2.8 \\
\hline
\end{tabular}

Table 5.3 breaks down the non renewable fossil energy to determine what inputs use the most fossil energy. This table shows that natural gas is the leading contributor of fossil energy. Natural gas contributes $0.461 \mathrm{MJ}$ of energy per MJ of biofuels. However, this natural gas not only produces hydrogen for the process but also produces steam. Excess steam has a credit of $0.527 \mathrm{MJ}$ of energy per MJ of biofuels, which more than offsets the 
fossil energy from natural gas. The fossil energy portion is $0.333 \mathrm{MJ}$ per MJ of biofuels derived from albizia.

Table 5.3: FED for biofuel derived from albizia using displacement allocation with a functional unit of one MJ of biofuel

\begin{tabular}{lc}
\hline Fossil Energy Demand & MJ/MJ \\
\hline Natural gas & 0.461 \\
Electricity & 0.292 \\
Diesel & $5.77 \mathrm{E}-02$ \\
Truck transport & $4.93 \mathrm{E}-02$ \\
Barge transport & $2.56 \mathrm{E}-02$ \\
Ethanol & $2.4 \mathrm{E}-02$ \\
Filter cake & $-6.57 \mathrm{E}-02$ \\
Steam credit & -0.527 \\
Remaining & $1.55 \mathrm{E}-02$ \\
Total & 0.333 \\
\hline
\end{tabular}

\subsubsection{Feedstocks Excluding Albizia}

Inputs for upgrading stabilized pyrolysis oil derived from each feedstock other than albizia were used to generate GHG emission results shown in Tables 5.4A and B. More detailed results are shown in Appendix 6. The results in these tables are for displacement allocation with units of grams of $\mathrm{CO}_{2}$ eq. per MJ of upgraded pyrolysis oil. The upgrading step is split into two stages, the integrated hydrogen plant and the upgrading step. The integrated hydrogen step uses steam methane reforming to produce hydrogen from the $\mathrm{HC}$ gases produced in the upgrading reaction as well as from imported natural gas. The hydrogen is then reacted with the stabilized pyrolysis oil to form upgraded pyrolysis oil, which is the final biofuel product. 
Table 5.4A: GHG emissions (g CO2 eq/MJ) for upgraded pyrolysis oil using displacement allocation with a functional unit of one $\mathrm{MJ}$ of upgraded pyrolysis oil

\begin{tabular}{|c|c|c|c|c|}
\hline Results & Bagasse & $\begin{array}{c}\text { Guinea } \\
\text { Grass }\end{array}$ & $\begin{array}{c}\text { Open Pond } \\
\text { Algae }\end{array}$ & $\begin{array}{c}\text { Corn } \\
\text { Stover }\end{array}$ \\
\hline $\begin{array}{l}\text { Feedstock } \\
\text { Production }\end{array}$ & 1.55 & 14.1 & $30.4 / 24.5^{(1)}$ & 6.63 \\
\hline Pyrolysis & 5.41 & 12.1 & 4.47 & 6.36 \\
\hline Stabilization & -0.45 & 4.19 & -1.85 & -3.41 \\
\hline \multicolumn{5}{|l|}{ Upgrading } \\
\hline Steam credit & -3.49 & -4.09 & -3.16 & -4.09 \\
\hline Electricity & 3.12 & 3.67 & 2.81 & 3.67 \\
\hline Natural gas & 1.75 & 2.07 & 1.58 & 2.06 \\
\hline $\begin{array}{l}\text { Other (Materials, } \\
\text { Utilities, waste) }\end{array}$ & $\begin{array}{l}1.11 \mathrm{E}- \\
02\end{array}$ & $1.30 \mathrm{E}-02$ & $9.98 \mathrm{E}-03$ & $1.30 \mathrm{E}-02$ \\
\hline \multicolumn{5}{|l|}{ Integrated $\mathrm{H}_{2}$ Plant } \\
\hline Natural gas & 11.2 & 13.9 & 10.3 & 19.0 \\
\hline Steam credit & -9.49 & -11.8 & -9.49 & -11.2 \\
\hline $\begin{array}{l}\text { Other (Materials, } \\
\text { Utilities) }\end{array}$ & 1.10 & 1.31 & 1.10 & 1.25 \\
\hline Biofuel Total & 10.7 & 35.5 & $36.2 / 30.2^{(1)}$ & 20.3 \\
\hline
\end{tabular}

${ }^{(1)}$ Nutrient recycle 
Table 5.4B: GHG emissions ( $\mathrm{g} \mathrm{CO} 2 \mathrm{eq} / \mathrm{MJ}$ ) continued for upgraded pyrolysis oil using displacement allocation with a functional unit of one MJ of upgraded pyrolysis oil

\begin{tabular}{lcccc}
\hline \multicolumn{1}{c}{ Results } & $\begin{array}{c}\text { Low Ash (LA) } \\
\text { Corn Stover }\end{array}$ & Switchgrass & $\begin{array}{c}\text { Waste } \\
\text { Wood }\end{array}$ & $\begin{array}{c}\text { Wild } \\
\text { Algae }\end{array}$ \\
\hline $\begin{array}{l}\text { Feedstock } \\
\text { Production }\end{array}$ & 6.73 & 11.9 & 4.08 & $66.4 /-$ \\
Pyrolysis & -2.23 & 5.36 & 3.97 & $50.7^{(1)}$ \\
Stabilization & -4.04 & -0.76 & -1.99 & 12.0 \\
Upgrading & -4.37 & -4.02 & -3.98 & -3.49 \\
Steam credit & 3.93 & 3.60 & 3.56 & 3.09 \\
Electricity & 2.20 & 2.02 & 2.00 & 1.74 \\
Natural gas & $2.65 \mathrm{E}-02$ & $2.34 \mathrm{E}-02$ & 0.13 & $1.59 \mathrm{E}-02$ \\
$\begin{array}{l}\text { Other (Materials, } \\
\text { Utilities, waste) }\end{array}$ & & & & \\
Integrated H2 Plant & 25.8 & 27.7 & 21.6 & 2.65 \\
$\begin{array}{l}\text { Natural gas } \\
\text { Steam credit }\end{array}$ & -12.0 & -12.8 & -11.4 & -11.0 \\
$\begin{array}{l}\text { Other (Materials, } \\
\text { Utilities) }\end{array}$ & 1.33 & 1.40 & 1.28 & 1.23 \\
Biofuel Total & 17.4 & 34.4 & 19.3 & $74.3 /$ \\
\hline Wastewater treatment & & & $-42.8^{(1)}$ \\
\hline
\end{tabular}

${ }^{(1)}$ Wastewater treatment Credit

Feedstock production, pyrolysis, and stabilization process steps are discussed in more detail in Chapters 3 and 4. Feedstock production was dominated by fertilizer and electricity use, which cause GHG emission to increase. Pyrolysis and stabilization emissions were controlled primarily by the electricity use and co-product credits. Upgrading emissions were dominated by natural gas used to generate hydrogen in the integrated hydrogen plant. Steam credits also play a significant role in the final GHG emissions.

Natural gas usage depends on the amount of co-product produced in the upgrading step. The more $\mathrm{HC}$ gas produce as a co-product the less natural gas is required to generate hydrogen. GHG emission from steam reforming of natural gas range from 2.65 to 27.7 $\mathrm{g} / \mathrm{MJ}$ from biofuels derived from wild algae and switchgrass, respectively. 
The amount of steam that is produced during upgrading and resulting from methane steam reforming are similar between each feedstock biofuel, but does significantly reduce the overall emissions. The steam credit is the largest in the integrated hydrogen plant with the credit of GHG emission from switchgrass derived biofuel at -12.8 g/MJ. The largest steam credit from upgrading is $-4.37 \mathrm{~g} / \mathrm{MJ}$ from low ash corn stover derived biofuel.

Tables 5.5A and B show the CED results for each biofuel derived from each feedstock excluding albizia using displacement allocation.

Table 5.5A: CED for upgraded pyrolysis oil using displacement allocation with a functional unit of one MJ of upgraded pyrolysis oil

\begin{tabular}{lcccc}
\hline CED (MJ/MJ) & Bagasse & Guinea Grass & $\begin{array}{c}\text { Open Pond } \\
\text { Algae }\end{array}$ & $\begin{array}{c}\text { Corn } \\
\text { Stover }\end{array}$ \\
\hline $\begin{array}{l}\text { Non renewable } \\
\text { fossil }\end{array}$ & 0.118 & 0.388 & 0.596 & 0.271 \\
$\begin{array}{l}\text { Non renewable } \\
\text { nuclear }\end{array}$ & $7.62 \mathrm{E}-02$ & 0.113 & 0.20 & 0.108 \\
$\begin{array}{l}\text { Non renewable } \\
\text { biomass }\end{array}$ & $4.96 \mathrm{E}-07$ & $1.48 \mathrm{E}-06$ & $3.58 \mathrm{E}-05$ & $6.32 \mathrm{E}-06$ \\
$\begin{array}{l}\text { Renewable } \\
\text { biomass }\end{array}$ & 1.05 & 1.67 & 1.44 & 1.85 \\
$\begin{array}{l}\text { Renewable } \\
\text { others }\end{array}$ & $4.49 \mathrm{E}-04$ & $8.63 \mathrm{E}-04$ & $1.51 \mathrm{E}-03$ & $6.92 \mathrm{E}-04$ \\
$\begin{array}{l}\text { Renewable } \\
\text { water }\end{array}$ & $7.45 \mathrm{E}-03$ & $1.22 \mathrm{E}-02$ & $2.12 \mathrm{E}-02$ & $1.08 \mathrm{E}-02$ \\
Total & 1.25 & 2.18 & 2.26 & 2.24 \\
\hline
\end{tabular}


Table 5.5B: CED (continued) for upgraded pyrolysis oil using displacement allocation with a functional unit of one MJ of upgraded pyrolysis oil

\begin{tabular}{lcccc}
\hline CED (MJ/MJ) & $\begin{array}{c}\text { LA Corn } \\
\text { Stover }\end{array}$ & Switchgrass & Waste Wood & Wild Algae \\
\hline $\begin{array}{l}\text { Non renewable } \\
\text { fossil }\end{array}$ & 0.219 & 0.426 & 0.227 & 1.1 \\
$\begin{array}{l}\text { Non renewable } \\
\text { nuclear }\end{array}$ & 0.115 & 0.104 & 0.111 & 0.355 \\
$\begin{array}{l}\text { Non renewable } \\
\text { biomass }\end{array}$ & $6.02 \mathrm{E}-06$ & $1.09 \mathrm{E}-05$ & $5.24 \mathrm{E}-07$ & $1.91 \mathrm{E}-06$ \\
$\begin{array}{l}\text { Renewable } \\
\text { biomass }\end{array}$ & 1.84 & 1.48 & 2.00 & 1.79 \\
$\begin{array}{l}\text { Renewable } \\
\text { others }\end{array}$ & $6.62 \mathrm{E}-04$ & $7.14 \mathrm{E}-04$ & $6.02 \mathrm{E}-04$ & $2.08 \mathrm{E}-03$ \\
$\begin{array}{l}\text { Renewable } \\
\text { water }\end{array}$ & $1.12 \mathrm{E}-02$ & $1.15 \mathrm{E}-02$ & $1.06 \mathrm{E}-02$ & $3.37 \mathrm{E}-02$ \\
Total & 2.14 & 2.03 & 2.35 & 3.28 \\
\hline
\end{tabular}

In order to produce one $\mathrm{MJ}$ of biofuel 1.25 to $3.28 \mathrm{MJ}$ of energy is required, depending on biomass type. Biomass energy contributes the most energy as expected, because that is what the fuel is derived from. The remaining energy is used to process, transport, or stabilize the fuel. The higher energy demand is associated with fertilizers and electricity usage. The energy associated with fertilizer production is shown mostly in non renewable fossil energy because most fertilizers are derived from fossil fuels like natural gas.

Electricity assumes the U.S. grid electricity, which uses most of the energy sources but is dominated by non renewable fossil energy

Tables 5.6A and B show the FED results for biofuels derived from each feedstock other than albizia using displacement allocation. 
Table 5.6A: FED for upgraded pyrolysis oil using displacement allocation with a functional unit of one MJ of upgraded pyrolysis oil

\begin{tabular}{lcccc}
\hline FED $(\mathbf{M J} / \mathbf{M J})$ & Bagasse & $\begin{array}{c}\text { Guinea } \\
\text { Grass }\end{array}$ & $\begin{array}{c}\text { Open Pond } \\
\text { Algae }\end{array}$ & $\begin{array}{c}\text { Corn } \\
\text { Stover }\end{array}$ \\
\hline Natural Gas & 0.224 & 0.276 & 0.204 & 0.363 \\
Electricity & 0.18 & 0.22 & 0.419 & 0.247 \\
Truck transport & $3.81 \mathrm{E}-02$ & $4.32 \mathrm{E}-02$ & $3.03 \mathrm{E}-02$ & $1.87 \mathrm{E}-02$ \\
Fertilizer & --- & $4.44 \mathrm{E}-02$ & 0.314 & $7.03 \mathrm{E}-02$ \\
Ethanol & $1.92 \mathrm{E}-02$ & $5.91 \mathrm{E}-02$ & $2.23 \mathrm{E}-02$ & $2.42 \mathrm{E}-02$ \\
Filter cake & $-3.96 \mathrm{E}-02$ & $-4.87 \mathrm{E}-02$ & $-5.59 \mathrm{E}-02$ & $-7.64 \mathrm{E}-02$ \\
Steam credit & -0.319 & -0.303 & -0.352 & -0.429 \\
Remaining & $1.57 \mathrm{E}-02$ & $9.67 \mathrm{E}-02$ & $1.41 \mathrm{E}-02$ & $5.29 \mathrm{E}-02$ \\
Total & 0.118 & 0.388 & 0.596 & 0.271 \\
\hline
\end{tabular}

Table 5.6B: FED continued for upgraded pyrolysis oil using displacement allocation with a functional unit of one MJ of upgraded pyrolysis oil

\begin{tabular}{lcccc}
\hline \multicolumn{1}{c}{ FED (MJ/MJ) } & $\begin{array}{c}\text { LA Corn } \\
\text { Stover }\end{array}$ & Switchgrass & $\begin{array}{c}\text { Waste } \\
\text { Wood }\end{array}$ & $\begin{array}{c}\text { Wild } \\
\text { Algae }\end{array}$ \\
\hline Natural gas & 0.483 & 0.514 & 0.407 & $7.57 \mathrm{E}-02$ \\
Electricity & 0.281 & 0.221 & 0.275 & 0.817 \\
Truck transport & $2.02 \mathrm{E}-02$ & $3.12 \mathrm{E}-02$ & $3.13 \mathrm{E}-02$ & $4.43 \mathrm{E}-02$ \\
Ethanol & $1.32 \mathrm{E}-02$ & $2.23 \mathrm{E}-02$ & $1.92 \mathrm{E}-02$ & $8.22 \mathrm{E}-02$ \\
Fertilizer & $7.13 \mathrm{E}-02$ & $3.25 \mathrm{E}-02$ & --- & $0.429(1)$ \\
Filter cake & $-6.58 \mathrm{E}-02$ & $-4.77 \mathrm{E}-02$ & $-5.16 \mathrm{E}-02$ & -0.101 \\
Steam credit & -0.633 & -0.43 & -0.511 & -0.291 \\
Remaining & $4.54 \mathrm{E}-02$ & $8.25 \mathrm{E}-02$ & $5.77 \mathrm{E}-02$ & $4.11 \mathrm{E}-02$ \\
Total & 0.215 & 0.426 & 0.227 & 1.10 \\
\hline
\end{tabular}

(1) This is chemical additives used during wild algae production

Natural gas and electricity are the largest fossil energy inputs for each biofuel. The electricity FED is the largest in the wild and open pond algae because of the large electricity inputs during feedstock production. Natural gas FED is the largest in the remaining biofuels because of the large input used to generate hydrogen. The natural gas contributes between 0.0757 to $0.514 \mathrm{MJ} / \mathrm{MJ}$ for wild algae and swithchgrass respectively. Two co-products are produced; filter cake from filtering the pyrolysis oil, and steam produce by the excess heat during pyrolysis. These co-products help minimize the FED. The steam has the largest credit ranging between -0.633 to $-0.291 \mathrm{MJ} / \mathrm{MJ}$ for low ash corn stover and wild algae respectively. Wild algae has the highest FED at 1.10 MJ/MJ because of the large amount of electricity and natural gas use. Sugarcane bagasse has the 
lowest FED of $0.118 \mathrm{MJ} / \mathrm{MJ}$ because of the large amount of steam produced in this process and the low amount of natural gas and electricity required. 


\section{Chapter 6 LCA Summary, Conclusions and Recommendations}

\subsection{Summary and Conclusions}

\subsubsection{Feedstock Production}

The feedstocks analyzed in this study covered a wide range of types; residues from agriculture and forests, energy crops such as switchgrass and managed guinea grass, and algae. The biomass types that released the least amount of GHG emissions were feedstocks that are considered waste products as shown in Figure 6.1. The figures in chapter 6 were developed from the results in chapter 5 . The different scenarios, including nutrient recycle and waste water treatment, were not included in these figures.

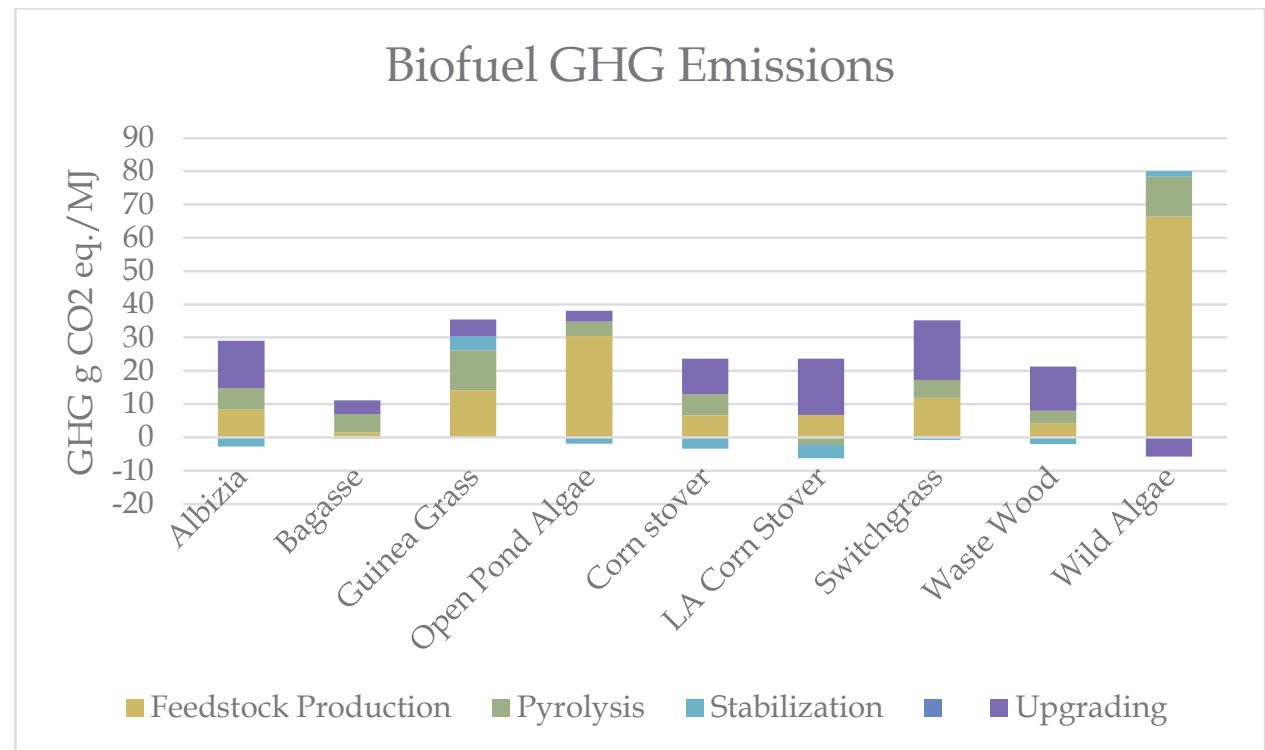

Figure 6.1 GHG emissions showing each stage of each biofuel with a functional unit of 1 MJ of biofuel for displacement allocation 
Feedstocks like sugarcane bagasse and waste wood had no fertilizer inputs, which greatly increase the GHG emissions as well as the fossil energy demand as shown in Figure 6.2. Sugarcane bagasse was the best feedstock because after sugar is extracted from sugarcane the bagasse is left. This is why sugarcane bagasse emits a low amount of GHGs. There is no cultivation, which includes fertilizers, no harvest, which uses diesel and no collection of the biomass because the sugarcane was collected for sugar production, not for biofuel.

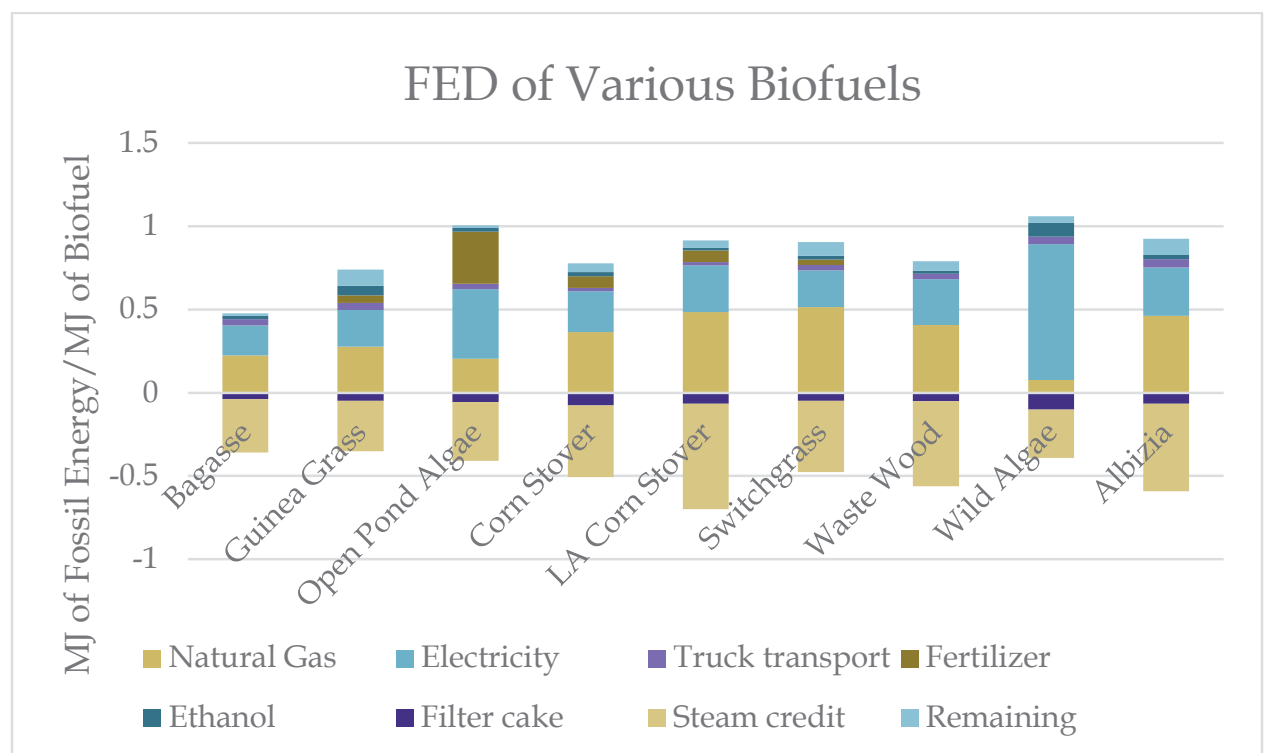

Figure 6.2 FED of each biofuel with a functional unit of one MJ of Biofuel for displacement allocation

Waste wood is similar to bagasse but waste wood needs to be collected and chipping and grinding is required, which increases the GHG emissions, FED, and CED which is shown in Figure 6.3. Both algae cases have the highest GHG emissions due to large electricity inputs used to pump, and dewater the algae. However, if algae were cultivated as part of wastewater treatment, a large energy and GHG emission credit for avoiding a nutrient removal step may be warranted and could make algae a promising feedstock. 


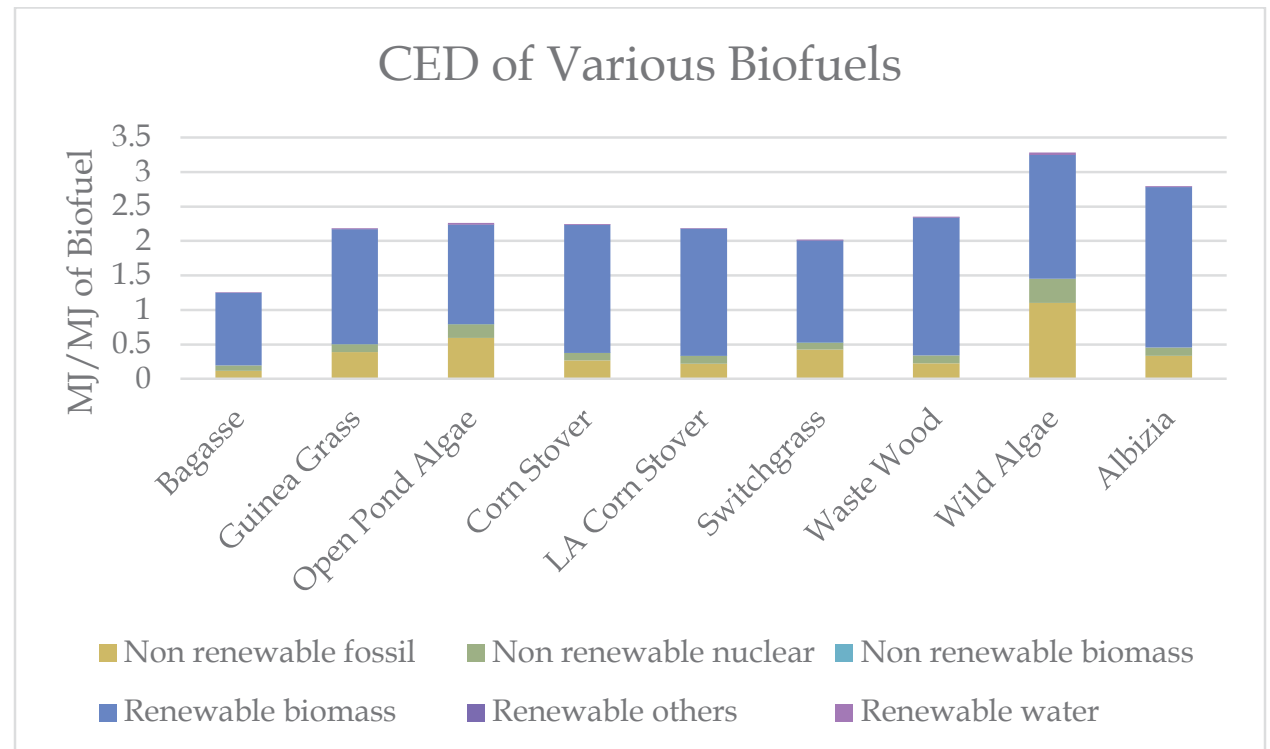

Figure 6.3 Total CED for each biofuel with a function unit of one MJ for displacement allocation

Sugarcane bagasse does have the lowest GHG emissions and uses the least amount of fossil fuels, but is currently not grown very much in the United States. If large amount of sugarcane bagasse were needed to make biofuels, significant imports of cane from Brazil may be needed. Switchgrass is native to much of the United States and has a yield of 13.6 MT/ha in many locations. Switchgrass also usually sequesters carbon in the soil, which results in a high dLUC credit compared to many prior land uses. Switchgrass also grows on marginal lands and may not compete with food crops or create iLUC impacts. When looking at sustainability and feedstock availability in the United States switchgrass has the potential to be a very significant feedstock.

\subsubsection{Pyrolysis and Stabilization}

Stabilized pyrolysis oil derived from low ash corn stover releases only $-4.04 \mathrm{~g}$ of $\mathrm{CO}_{2} / \mathrm{MJ}$ of biofuel and fossil energy credits more than offset fossil energy consumption with a net $-0.0503 \mathrm{MJ}$ of fossil energy/MJ of stabilized pyrolysis oil. This low GHG emission and 
negative fossil energy use is because of the displacement credit from the co-products. Stabilized pyrolysis oil is potentially an attractive fuel for electricity production to replace coal or other types of nonrenewable fuels currently used to produce electricity. Stabilized pyrolysis oil from sugarcane bagasse and waste wood also had low GHG emissions, while stabilized pyrolysis oil from algae had the highest GHG emissions and FED because of high inputs for algae production.

\subsubsection{Upgrading to Hydrocarbon Biofuels}

The upgrading input that had the largest effect on the overall GHG emissions was the natural gas used to produce hydrogen. Natural gas used to produce hydrogen usually was also the main contributor of fossil energy. The total GHG emissions ranged from 10.7 to $74.3 \mathrm{~g} \mathrm{CO}_{2}$ eq./MJ for sugarcane bagasse and wild algae respectively as shown in Figure 6.4. The remaining biofuel results depend on the amount of natural gas during upgrading and fertilizer inputs and fuel inputs during feedstock production.

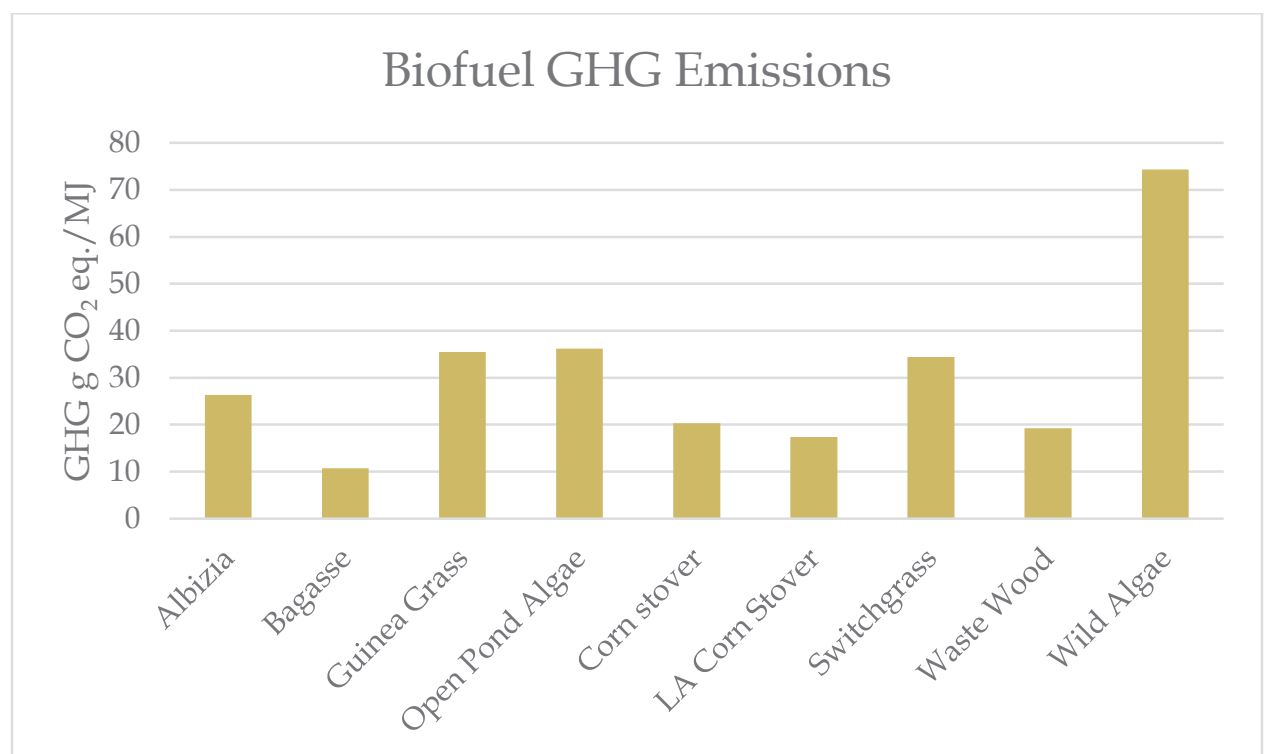

Figure 6.4 GHG emissions of each biofuel with a functional unit of $1 \mathrm{MJ}$ of biofuel for displacement allocation

The biofuel that had the lowest GHG emissions was derived from sugarcane bagasse, 
which had a GHG emission percent savings compared to conventional nonrenewable gasoline of $88 \%$. Wild algae released the most emissions but still saved 19\% compared to nonrenewable gasoline. With the exception of wild algae derived biofuel the rest of the biofuels had a GHG emission savings of more than 50\% compared to gasoline. Therefore, based on this study pyrolysis-based biofuels produced from a variety of biomass feedstocks will meet the GHG savings target for advanced biofuels of 50\% and in some the $60 \%$ threshold for cellulosic fuels as mandated by the Renewable Fuels Standard.

Similar to the GHG emission sugarcane bagasse had the lowest total CED and FED as shown in Figure 6.5 and 6.6. Sugarcane bagasse uses $0.118 \mathrm{MJ}$ of fossil fuels for every $\mathrm{MJ}$ of biofuel and $1.25 \mathrm{MJ}$ of total energy for every MJ of biofuel. The difference between the FED and CED is mostly energy from renewable biomass (1.05 MJ/MJ) as shown in Figure 6.3. The biofuels that are derived from a waste like waste wood and bagasse have the lowest FED and CED. As more fertilizers and fuel is used in feedstock production the higher the FED and CED as the biofuels derived from guinea grass and switchgrass shows in Figure 6.5. The algae derived biofuel used the most electricity in feedstock production and resulted in the largest FED and CED. 


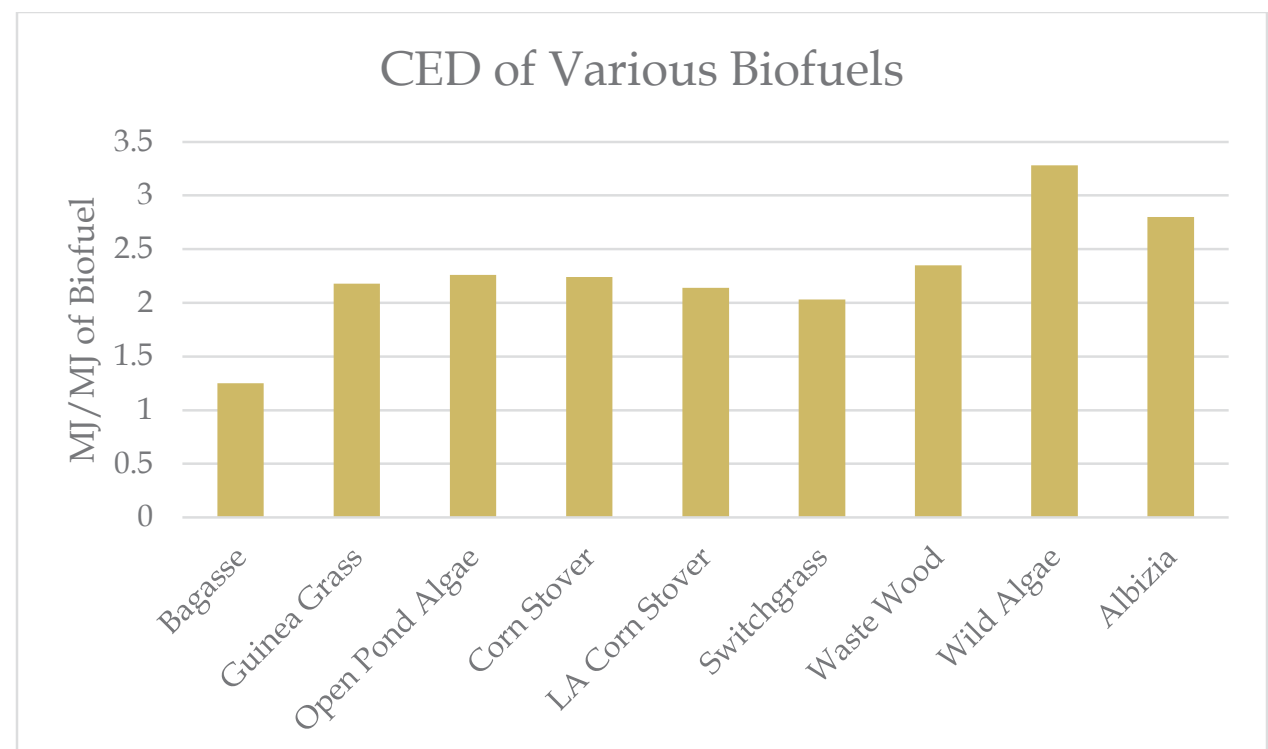

Figure 6.5 Total FED for each biofuel with a function unit of one MJ for displacement allocation

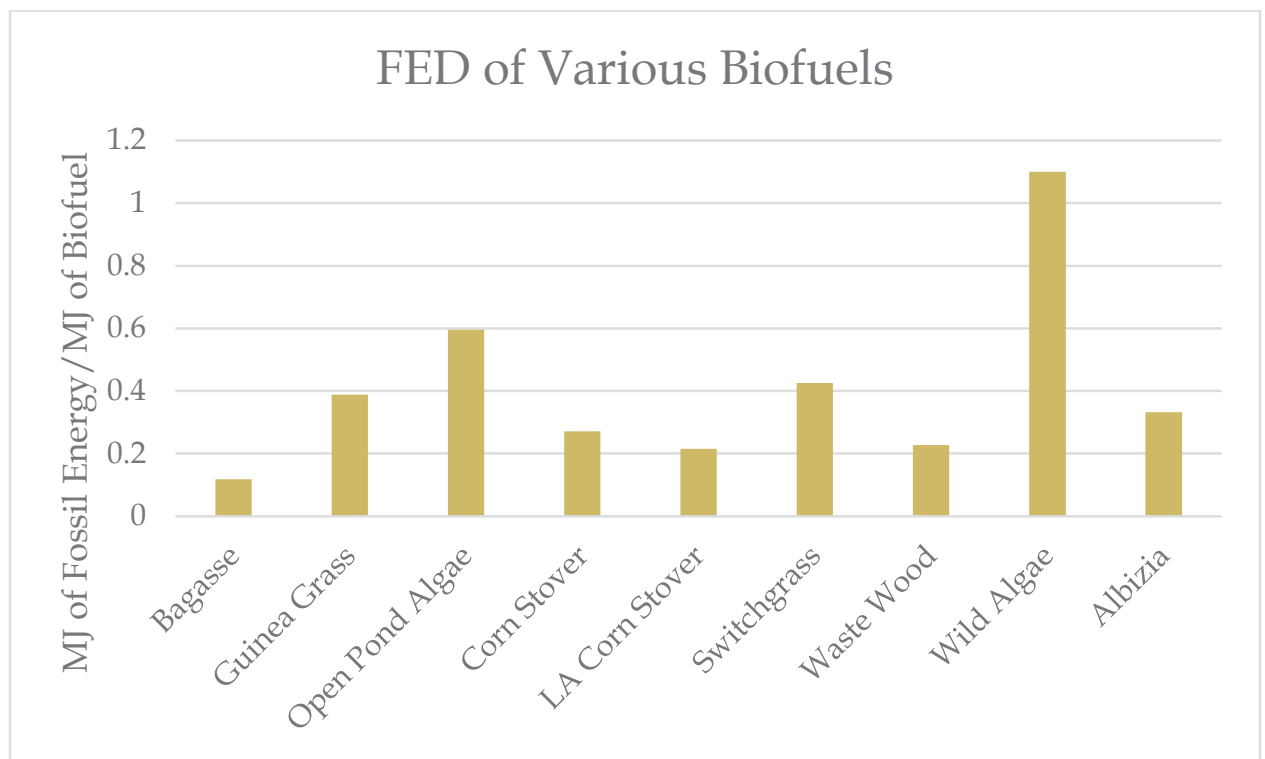

Figure 6.6 Total FED for each biofuel with a function unit of one MJ for displacement allocation

\subsection{Recommendations}

The LCA results in this MS thesis leads to the recommendation that biofuels derived from waste products like sugarcane bagasse and waste wood should be used whenever 
possible as the feedstock to produce biofuels. When there is limited supply of waste products energy crops such as grasses and woody biomass may also be considered because, with the exception of wild algae, energy crop based biofuels also can reduce the GHG emissions by more than 50\% compared to nonrenewable gasoline. 


\section{References}

CARB. 2009a. Detailed California-Modified GREET Pathway for Brazilian Sugar Cane Ethanol.

CARB. 2009b. Detailed California-Modified GREET Pathway for Corn Ethanol.

Cherubini F, Jungmeier G. 2010. LCA of a biorefinery concept producing bioethanol, bioenergy, and chemicals from switchgrass. The Internation Journal of Life Cycle Assessment 15(1):53-66.

Diebold JP, Czernik S. 1997. Additives To Lower and Stabilize the Viscosity of Pyrolysis Oils during Storage. Energy \& Fuels 11(5):1081-1091.

Eisentraut A. 2010. Sustainable Production of Second-Generation Biofuels Potential and perspectives in major economies and developing countries. International Energy Agency.

Ellis S. Rural America: An Update On Unemployment And Poverty. October 07, 2011]. Available from: http://www.farmgateblog.com/article/rural-america-an-updateon-unemployment-and-poverty

EPA. 2010a. Regulation of Fuels and Fuel Additives: Changes to Renewable Fuel Standard Program Vol. 75 No. 58.

EPA. 2010b. Domestic Agricultural Projections from the Forest and Agricultural Sector Optimization Model (FASOM) Document ID: $\quad$ EPA-HQ-OAR-2005-01613150.1 .

eGRIDweb [Internet]. 2005. [updated cited. Available from: http://cfpub.epa.gov/egridweb/view st.cfm

Fan J, Kalnes TN, Alward M, Klinger J, Sadehvandi A, Shonnard DR. 2011. Life cycle assessment of electricity generation using fast pyrolysis bio-oil. Renewable Energy 36(2):632-641.

Global Insight. 2008. U.S. Metro Economies Current and Potential Green Jobs in the U.S. Economy. Global Insight, Inc.

Hsu DD. 2011. Life Cycle Assessment of Gasoline and Diesel Produced via Fast Pyrolysis and Hydroprocessing. NREL.

Inc. STC. 2011. The Addition of Pyrolysis Oil Pathways to GHGenius.

Jones S, Valkenburg C, Walton C, Elliott D, Holladay J, Stevens D, Kinchin C, Czernik S. 2009. Production of Gasoline and Diesel from Biomass via Fast Pyrolysis, Hydrotreating and Hydrocracking: A Design Case. In: Energy USDo, editor.

Kauffman N, Hayes D, Brown R. 2011. A life cycle assessment of advanced biofuel production from a hectare of corn. Fuel 90(11):3306-3314.

Kim S, Dale B, Jenkins R. 2009. Life cycle assessment of corn grain and corn stover in the United States. The International Journal of Life Cycle Assessment 14(2):160174.

Morey RV, Kaliyan N, Tiffany DG, Schmidt DR. 2010. A Corn Stover Supply Logistics System. Applied Engineering in Agriculture 26(3):455-461.

NETL. 2008. Development of baseline Data and Analysis of Life Cycle Greenhouse Gas Emissions of Petroleum-Based Fuels. 
Sokhansanj S, Mani S, Tagore S, Turhollow AF. 2010. Techno-economic analysis of using corn stover to supply heat and power to a corn ethanol plant. Biomass and Bioenergy 34:75-81.

Spatari S, Zhang Y, Maclean HL. 2005. Life Cycle Assessment of Switchgrass- and Corn Stover-Derived Ethanol-Fueled Automobilies. Environ. Sci. Technol. 39:97509758.

Stratton RW, Wong HM, Hileman JI. 2010. Life Cycle Greenhouse Gas Emissions from Alternative Jet Fuels: Partner Project 28 report Version 1.2.

Tenbruggencate J. Green Acres From green power timber to revenue-producing green waste, Bill Cowern is harnessing global forces for local gain. September 2008]. Available from: http://www.hawaiibusiness.com/Hawaii-Business/September2008/Green-Acres/

U.S. Department of Energy. 2011. U.S. Billion-Ton Update Biomass Supply for a Bioenergy and Bioproducts industry. R.D. Perlack and B.J. Stokes (Leads), ORNL/TM-2011/224. Oak Ridge National Laboratory, Oak Ridge, TN. 227p. 


\section{Appendix 1}

No Tables or figures associated with chapter 1 in appendix and therefore left blank. 


\section{Appendix 2}

Table A2.1: EAF of each feedstock for pyrolysis, stabilization, and upgrading.

\begin{tabular}{lccc}
\hline & Pyrolysis & Stabilization & Upgrading \\
\hline Albizia & 0.87 & 0.95 & 0.80 \\
Corn Stover & 0.88 & 0.93 & 0.83 \\
Corn Stover Low Ash & 0.77 & 0.94 & 0.82 \\
Switchgrass & 0.89 & 0.95 & 0.81 \\
Guinea Grass & 0.97 & 0.96 & 0.82 \\
Sugarcane Bagasse & 0.93 & 0.96 & 0.85 \\
Waste Wood & 0.83 & 0.95 & 0.83 \\
Wild Algae & 0.97 & 0.92 & 0.84 \\
Open Pond Algae & 0.91 & 0.95 & 0.85 \\
\hline
\end{tabular}

Albizia

$\frac{1 \mathrm{~kg} \text { of pyrolysis oil } * 16.6 \mathrm{LHV} \text { of pyrolysis oil }}{1 \mathrm{~kg} \text { of pyrolysis oil } * 16.6 \mathrm{LHV} \text { of pyrolysis oil }+0.78 \mathrm{~kg} \text { of steam } * 3.2 \text { primary energy of steam }}=0.87$
$\frac{0.958 \mathrm{~kg} \text { of filtered pyoil } * 16.188 \mathrm{LHV} \text { of filtered pyoil }}{0.958 \mathrm{~kg} \text { of filtered pyoil } * 16.188 \mathrm{LHV} \text { of filtered pyoil }+0.042 \mathrm{~kg} \text { of filter cake } * 21.3 \mathrm{LHV} \text { of filter cake }}$
$=0.95$
$\frac{1 \mathrm{~kg} \text { of biof } \mathrm{kel} * 43 \mathrm{LHV} \text { of biofuel }}{01 \mathrm{~kg} \text { of biofuel } * 43 \mathrm{LHV} \text { of biofuel }+3.34 \mathrm{~kg} \text { of steam } * 3.2 \text { primary energy of steam }}=0.80$

\section{Corn Stover}

$1 \mathrm{~kg}$ of pyrolysis oil $* 16.4 \mathrm{LHV}$ of pyrolysis oil

$1 \mathrm{~kg}$ of pyrolysis oil $* 16.4 \mathrm{LHV}$ of pyrolysis oil $+0.68 \mathrm{~kg}$ of steam $* 3.2$ primary energy of steam

$=0.88$

$0.93 \mathrm{~kg}$ of filtered pyoil $* 16.492 \mathrm{LHV}$ of filtered pyoil $0.93 \mathrm{~kg}$ of filtered pyoil $* 16.492 \mathrm{LHV}$ of filtered pyoil $+0.07 \mathrm{~kg}$ of filter cake $* 16.6 \mathrm{LHV}$ of filter cake $=$ 0.93

$1 \mathrm{~kg}$ of biofuel $* 43 \mathrm{LHV}$ of biofuel $01 \mathrm{~kg}$ of biofuel $* 43 \mathrm{LHV}$ of biofuel $+2.8 \mathrm{~kg}$ of steam $* 3.2$ primary energy of steam $=0.83$

Low Ash Corn Stover 
$1 \mathrm{~kg}$ of pyrolysis oil $* 14.4 \mathrm{LHV}$ of pyrolysis oil

$1 \mathrm{~kg}$ of pyrolysis oil $* 14.4 \mathrm{LHV}$ of pyrolysis oil $+1.33 \mathrm{~kg}$ of steam $* 3.2$ primary energy of steam

$=0.77$

$0.956 \mathrm{~kg}$ of filtered pyoil $* 15.638 \mathrm{LHV}$ of filtered pyoil

$0.956 \mathrm{~kg}$ of filtered pyoil $* 15.638 \mathrm{LHV}$ of filtered pyoil $+0.044 \mathrm{~kg}$ of filter cake $* 21.6 \mathrm{LHV}$ of filter cake

$=0.94$

$1 \mathrm{~kg}$ of biofuel $* 43 \mathrm{LHV}$ of biofuel

$01 \mathrm{~kg}$ of biofuel $* 43 \mathrm{LHV}$ of biofuel $+3.0 \mathrm{~kg}$ of steam $* 3.2$ primary energy of steam $=0.82$

\section{Switchgrass}

$1 \mathrm{~kg}$ of pyrolysis oil $* 16.6 \mathrm{LHV}$ of pyrolysis oil

$1 \mathrm{~kg}$ of pyrolysis oil $* 16.6 \mathrm{LHV}$ of pyrolysis oil $+0.61 \mathrm{~kg}$ of steam $* 3.2$ primary energy of steam

$0.961 \mathrm{~kg}$ of filtered pyoil $* 16.188 \mathrm{LHV}$ of filtered pyoil

$0.961 \mathrm{~kg}$ of filtered pyoil $* 16.188 \mathrm{LHV}$ of filtered pyoil $+0.039 \mathrm{~kg}$ of filter cake $* 21.3 \mathrm{LHV}$ of filter cake

$=0.95$

$1 \mathrm{~kg}$ of biofuel $* 43 \mathrm{LHV}$ of biofuel

$01 \mathrm{~kg}$ of biofuel $* 43 \mathrm{LHV}$ of biofuel $+3.0 \mathrm{~kg}$ of steam $* 3 . .08$ primary energy of steam $=0.81$

\section{Guinea Grass}

$1 \mathrm{~kg}$ of pyrolysis oil $* 17$ LHV of pyrolysis oil $=0.97$

$1 \mathrm{~kg}$ of pyrolysis oil $* 17 \mathrm{LHV}$ of pyrolysis oil $+0.15 \mathrm{~kg}$ of steam $* 3.2$ primary energy of steam

$0.949 \mathrm{~kg}$ of filtered pyoil $* 17.624 \mathrm{LHV}$ of filtered pyoil

$0.949 \mathrm{~kg}$ of filtered pyoil $* 17.624 \mathrm{LHV}$ of filtered pyoil $+0.051 \mathrm{~kg}$ of filter cake $* 15.2 \mathrm{LHV}$ of filter cake

$=0.96$

$1 \mathrm{~kg}$ of biofuel $* 43 \mathrm{LHV}$ of biofuel $=0.82$

$01 \mathrm{~kg}$ of biofuel $* 43 \mathrm{LHV}$ of biofuel $+2.92 \mathrm{~kg}$ of steam $* 3.2$ primary energy of steam

Sugarcane Bagasse

$1 \mathrm{~kg}$ of pyrolysis oil $* 20.6 \mathrm{LHV}$ of pyrolysis oil $1 \mathrm{~kg}$ of pyrolysis oil $* 20.6 \mathrm{LHV}$ of pyrolysis oil $+0.49 \mathrm{~kg}$ of steam $* 3.2$ primary energy of steam $=0.93$

$0.968 \mathrm{~kg}$ of filtered pyoil $* 20.934 \mathrm{LHV}$ of filtered pyoil $0.968 \mathrm{~kg}$ of filtered pyoil $* 20.934 \mathrm{LHV}$ of filtered pyoil $+0.032 \mathrm{~kg}$ of filter cake $* 23 \mathrm{LHV}$ of filter cake $=$ 0.96 
$1 \mathrm{~kg}$ of biofuel $* 43 \mathrm{LHV}$ of biofuel

$01 \mathrm{~kg}$ of biofuel $* 43 \mathrm{LHV}$ of biofuel $+2.38 \mathrm{~kg}$ of steam $* 3.2$ primary energy of steam $=0.85$

\section{Waste Wood}

$1 \mathrm{~kg}$ of pyrolysis oil $* 16.6 \mathrm{LHV}$ of pyrolysis oil

0.83

$1 \mathrm{~kg}$ of pyrolysis oil $* 16.6 \mathrm{LHV}$ of pyrolysis oil $+1.05 \mathrm{~kg}$ of steam $* 3.2$ primary energy of steam

$0.961 \mathrm{~kg}$ of filtered pyoil $* 15.638 \mathrm{LHV}$ of filtered pyoil

$0.956 \mathrm{~kg}$ of filtered pyoil $* 15.638 \mathrm{LHV}$ of filtered pyoil $+0.044 \mathrm{~kg}$ of filter cake $* 21.6 \mathrm{LHV}$ of filter cake

$=0.95$

$1 \mathrm{~kg}$ of biofuel $* 43 \mathrm{LHV}$ of biofuel

$01 \mathrm{~kg}$ of biofuel $* 43 \mathrm{LHV}$ of biofuel $+2.83 \mathrm{~kg}$ of steam $* 3.2$ primary energy of steam $=0.83$

Wild Algae

$1 \mathrm{~kg}$ of pyrolysis oil $* 23.6 \mathrm{LHV}$ of pyrolysis oil

$1 \mathrm{~kg}$ of pyrolysis oil $* 23.6 \mathrm{LHV}$ of pyrolysis oil $+0.24 \mathrm{~kg}$ of steam $* 3.2$ primary energy of steam $=0.97$

$0.898 \mathrm{~kg}$ of filtered pyoil $* 24.146 \mathrm{LHV}$ of filtered pyoil

$0.898 \mathrm{~kg}$ of filtered pyoil $* 24.146 \mathrm{LHV}$ of filtered pyoil $+0.102 \mathrm{~kg}$ of filter cake $* 18.3 \mathrm{LHV}$ of filter cake

$=0.92$

$1 \mathrm{~kg}$ of biofuel $* 43 \mathrm{LHV}$ of biofuel

$01 \mathrm{~kg}$ of biofuel $* 43 \mathrm{LHV}$ of biofuel $+2.65 \mathrm{~kg}$ of steam $* 3.2$ primary energy of steam $=0.84$

\section{Open Pond Algae}

$1 \mathrm{~kg}$ of pyrolysis oil $* 24.5 \mathrm{LHV}$ of pyrolysis oil

$1 \mathrm{~kg}$ of pyrolysis oil $* 24.5 \mathrm{LHV}$ of pyrolysis oil $+0.73 \mathrm{~kg}$ of steam $* 3.2$ primary energy of steam $=0.91$

$0.952 \mathrm{~kg}$ of filtered pyoil $* 24.561 \mathrm{LHV}$ of filtered pyoil

$0.952 \mathrm{~kg}$ of filtered pyoil $* 24.561 \mathrm{LHV}$ of filtered pyoil $+0.048 \mathrm{~kg}$ of filter cake $* 23.7 \mathrm{LHV}$ of filter cake

$=0.95$

$1 \mathrm{~kg}$ of biofuel $* 43 \mathrm{LHV}$ of biofuel

$\frac{1 \mathrm{~kg} \text { of biofuel } * 43 \mathrm{LHV} \text { of biofuel }}{01 \mathrm{~kg} \text { of biofuel } * 43 \mathrm{LHV} \text { of biofuel }+2.32 \mathrm{~kg} \text { of steam } * 3.2 \text { primary energy of steam }}=0.85$ 
Appendix 3

Table A3.1: Albizia inputs mostly from the UP Survey and some from Grays Harbor (see Table A3.6) with a basis of one dry metric ton.

\begin{tabular}{lcc}
\hline \multicolumn{1}{c}{ Albizia } & $\begin{array}{c}\text { UP Survey / } \\
\text { Grays Harbor }\end{array}$ & Units \\
\hline Chainsaw Harvest & & \\
Lubricating Oil & 0.0748 & $\mathrm{~kg}$ \\
Gasoline & 0.436 & $\mathrm{~kg}$ \\
Diesel & 0.828 & $\mathrm{~kg}$ \\
Combustion-Diesel & 0.828 & $\mathrm{~kg}$ \\
Combustion-Gasoline & 0.436 & $\mathrm{~kg}$ \\
Collecting/Loading & & \\
Diesel & 3.34 & $\mathrm{~kg}$ \\
Combustion-Diesel & 3.34 & $\mathrm{~kg}$ \\
Machinery & $9.26 \mathrm{E}-6$ & $\mathrm{p}$ \\
Transportation & & \\
Transport truck & 80.6 & $\mathrm{tkm}$ \\
Transport Barge & 403 & $\mathrm{tkm}$ \\
Unloading/Storage & & \\
Diesel & 1.86 & $\mathrm{~kg}$ \\
Combustion-Diesel & 1.86 & $\mathrm{~kg}$ \\
Machinery & $9.26 \mathrm{E}-9$ & $\mathrm{p}$ \\
Chipping and Grinding & & \\
Diesel & 1.05 & $\mathrm{~kg}$ \\
Combustion-Diesel & 1.05 & $\mathrm{~kg}$ \\
Electricity-Hawaiian & 23.4 & $\mathrm{kWh}$ \\
Chipper and Grinder & $5.51 \mathrm{E}-6$ & $\mathrm{p}$ \\
Collecting/Loading & & \\
Diesel & 3.34 & $\mathrm{~kg}$ \\
Combustion-Diesel & 3.34 & $\mathrm{~kg}$ \\
Machinery & $9.26 \mathrm{E}-6$ & $\mathrm{p}$ \\
\hline
\end{tabular}


Table A3.2: Switchgrass inputs for three scenarios (SimaPro, Ceres, and Literature) at different transportation distances $(15,25$, and 50 miles) from Ceres and inputs from literature with a basis of one dry metric ton

\begin{tabular}{|c|c|c|c|c|}
\hline Switchgrass Inputs & SimaPro & Ceres & Literature* & Units \\
\hline \multicolumn{5}{|l|}{ Land Prep. / Planting } \\
\hline Diesel & & 0.97 & --- & $\mathrm{kg} / \mathrm{ha}$ \\
\hline Grease & & $2.72 \mathrm{E}-03$ & --- & $\mathrm{kg} / \mathrm{ha}$ \\
\hline Hydraulic oil & & $3.40 \mathrm{E}-03$ & --- & $\mathrm{kg} / \mathrm{ha}$ \\
\hline Lubricating oil & & $5.79 \mathrm{E}-03$ & --- & $\mathrm{kg} / \mathrm{ha}$ \\
\hline Combustion-Diesel & & 0.97 & --- & $\mathrm{kg} / \mathrm{ha}$ \\
\hline $\begin{array}{l}\text { Combustion- } \\
\text { Lubricating Oil }\end{array}$ & & $5.79 \mathrm{E}-03$ & --- & $\mathrm{kg} / \mathrm{ha}$ \\
\hline \multicolumn{5}{|l|}{ Cultivating } \\
\hline $\begin{array}{l}\text { Diesel } \\
\text { Nitrogen (Table A3.3) }\end{array}$ & & 12.1 & --- & $\mathrm{kg} / \mathrm{ha}$ \\
\hline $\begin{array}{l}\text { Potassium sulfate, as } \\
\mathrm{K}_{2} \mathrm{O}\end{array}$ & & 106 & 54 & $\mathrm{~kg} / \mathrm{ha}$ \\
\hline $\begin{array}{l}\text { Monoammonium } \\
\text { phosphate, as } \mathrm{P}_{2} \mathrm{O}_{5}\end{array}$ & & 101 & 17 & $\mathrm{~kg} / \mathrm{ha}$ \\
\hline Limestone & & 640 & 150 & $\mathrm{~kg} / \mathrm{ha}$ \\
\hline $\begin{array}{l}\mathrm{CO}_{2} \text { from limestone } \\
\text { application }\end{array}$ & & 640 & 150 & $\mathrm{~kg} / \mathrm{ha}$ \\
\hline Hydraulic oil & & 4.28E-02 & --- & $\mathrm{kg} / \mathrm{ha}$ \\
\hline Grease & & $3.42 \mathrm{E}-02$ & --- & $\mathrm{kg} / \mathrm{ha}$ \\
\hline Lubricating oil & & $7.28 \mathrm{E}-02$ & --- & $\mathrm{kg} / \mathrm{ha}$ \\
\hline Combustion-Diesel & & 12.1 & --- & $\mathrm{kg} / \mathrm{ha}$ \\
\hline Tractor production & 0.687 & --- & --- & $\mathrm{kg} / \mathrm{ha}$ \\
\hline $\begin{array}{l}\text { Agricultural } \\
\text { machinery production }\end{array}$ & 0.241 & --- & --- & $\mathrm{kg} / \mathrm{ha}$ \\
\hline $\begin{array}{l}\text { Combustion- } \\
\text { Lubricating Oil } \\
\text { Harvest }\end{array}$ & & $7.28 \mathrm{E}-02$ & & $\mathrm{~kg} / \mathrm{ha}$ \\
\hline Diesel & & 139 & --- & $\mathrm{kg} / \mathrm{ha}$ \\
\hline Lubricating oil & & 0.83 & --- & $\mathrm{kg} / \mathrm{ha}$ \\
\hline Hydraulic oil & & 0.49 & --- & $\mathrm{kg} / \mathrm{ha}$ \\
\hline Grease & & 0.39 & --- & $\mathrm{kg} / \mathrm{ha}$ \\
\hline Combustion-Diesel & & 139 & --- & $\mathrm{kg} / \mathrm{ha}$ \\
\hline $\begin{array}{l}\text { Agricultural } \\
\text { machinery production }\end{array}$ & 26.6 & --- & --- & $\mathrm{kg} / \mathrm{ha}$ \\
\hline Tractor production & 6.14 & --- & --- & $\mathrm{kg} / \mathrm{ha}$ \\
\hline $\begin{array}{l}\text { Combustion- } \\
\text { Lubricating Oil }\end{array}$ & & 0.83 & --- & $\mathrm{kg} / \mathrm{ha}$ \\
\hline $\begin{array}{l}\text { Transportation } 15 \\
\text { miles scenario Ceres }\end{array}$ & & & & \\
\hline
\end{tabular}




\begin{tabular}{lccc}
\hline $\begin{array}{l}\text { Truck } \\
\text { Transportation 25 } \\
\text { miles scenario Ceres } \\
\text { Truck }\end{array}$ & 24.19 & --- & tkm \\
\hline $\begin{array}{l}\text { Transportation 50 } \\
\text { miles scenario Ceres }\end{array}$ & 40.32 & --- & tkm \\
$\begin{array}{l}\text { Truck } \\
\begin{array}{l}\text { Switchgrass } \\
\text { Transportation }\end{array}\end{array}$ & & & \\
Truck & 80.65 & --- & tkm \\
\hline
\end{tabular}

*(Cherubini and Jungmeier 2010)

Table A3.3: Nitrogen fertilizer related inputs for switchgrass at several different location scenarios with units of $\mathrm{kg}$ per one dry metric ton.

\begin{tabular}{lccccc}
\hline Nitrogen Fertilizer & $\# 1$ & $\# 2$ & $\# 3$ & $\# 4$ & $\# 5$ \\
\hline Urea, as N & & & & &
\end{tabular}

Ammonium nitrate, as $\mathbf{N}$

$\mathrm{N}_{2} \mathrm{O}$ emission from $\mathrm{N}$ fertilizer

Git og from urea anplication

Urea, as $\mathbf{N}$

Ammonium nitrate, as $\mathbf{N}$

$\mathrm{N}_{2} \mathrm{O}$ emission from $\mathrm{N}$ fertilizer

$\mathrm{CO}_{2}$ from urea application

Table A3.4: Average annual $\mathrm{CO} 2$ Sequestration for switchgrass at several locations (from Ceres)

\begin{tabular}{lc}
\hline Locations & kg CO$_{2} /$ dry MT \\
\hline Munich, ND & 96 \\
Streeter, ND & 48 \\
Bristol, SD & 248 \\
Highmore, SD & 77 \\
Huron, SD & -31 \\
Ethan, SD & -37 \\
Crofton, NE & 41 \\
Atkinson, NE & 66 \\
Douglas, NE & 120 \\
Lawrence, NE & 123 \\
Average & 75 \\
\hline
\end{tabular}


Table A3.5: Inventory data for algae cultivation, harvesting, and transport for Aquaflow Bionomic Corporation with a basis of one dry metric ton and an algae density of 300 g/m3. (C.D. = Confidential Data)

\begin{tabular}{lll}
\hline \multicolumn{1}{c}{ Wild Algae } & Inputs & Units \\
\hline $\begin{array}{l}\text { Cultivation } \\
\text { chemical additives }\end{array}$ & C.D. & metric tons \\
$\begin{array}{lll}\text { Pump shed } \\
\text { motor (0) }\end{array}$ & C.D. & $\mathrm{kWh}$ \\
motor (1) & C.D. & $\mathrm{kWh}$ \\
motor (Inc.) & C.D. & $\mathrm{kWh}$ \\
motor (3) & C.D. & $\mathrm{kWh}$ \\
motor (5) & C.D. & $\mathrm{kWh}$ \\
New Harvest Units & & \\
motor (6) & C.D. & $\mathrm{kWh}$ \\
motor (7) & C.D. & $\mathrm{kWh}$ \\
motor (8) & C.D. & $\mathrm{kWh}$ \\
motor (9) & C.D. & $\mathrm{kWh}$ \\
motor (10) & C.D. & $\mathrm{kWh}$ \\
motor (11) & C.D. & $\mathrm{kWh}$ \\
De-watering & & \\
motor (12) & C.D. & $\mathrm{kWh}$ \\
motor (13) & C.D. & $\mathrm{kWh}$ \\
Transportation & C.D. & $\mathrm{km}$ \\
\hline
\end{tabular}


Table A3.6: Waste wood inputs with a basis of one dry metric ton (C.D. = Confidential Data)

\begin{tabular}{|c|c|c|c|}
\hline Waste Wood & Grays Harbor & UP Survey & Units \\
\hline \multicolumn{4}{|l|}{ Collecting/Loading } \\
\hline \multicolumn{4}{|l|}{ Materials/Assemblies } \\
\hline Diesel & & 3.34 & $\mathrm{~kg}$ \\
\hline \multicolumn{4}{|l|}{ Processes } \\
\hline Combustion-Diesel & & 3.34 & $\mathrm{~kg}$ \\
\hline Machinery & & $9.26 \mathrm{E}-06$ & $\mathrm{p}$ \\
\hline \multicolumn{4}{|l|}{ Transportation } \\
\hline \multicolumn{4}{|l|}{ Processes } \\
\hline Transport truck & C.D. & & tkm \\
\hline \multicolumn{4}{|l|}{ Unloading/Storage } \\
\hline \multicolumn{4}{|l|}{ Materials/Assemblies } \\
\hline Diesel & & 1.86 & $\mathrm{~kg}$ \\
\hline \multicolumn{4}{|l|}{ Processes } \\
\hline Combustion-Diesel & & 1.86 & $\mathrm{~kg}$ \\
\hline Machinery & & $9.26 \mathrm{E}-06$ & $\mathrm{p}$ \\
\hline \multicolumn{4}{|l|}{ Chipping and Grinding } \\
\hline \multicolumn{4}{|l|}{ Materials/Assemblies } \\
\hline Diesel & & 0.11 & $\mathrm{~kg}$ \\
\hline \multicolumn{4}{|l|}{ Processes } \\
\hline Combustion-Diesel & & 0.11 & $\mathrm{~kg}$ \\
\hline $\begin{array}{l}\text { Electricity WA State } \\
\text { Emissions }\end{array}$ & C.D. & & $\mathrm{kWh}$ \\
\hline Chipper and Grinder & & $5.51 \mathrm{E}-06$ & $\mathrm{p}$ \\
\hline
\end{tabular}


Table A3.7: Guinea grass inputs for two scenarios with different land preparation requirements and a scenario on unmanaged land with a basis of one dry metric ton (C.D. $=$ Confidential Data)

\begin{tabular}{|c|c|c|c|}
\hline Guinea Grass Inputs & SimaPro & Inputs & Units \\
\hline \multicolumn{4}{|l|}{ Land Prep minimal vegetation } \\
\hline \multicolumn{4}{|l|}{ Materials/Assemblies } \\
\hline Diesel & & C.D. & $\mathrm{kg}$ \\
\hline \multicolumn{4}{|l|}{ Processes } \\
\hline Combustion-Diesel & & C.D. & $\mathrm{kg}$ \\
\hline \multicolumn{4}{|l|}{ Land Prep medium vegetation } \\
\hline \multicolumn{4}{|l|}{ Materials/Assemblies } \\
\hline Diesel & & C.D. & $\mathrm{kg}$ \\
\hline \multicolumn{4}{|l|}{ Processes } \\
\hline Combustion-Diesel & & C.D. & $\mathrm{kg}$ \\
\hline \multicolumn{4}{|l|}{ Cultivation } \\
\hline \multicolumn{4}{|l|}{ Materials/Assemblies } \\
\hline Diesel & & C.D. & $\mathrm{kg}$ \\
\hline Urea, as $\mathbf{N}$ & & C.D. & $\mathrm{kg}$ \\
\hline $\mathrm{N}_{2} \mathrm{O}$ emission from $\mathrm{N}$ fertilizer & & C.D. & $\mathrm{kg}$ \\
\hline $\mathrm{CO}_{2}$ from urea application & & C.D. & $\mathrm{kg}$ \\
\hline Potassium sulfate, as $\mathrm{K}_{2} \mathrm{O}$ & & C.D. & $\mathrm{kg}$ \\
\hline Thomas meal, as $\mathrm{P}_{2} \mathrm{O}_{5}$ & & C.D. & $\mathrm{kg}$ \\
\hline Lubricating oil & & C.D. & $\mathrm{kg}$ \\
\hline Hydraulic oil & & C.D. & $\mathrm{kg}$ \\
\hline Grease & & C.D. & $\mathrm{kg}$ \\
\hline \multicolumn{4}{|l|}{ Processes } \\
\hline Combustion-Diesel & & C.D. & $\mathrm{kg}$ \\
\hline Tractor, production & 0.687 & --- & $\mathrm{kg} / \mathrm{ha}$ \\
\hline $\begin{array}{l}\text { Agricultural machinery } \\
\text { production }\end{array}$ & 0.241 & --- & $\mathrm{kg} / \mathrm{ha}$ \\
\hline Combustion-Lubricating Oil & & C.D. & $\mathrm{kg}$ \\
\hline \multicolumn{4}{|l|}{ Harvest (Unmanaged Land) } \\
\hline \multicolumn{4}{|l|}{ Materials/Assemblies } \\
\hline Diesel & & C.D. & $\mathrm{kg}$ \\
\hline Grease & & C.D. & $\mathrm{kg}$ \\
\hline Hydraulic oil & & C.D. & $\mathrm{kg}$ \\
\hline Lubricating oil & & C.D. & $\mathrm{kg}$ \\
\hline \multicolumn{4}{|l|}{ Processes } \\
\hline Combustion-Diesel & & C.D. & $\mathrm{kg}$ \\
\hline Tractor, production & 26.6 & --- & $\mathrm{kg} / \mathrm{ha}$ \\
\hline
\end{tabular}




\begin{tabular}{|c|c|c|c|}
\hline $\begin{array}{l}\text { Agricultural machinery } \\
\text { production } \\
\text { Combustion-Lubricating Oil }\end{array}$ & 6.14 & $\begin{array}{l}--- \\
\text { C.D. }\end{array}$ & $\begin{array}{c}\mathrm{kg} / \mathrm{ha} \\
\mathrm{kg}\end{array}$ \\
\hline \multicolumn{4}{|l|}{ Harvest (Managed Land) } \\
\hline \multicolumn{4}{|l|}{ Materials/Assemblies } \\
\hline Diesel & & C.D. & $\mathrm{kg}$ \\
\hline Grease & & C.D. & $\mathrm{kg}$ \\
\hline Hydraulic oil & & C.D. & $\mathrm{kg}$ \\
\hline Lubricating oil & & C.D. & $\mathrm{kg}$ \\
\hline \multicolumn{4}{|l|}{ Processes } \\
\hline Combustion-Diesel & & C.D. & $\mathrm{kg}$ \\
\hline Tractor, production & 26.6 & --- & $\mathrm{kg} / \mathrm{ha}$ \\
\hline $\begin{array}{l}\text { Agricultural machinery } \\
\text { production }\end{array}$ & 6.14 & --- & $\mathrm{kg} / \mathrm{ha}$ \\
\hline Combustion-Lubricating Oil & & C.D. & $\mathrm{kg}$ \\
\hline \multicolumn{4}{|l|}{ Transport } \\
\hline \multicolumn{4}{|l|}{ Materials/Assemblies } \\
\hline Diesel (Trucking) & & C.D. & $\mathrm{kg}$ \\
\hline Diesel (Oceanic barge) & & C.D. & $\mathrm{kg}$ \\
\hline \multicolumn{4}{|l|}{ Processes } \\
\hline Truck & & C.D. & $\mathrm{tkm}$ \\
\hline Oceanic barge & & C.D. & $\mathrm{tkm}$ \\
\hline
\end{tabular}

Table A.3.8 Hawaiian Electricity Mix(U.S. EPA 2005)

\begin{tabular}{lc}
\hline \multicolumn{1}{c}{ Emissions } & Ib of emissions per $\mathbf{M W h}$ \\
\hline $\mathrm{CO}_{2}$ & 1731.01 \\
$\mathrm{CH}_{4}$ & 165.4 \\
$\mathrm{~N}_{2} \mathbf{O}$ & 29.96 \\
\hline
\end{tabular}


Appendix 4

Table A4.1: Inputs for each feedstock for pretreatment and pyrolysis

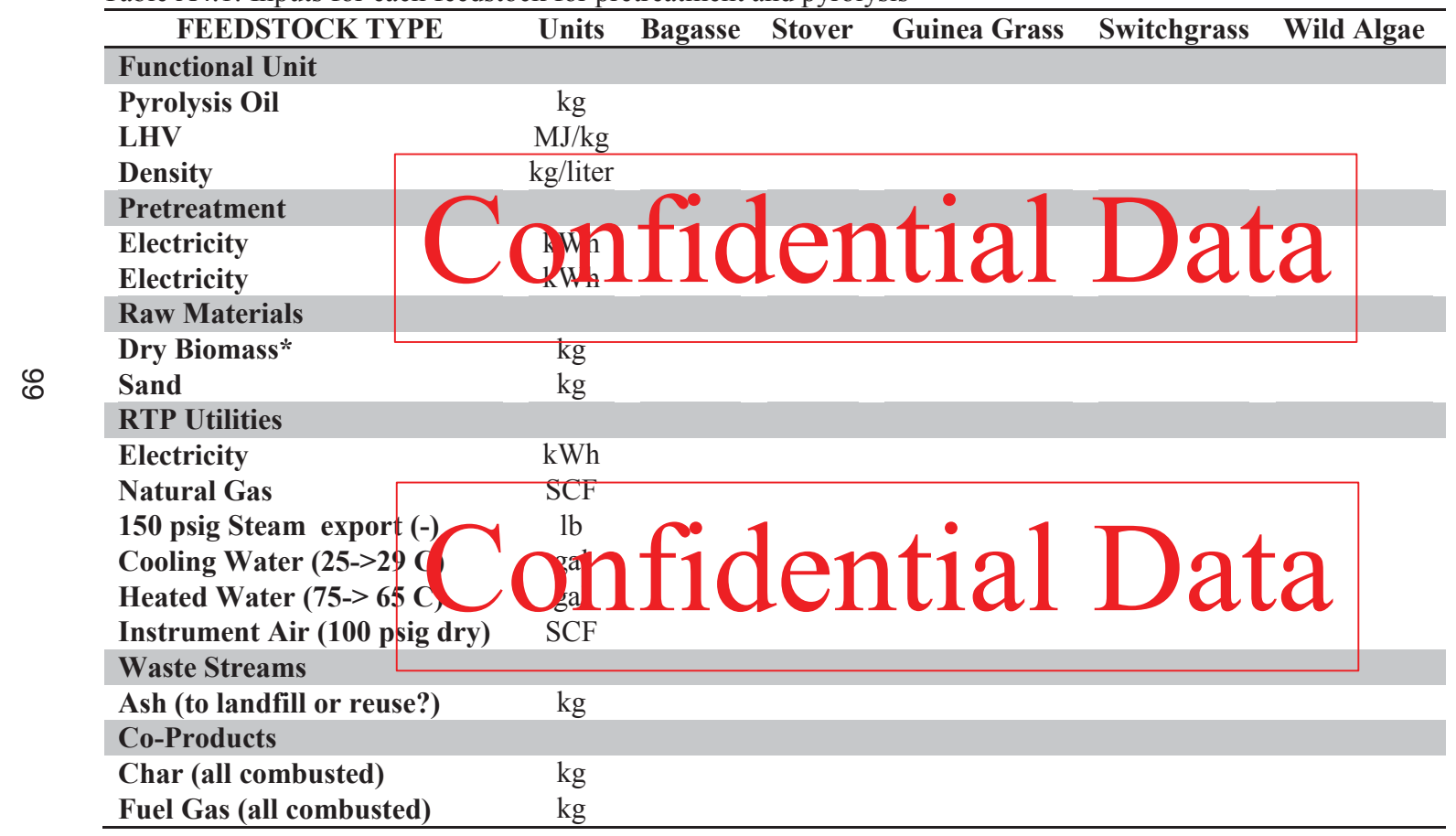


Table A4.1 continued

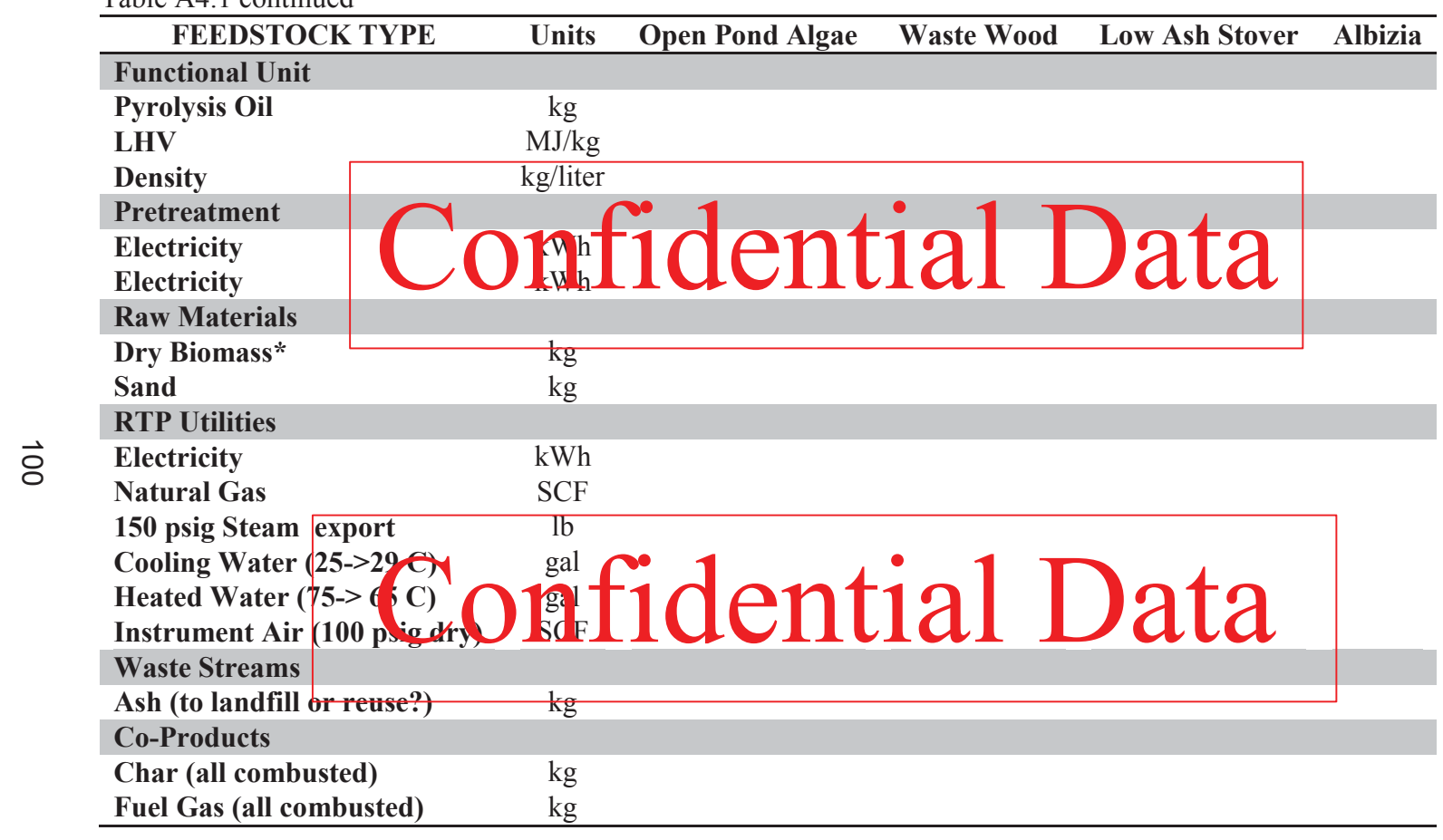


Table A4.2: Inputs for each feedstock for stabilization

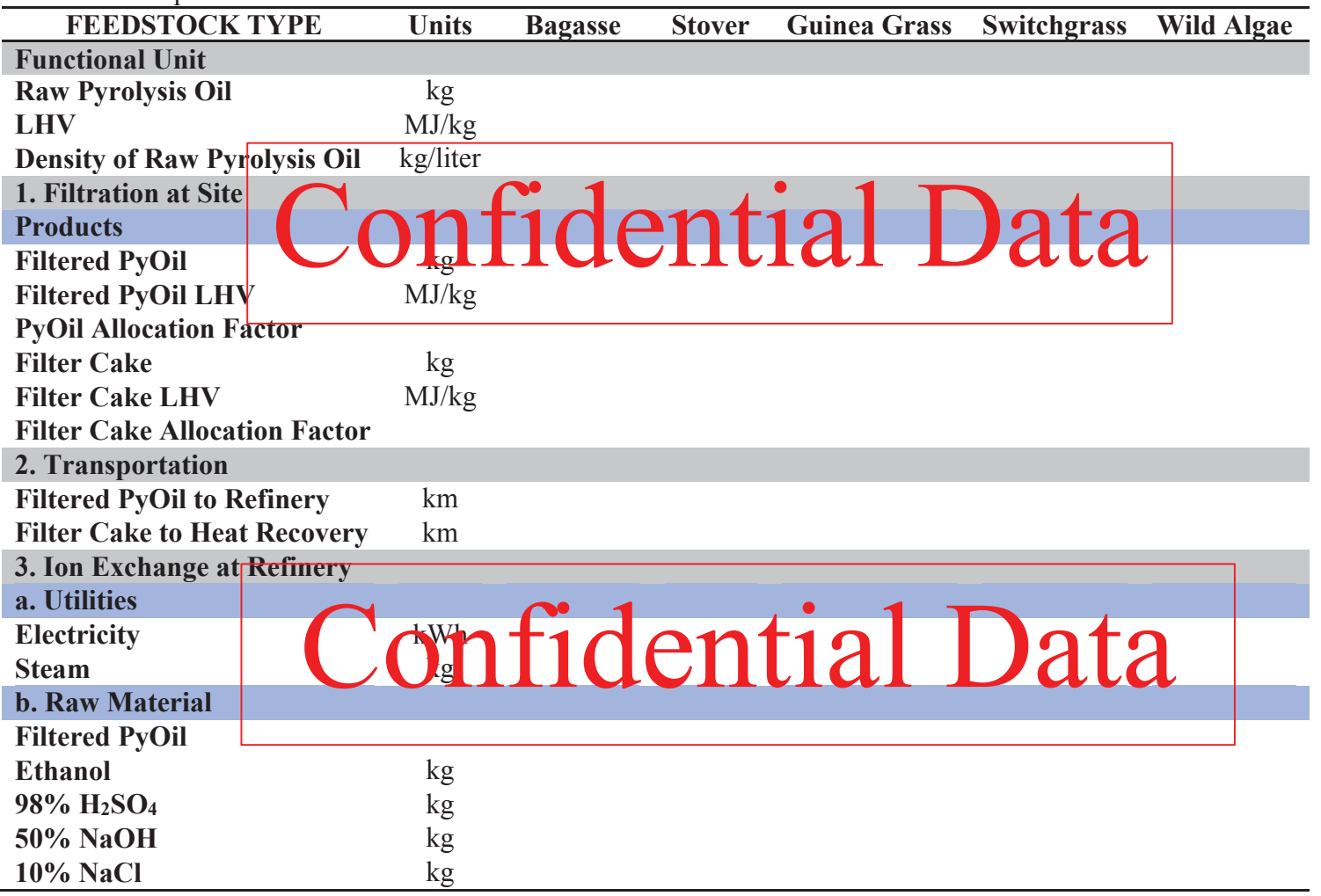




\begin{tabular}{l|l|}
\hline \multicolumn{1}{l}{ Rinse Water } \\
c. Waste Streams \\
Spent Brine to Disposal \\
Products \\
Stabilized PyOil* \\
Stabilized PyOil (NETL) \\
$\begin{array}{l}\text { Stabilized Pyoil LHV } \\
* \text { with ethanol }\end{array}$ \\
\hline
\end{tabular}


Table A4. 2 continued

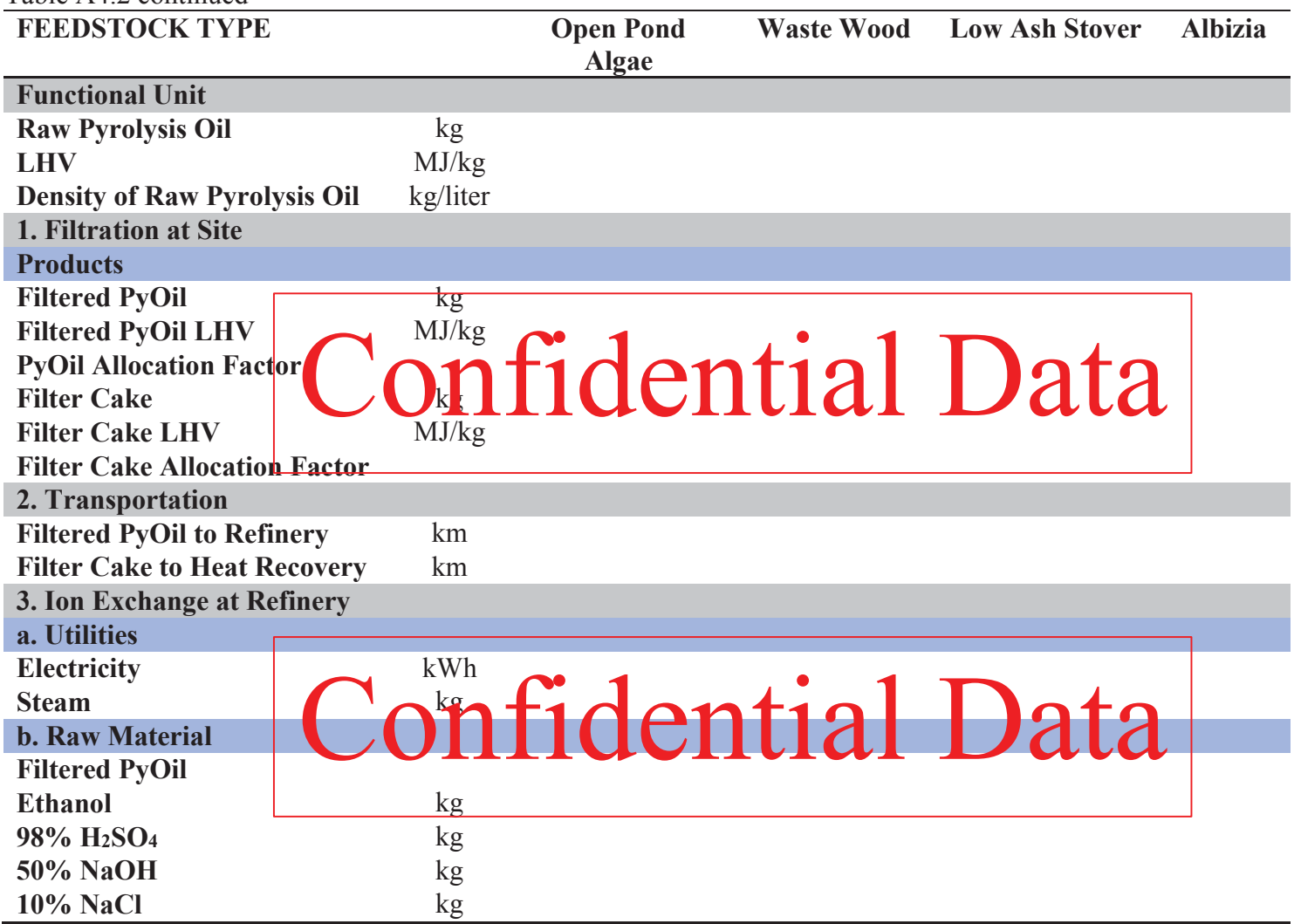


Rinse Water

$\mathrm{kg}$

c. Waste Streams

Spent Brine to Disposal

Prodilized

Stabilized PyO *

Stabilized Pyoil LHV

* with ethanol 


\section{Appendix 5}

Table A5.1a: Upgrading inputs for all feedstocks. $\mathrm{HC}=$ hydrocarbon, $\mathrm{CW}=$ cooling water, $\mathrm{BFW}=$ boiler feed water, Demin. $=$ demineralized, $\mathrm{HP}=$ high pressure.

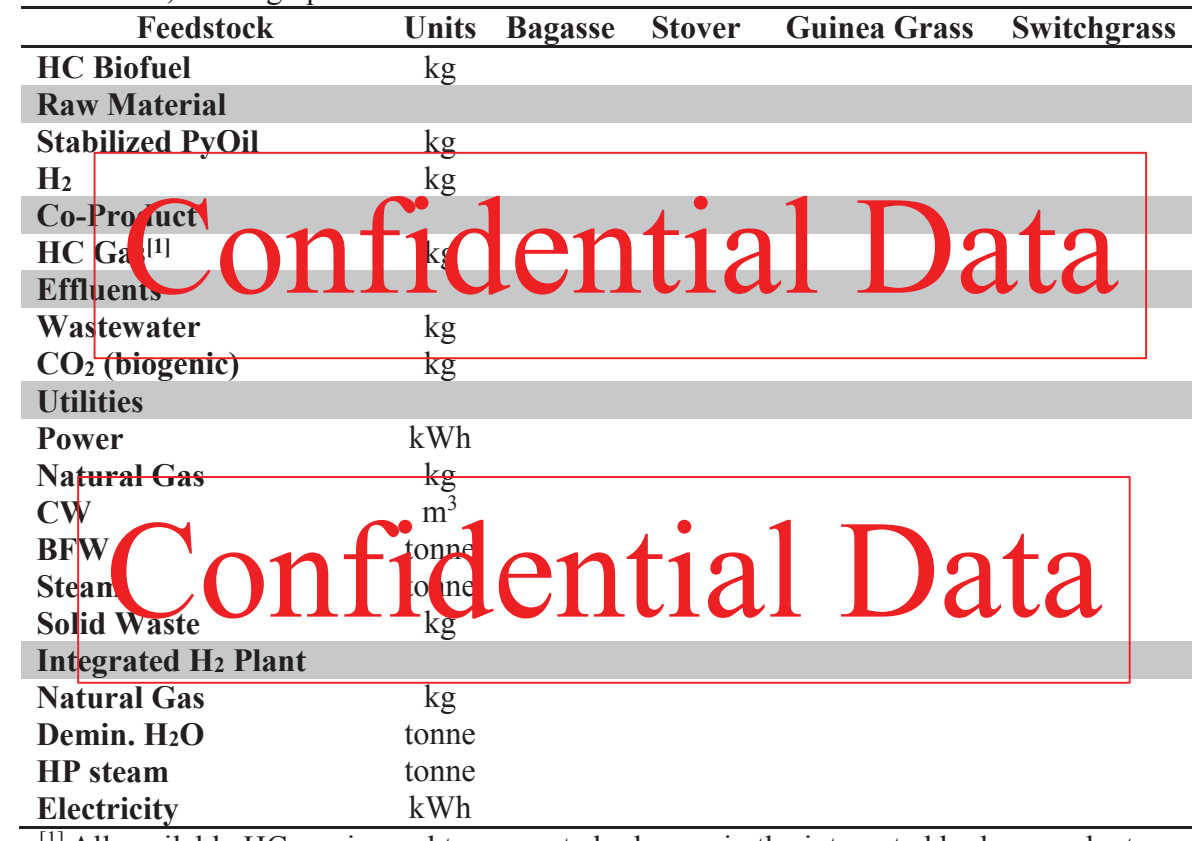

${ }^{[1]}$ All available HC gas is used to generate hydrogen in the integrated hydrogen plant 
Table A5.1b: Upgrading inputs for all feedstock. $\mathrm{HC}=$ hydrocarbon, $\mathrm{CW}=$ cooling water, $\mathrm{BFW}=$ boiler feed water, Demin.$=$ demineralized, $\mathrm{HP}=$ high pressure .

\begin{tabular}{lcccccc}
\hline Feedstock & Units & $\begin{array}{c}\text { Wild } \\
\text { Algae }\end{array}$ & $\begin{array}{c}\text { Open Pond } \\
\text { Algae }\end{array}$ & $\begin{array}{c}\text { Waste } \\
\text { Wood }\end{array}$ & $\begin{array}{c}\text { Low Ash } \\
\text { Corn Stover }\end{array}$ & Albizia \\
\hline
\end{tabular}

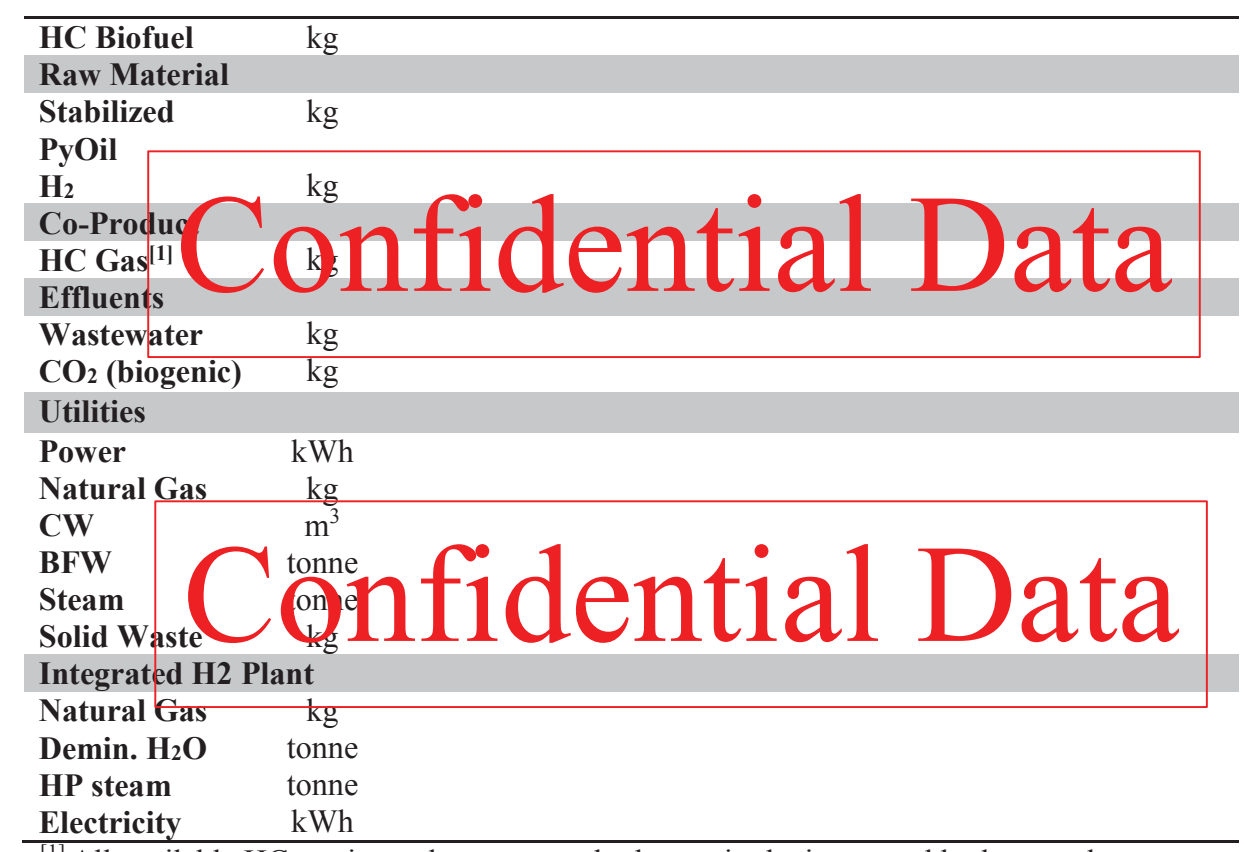

${ }^{[1]}$ All available HC gas is used to generate hydrogen in the integrated hydrogen plant 
Table A5.2a: Water use for each feedstock in gallons of water per $\mathrm{kg}$ of biofuel assuming 2\% and 5\% water consumption for cooling water (CW) and boiler feed water (BFW), respectively

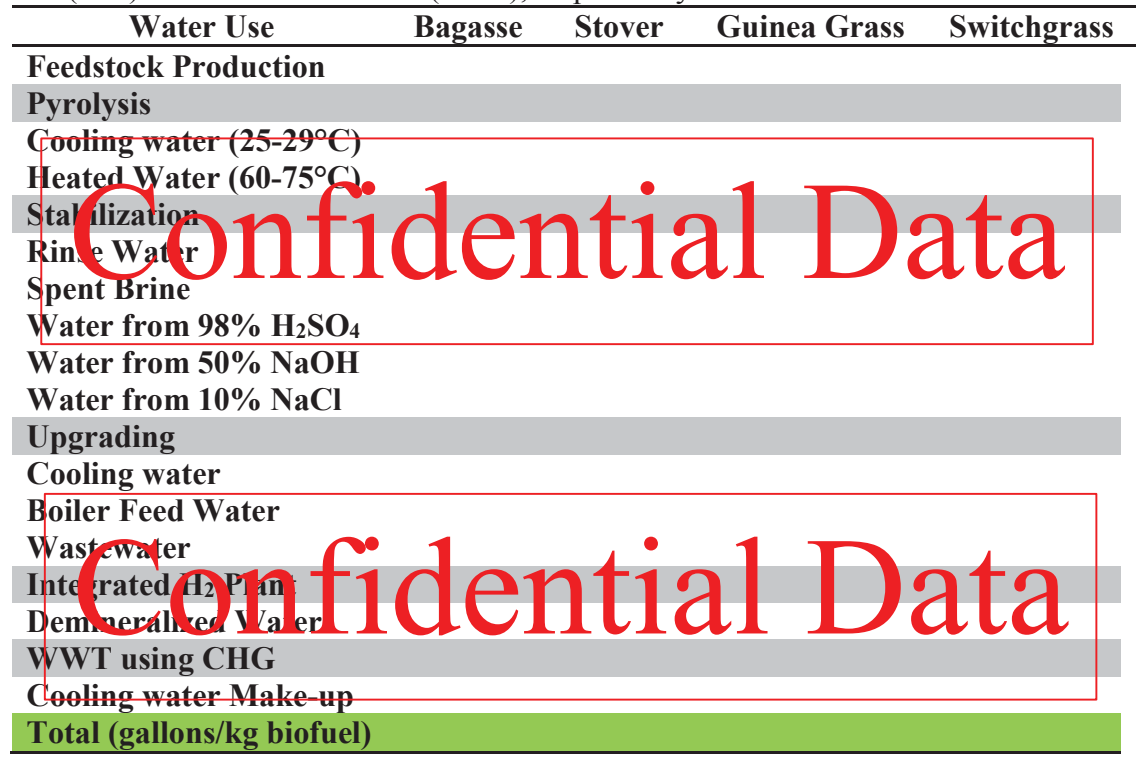


Table A5.2b: Water use for each feedstock in gallons of water per $\mathrm{kg}$ of biofuel assuming 2\% and 5\% water consumption for cooling water $(\mathrm{CW})$ and boiler feed water (BFW) respectively

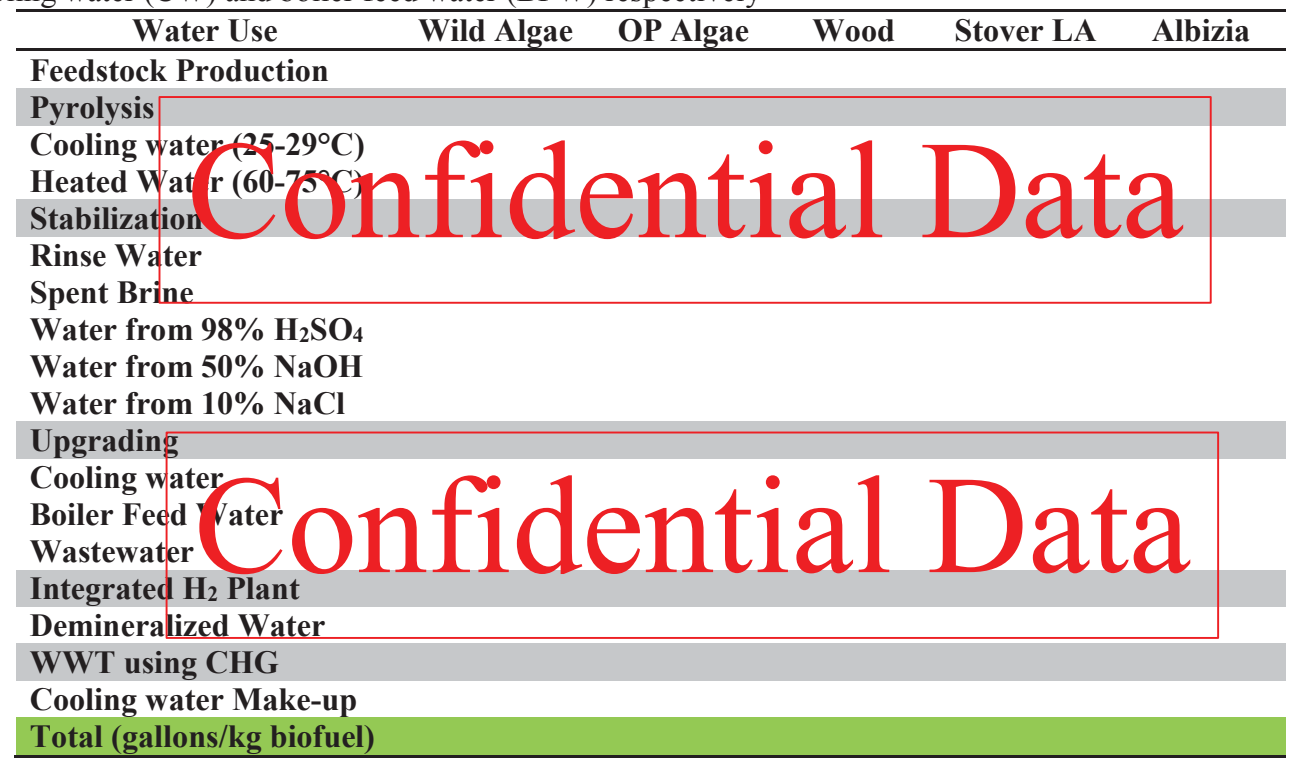




\section{Appendix 6}

Table A6.1: GHG emissions for stabilized pyrolysis oil derived from sugarcane bagasse using both displacement and energy allocation with two functional units of metric tons of stabilized pyrolysis oil and MJ of stabilized pyrolysis oil

\begin{tabular}{lcccc}
\hline \multicolumn{1}{c}{ Bagasse } & $\begin{array}{c}\text { kg/MT } \\
\text { (Displacement) }\end{array}$ & $\begin{array}{c}\text { g/MJ } \\
\text { (Displacement) }\end{array}$ & $\begin{array}{c}\text { kg/MT } \\
\text { (Spatari } \\
\text { et al.) }\end{array}$ & $\begin{array}{c}\text { g/MJ } \\
\text { (Spatari } \\
\text { et al.) }\end{array}$ \\
\hline $\begin{array}{l}\text { Pretreatment } \\
\text { Primary Sizing }\end{array}$ & 19.6 & 0.93 & 17.6 & 0.83 \\
$\begin{array}{l}\text { Secondary Sizing } \\
\text { \& Handling }\end{array}$ & 19.6 & 0.93 & 17.6 & 0.83 \\
Total & 39.1 & 1.85 & 35.1 & 1.66 \\
Pyrolysis & & & & \\
Raw Materials & & & & \\
Bagasse & 29.2 & 1.38 & 26.2 & 1.24 \\
Sand & $7.33 \mathrm{E}-03$ & $3.47 \mathrm{E}-04$ & $6.58 \mathrm{E}-03$ & $3.11 \mathrm{E}-04$ \\
Sand Transport & $5.89 \mathrm{E}-02$ & $2.79 \mathrm{E}-03$ & $5.28 \mathrm{E}-02$ & $2.50 \mathrm{E}-03$ \\
Total & 29.3 & 1.39 & 26.3 & 1.24 \\
RTP Utilities & & & & \\
Natural Gas & $1.79 \mathrm{E}-02$ & $8.49 \mathrm{E}-04$ & $1.61 \mathrm{E}-02$ & $7.62 \mathrm{E}-04$ \\
Water & 3.64 & 0.17 & 3.26 & 0.15 \\
Steam & -116 & -5.47 & & \\
Air & 0.33 & $1.58 \mathrm{E}-02$ & 0.30 & $1.42 \mathrm{E}-02$ \\
Electricity & 174 & 8.25 & 156 & 7.40 \\
Total & 62.8 & 2.97 & 160 & 7.57 \\
Waste Streams & & & & \\
Ash to landfill & 0.34 & $1.61 \mathrm{E}-02$ & 0.31 & $1.45 \mathrm{E}-02$ \\
\hline
\end{tabular}




\begin{tabular}{lcccc}
\hline Total & 0.34 & $1.61 \mathrm{E}-02$ & 0.31 & $1.45 \mathrm{E}-02$ \\
Pyrolysis total & 132 & 6.22 & 222 & 10.5 \\
Filtration & & & & \\
Pyrolysis Oil & 132 & 6.22 & 222 & 10.5 \\
Filter cake & -78.2 & -3.70 & & \\
Transportation & 19.0 & 0.90 & 18.4 & 0.87 \\
Filtration Total & 72.4 & 3.42 & 240 & 11.4 \\
Ion Exchange & & & & \\
Utilities & & & & \\
Electricity & 0.78 & $3.70 \mathrm{E}-02$ & 0.78 & $3.70 \mathrm{E}-02$ \\
Steam & 0.29 & $1.35 \mathrm{E}-02$ & 0.29 & $1.35 \mathrm{E}-02$ \\
Total & 1.07 & $5.05 \mathrm{E}-02$ & 1.07 & $5.05 \mathrm{E}-02$ \\
Raw Materials & & & & \\
Filtered pyoil & 72.4 & 3.42 & 240 & 11.4 \\
Ethanol & 36.1 & 1.71 & 36.1 & 1.71 \\
Sulfuric Acid & 0.84 & 0.04 & 0.84 & 0.04 \\
NaOH & 11.2 & 0.53 & 11.2 & 0.53 \\
NaCl & 1.39 & $6.59 \mathrm{E}-02$ & 1.39 & $6.59 \mathrm{E}-02$ \\
Rinse water & $2.34 \mathrm{E}-03$ & $1.11 \mathrm{E}-04$ & $2.34 \mathrm{E}-03$ & $1.11 \mathrm{E}-04$ \\
Total & 122 & 5.77 & 290 & 13.7 \\
Waste Streams & & & & \\
Spent Brine & $6.62 \mathrm{E}-02$ & $3.13 \mathrm{E}-03$ & $6.62 \mathrm{E}-02$ & $3.13 \mathrm{E}-03$ \\
\hline Stabilized PyOil & 123 & 5.82 & 291 & 13.8 \\
Total & & & & \\
\hline
\end{tabular}


Table A6.2: CED for stabilized pyrolysis oil derived from sugarcane bagasse using displacement allocation with a functional unit of one MJ of stabilized pyrolysis oil

\begin{tabular}{lc}
\hline Cumulative Energy Demand & MJ/MJ \\
\hline Non renewable fossil & $5.52 \mathrm{E}-02$ \\
Non renewable nuclear & $5.05 \mathrm{E}-02$ \\
Non renewable biomass & $3.93 \mathrm{E}-07$ \\
Renewable biomass & 0.941 \\
Renewable others & $2.87 \mathrm{E}-04$ \\
Renewable water & $4.97 \mathrm{E}-03$ \\
Total & 1.05 \\
\hline
\end{tabular}

Table A6.3: FED for stabilized pyrolysis oil derived from sugarcane bagasse using displacement allocation with a functional

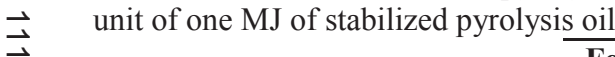

\begin{tabular}{lc}
\hline Fossil Energy Demand & MJ/MJ \\
\hline Electricity & 0.119 \\
Truck transport & $3.42 \mathrm{E}-02$ \\
Ethanol & $1.72 \mathrm{E}-02$ \\
Filter Cake & $-3.55 \mathrm{E}-02$ \\
Steam Credit & $-9.13 \mathrm{E}-02$ \\
Remaining & $1.14 \mathrm{E}-02$ \\
Total & $5.52 \mathrm{E}-02$ \\
\hline
\end{tabular}


Table A6.4: GHG emissions for stabilized pyrolysis oil derived from guinea grass using both displacement and energy allocation with two functional units of metric tons of stabilized pyrolysis oil and MJ of stabilized pyrolysis oil

\begin{tabular}{|c|c|c|c|c|}
\hline Guinea Grass & $\begin{array}{c}\mathrm{kg} / \mathrm{MT} \\
\text { (Displacement) }\end{array}$ & $\begin{array}{c}\mathrm{g} / \mathbf{M J} \\
\text { (Displacement) }\end{array}$ & $\begin{array}{c}\text { kg/MT } \\
\text { (Spatari } \\
\text { et al.) }\end{array}$ & $\begin{array}{c}\text { g/MJ } \\
\text { (Spatari } \\
\text { et al.) }\end{array}$ \\
\hline \multicolumn{5}{|l|}{ Pretreatment } \\
\hline Primary Sizing & 23.1 & 1.26 & 21.5 & 1.17 \\
\hline $\begin{array}{l}\text { Secondary Sizing } \\
\text { \& Handling }\end{array}$ & 19.3 & 1.06 & 18.0 & 0.98 \\
\hline Total & 42.5 & 2.32 & 39.4 & 2.15 \\
\hline \multicolumn{5}{|l|}{ Pyrolysis } \\
\hline \multicolumn{5}{|l|}{ Raw Materials } \\
\hline Guinea Grass & 225 & 12.3 & 209 & 11.4 \\
\hline Sand & 7.72E-03 & $4.22 \mathrm{E}-04$ & 7.17E-03 & $3.92 \mathrm{E}-04$ \\
\hline Sand Transport & $6.21 \mathrm{E}-02$ & 3.39E-03 & $5.77 \mathrm{E}-02$ & $3.15 \mathrm{E}-03$ \\
\hline Total & 225 & 12.3 & 209 & 11.4 \\
\hline \multicolumn{5}{|l|}{ RTP Utilities } \\
\hline Natural Gas & $2.02 \mathrm{E}-02$ & $1.11 \mathrm{E}-03$ & $1.88 \mathrm{E}-02$ & $1.03 \mathrm{E}-03$ \\
\hline Water & 4.11 & 0.22 & 3.81 & 0.21 \\
\hline Steam & -36.3 & -1.98 & & \\
\hline Air & 0.40 & $2.16 \mathrm{E}-02$ & 0.37 & $2.01 \mathrm{E}-02$ \\
\hline Electricity & 182 & 9.96 & 169 & 9.25 \\
\hline Total $\quad 151$ & 8.23 & 174 & 9.48 & \\
\hline \multicolumn{5}{|l|}{ Waste Streams } \\
\hline Ash to landfill & 1.41 & 7.72E-02 & 1.31 & 7.17E-02 \\
\hline Total & 1.41 & $7.72 \mathrm{E}-02$ & 1.31 & 7.17E-02 \\
\hline Pyrolysis total & 420 & 22.9 & 424 & 23.1 \\
\hline \multicolumn{5}{|l|}{ Filtration } \\
\hline Pyrolysis Oil & 420 & 22.9 & 424 & 23.1 \\
\hline
\end{tabular}




\begin{tabular}{llcccc} 
& Filter cake & -81.5 & -4.45 & & \\
Transportation & 18.4 & 1.01 & 17.6 & 0.96 \\
Filtration Total & 357 & 19.5 & 441 & 24.1 \\
Ion Exchange & & & & \\
Utilities & & & & \\
Electricity & 0.21 & $1.14 \mathrm{E}-02$ & 0.21 & $1.14 \mathrm{E}-02$ \\
Steam & 0.73 & $3.98 \mathrm{E}-02$ & 0.73 & 0.04 \\
Total & 0.94 & $5.12 \mathrm{E}-02$ & 0.94 & 0.05 \\
Raw Materials & & & & \\
Filtered pyoil & 357 & 19.5 & 441 & 24.1 \\
Ethanol & 94.2 & 5.15 & 94.2 & 5.15 \\
Sulfuric Acid & 2.17 & 0.12 & 2.17 & 0.12 \\
NaOH & 29.0 & 1.58 & 29.0 & 1.58 \\
NaCl & 3.62 & 0.20 & 3.62 & 0.20 \\
Rinse water & $6.07 \mathrm{E}-03$ & $3.32 \mathrm{E}-04$ & $6.07 \mathrm{E}-03$ & $3.32 \mathrm{E}-04$ \\
\hline Total & 486 & 26.5 & 570 & 31.1 \\
Waste Streams & & & & \\
Spent Brine & 0.17 & $9.40 \mathrm{E}-03$ & 0.17 & $9.40 \mathrm{E}-03$ \\
\hline Stabilized PyOil & 487 & 26.6 & 571 & 31.2 \\
\hline Total & & & &
\end{tabular}


Table A6.5: CED for stabilized pyrolysis oil derived from guinea grass using displacement allocation with a functional unit of one MJ of stabilized pyrolysis oil

\begin{tabular}{lc}
\hline Cumulative Energy Demand & MJ/MJ \\
\hline Non renewable fossil & 0.279 \\
Non renewable nuclear & $7.86 \mathrm{E}-02$ \\
Non renewable biomass & $1.3 \mathrm{E}-06$ \\
Renewable biomass & 1.46 \\
Renewable others & $6.27 \mathrm{E}-04$ \\
Renewable water & $8.73 \mathrm{E}-03$ \\
Total & 1.83 \\
\hline
\end{tabular}

Table A6.6: FED for stabilized pyrolysis oil derived from guinea grass using displacement allocation with a functional unit of one MJ of stabilized pyrolysis oil

\begin{tabular}{lc}
\hline Fossil Energy & MJ/MJ \\
\hline Electricity & 0.144 \\
Ethanol & $5.18 \mathrm{E}-02$ \\
Urea & $3.89 \mathrm{E}-02$ \\
Truck Transport & $3.78 \mathrm{E}-02$ \\
Filter Cake & $-4.26 \mathrm{E}-02$ \\
Steam Credit & $-3.24 \mathrm{E}-02$ \\
Remaining & $8.2 \mathrm{E}-02$ \\
Total & 0.279 \\
\hline
\end{tabular}


Table A6.7: GHG emissions for stabilized pyrolysis oil derived from open pond algae using both displacement and energy allocation with two functional units of metric tons of stabilized pyrolysis oil and MJ of stabilized pyrolysis oil

\begin{tabular}{lllll}
\hline Open Pond Algae & $\begin{array}{l}\mathrm{kg} / \mathrm{MT} \\
\text { (Displacement) }\end{array}$ & $\begin{array}{l}\mathrm{g} / \mathrm{MJ} \\
\text { (Displacement) }\end{array}$ & $\begin{array}{l}\mathrm{kg} / \mathrm{MT} \text { (Spatari } \\
\text { et al.) }\end{array}$ & $\begin{array}{l}\mathrm{g} / \mathrm{MJ} \\
\text { (Spatari et al.) }\end{array}$ \\
\hline $\begin{array}{l}\text { Pyrolysis Oil } \\
\text { Pretreatment }\end{array}$ & & & \\
Sizing \& Handling & 63.2 & 2.56 & 55.0 & 2.22 \\
Total & 63.2 & 2.56 & 55.0 & 2.22 \\
Raw Materials & & & & \\
Open Pond Algae & 637 & 25.8 & 537 & 21.7 \\
$\begin{array}{l}\text { Open Pond Algae } \\
\text { (75\% recycle) }\end{array}$ & 513 & 20.7 & 429 & 17.4 \\
Sand & $9.38 \mathrm{E}-03$ & $3.79 \mathrm{E}-04$ & $8.16 \mathrm{E}-03$ & $3.30 \mathrm{E}-04$ \\
Sand Transport & $8.14 \mathrm{E}-02$ & $3.29 \mathrm{E}-03$ & $7.08 \mathrm{E}-02$ & $2.86 \mathrm{E}-03$ \\
Total & 513 & 20.7 & 537 & 21.7 \\
Total (75\% recycle) & 637 & 25.8 & 429 & 17.4 \\
RTP Utilities & & & & \\
Natural Gas & $2.20 \mathrm{E}-02$ & $8.91 \mathrm{E}-04$ & $1.92 \mathrm{E}-02$ & $7.75 \mathrm{E}-04$ \\
Water & 3.64 & 0.15 & 3.17 & 0.13 \\
$\begin{array}{l}\text { Steam } \\
\text { Air }\end{array}$ & -176 & -7.13 & & \\
Electricity & 0.34 & $1.36 \mathrm{E}-02$ & 0.29 & $1.19 \mathrm{E}-02$ \\
Total & 202 & 8.16 & 176 & 7.10 \\
Waste Streams & 29.6 & 1.20 & 179 & 7.24 \\
Ash to landfill & 0.86 & $3.49 \mathrm{E}-02$ & 0.75 & $3.04 \mathrm{E}-02$ \\
Total & 0.86 & $3.49 \mathrm{E}-02$ & 0.75 & $3.04 \mathrm{E}-02$ \\
Pyrolysis Total & 731 & 29.5 & 772 & 31.2 \\
Pyrolysis Total (75\% & 607 & 24.5 & 664 & 26.9 \\
recycle) & & & & \\
\hline & & & & \\
\hline
\end{tabular}




\begin{tabular}{|c|c|c|c|c|}
\hline \multicolumn{5}{|l|}{ Filtration } \\
\hline Pyrolysis Oil & 731 & 29.5 & 772 & 31.2 \\
\hline Filter cake & -122 & -4.93 & & \\
\hline Transportation & 18.9 & 0.77 & 18.0 & 0.73 \\
\hline Filtration Total & 628 & 25.4 & 790 & 31.9 \\
\hline $\begin{array}{l}\text { Filtration Total } \\
\text { (75\% recycle) }\end{array}$ & 504 & 20.4 & 682 & 27.6 \\
\hline \multicolumn{5}{|l|}{ Ion Exchange } \\
\hline \multicolumn{5}{|l|}{ Utilities } \\
\hline Electricity & 0.10 & 4.17E-03 & 0.10 & 4.17E-03 \\
\hline Steam & 0.36 & $1.46 \mathrm{E}-02$ & 0.36 & $1.46 \mathrm{E}-02$ \\
\hline Total & 0.46 & $1.87 \mathrm{E}-02$ & 0.46 & $1.87 \mathrm{E}-02$ \\
\hline \multicolumn{5}{|l|}{ Raw Materials } \\
\hline Filtered pyoil & 628 & 25.4 & 790 & 31.9 \\
\hline Ethanol & 46.5 & 1.88 & 46.5 & 1.88 \\
\hline Sulfuric Acid & 1.07 & 4.33E-02 & 1.07 & 4.33E-02 \\
\hline $\mathrm{NaOH}$ & 14.4 & 0.58 & 14.4 & 0.58 \\
\hline $\mathrm{NaCl}$ & 1.79 & $7.25 \mathrm{E}-02$ & 1.79 & $7.25 \mathrm{E}-02$ \\
\hline Rinse water & $2.99 \mathrm{E}-03$ & $1.21 \mathrm{E}-04$ & $2.99 \mathrm{E}-03$ & $1.21 \mathrm{E}-04$ \\
\hline Total & 691 & 28.0 & 854 & 34.5 \\
\hline $\begin{array}{l}\text { Waste Streams } \\
\text { Spent Brine }\end{array}$ & $8.48 \mathrm{E}-02$ & $3.43 \mathrm{E}-03$ & $8.48 \mathrm{E}-02$ & $3.43 \mathrm{E}-03$ \\
\hline $\begin{array}{l}\text { Stabilized PyOil } \\
\text { Total }\end{array}$ & 692 & 28.0 & 854 & 34.5 \\
\hline $\begin{array}{l}\text { Stabilized PyOil } \\
\text { Total ( } 75 \% \text { recycle) }\end{array}$ & 568 & 23.0 & 746 & 30.2 \\
\hline
\end{tabular}


Table A6.8: CED for stabilized pyrolysis oil derived from open pond algae using displacement allocation and assuming no nutrient recycle with a functional unit of one $\mathrm{MJ}$ of stabilized pyrolysis oil

\begin{tabular}{lc}
\hline Cumulative Energy Demand & MJ/MJ \\
\hline Non renewable fossil & 0.472 \\
Non renewable nuclear & 0.154 \\
Non renewable biomass & $3.03 \mathrm{E}-05$ \\
Renewable biomass & 1.22 \\
Renewable others & $1.18 \mathrm{E}-03$ \\
Renewable water & $1.65 \mathrm{E}-02$ \\
Total & 1.87 \\
\hline
\end{tabular}

Table A6.9: FED for stabilized pyrolysis oil derived from open pond algae using displacement allocation and assuming no nutrient recycle with a functional unit of one $\mathrm{MJ}$ of stabilized pyrolysis oil

\begin{tabular}{lc}
\hline Fossil Energy & MJ/MJ \\
\hline Electricity & 0.319 \\
Ammonium nitrate & 0.171 \\
Phosphate & $5.85 \mathrm{E}-02$ \\
Potassium & $3.7 \mathrm{E}-02$ \\
Ethanol & $1.89 \mathrm{E}-02$ \\
Truck Transport & $2.50 \mathrm{E}-02$ \\
Filter Cake & $-4.74 \mathrm{E}-02$ \\
Steam Credit & -0.119 \\
Remaining & $1.01 \mathrm{E}-02$ \\
Total & 0.472 \\
\hline
\end{tabular}


Table A6.10: GHG emissions for stabilized pyrolysis oil derived from corn stover using both displacement and energy allocation with two functional units of metric tons of stabilized pyrolysis oil and MJ of stabilized pyrolysis oil

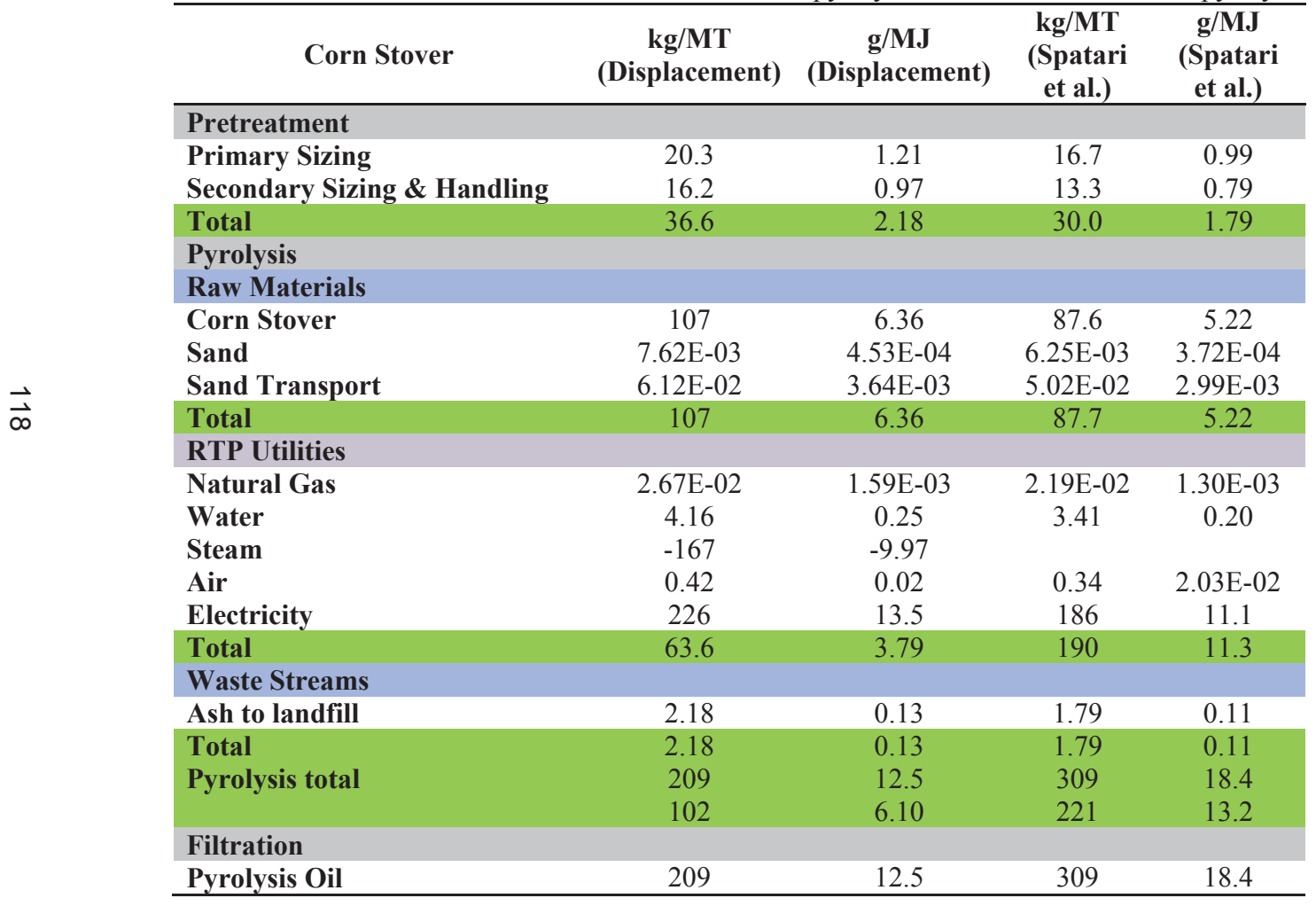




\begin{tabular}{|c|c|c|c|c|c|}
\hline & Filter cake & -128 & -7.64 & & \\
\hline & Transportation & 19.0 & 1.13 & 17.7 & 1.05 \\
\hline & Filtration Total & 99.8 & 5.94 & 327 & 19.5 \\
\hline & Ion Exchange & & & & \\
\hline & Utilities & & & & \\
\hline & Electricity & 0.89 & $5.32 \mathrm{E}-02$ & 0.89 & $5.32 \mathrm{E}-02$ \\
\hline & Steam & 0.30 & $1.76 \mathrm{E}-02$ & 0.30 & $1.76 \mathrm{E}-02$ \\
\hline & Total & 1.19 & $7.08 \mathrm{E}-02$ & 1.19 & 7.08E-02 \\
\hline \multirow{11}{*}{$\overrightarrow{\overrightarrow{0}}$} & Raw Materials & & & & \\
\hline & Filtered pyoil & 99.8 & 5.94 & 327 & 19.5 \\
\hline & Ethanol & 38.8 & 2.31 & 38.8 & 2.31 \\
\hline & Sulfuric Acid & 0.90 & $5.34 \mathrm{E}-02$ & 0.90 & $5.34 \mathrm{E}-02$ \\
\hline & $\mathrm{NaOH}$ & 12.0 & 0.71 & 12.0 & 0.71 \\
\hline & $\mathrm{NaCl}$ & 1.50 & 8.94E-02 & 1.50 & 8.94E-02 \\
\hline & Rinse water & $2.50 \mathrm{E}-03$ & $1.49 \mathrm{E}-04$ & $2.50 \mathrm{E}-03$ & $1.49 \mathrm{E}-04$ \\
\hline & Total & 153 & 9.11 & 380 & 22.6 \\
\hline & Waste Streams & & & & \\
\hline & Spent Brine & 7.09E-02 & $4.22 \mathrm{E}-03$ & 7.09E-02 & $4.22 \mathrm{E}-03$ \\
\hline & Stabilized PyOil Total & 154 & 9.19 & 381 & 22.7 \\
\hline
\end{tabular}


Table A6.11: CED for stabilized pyrolysis oil derived from corn stover using displacement allocation with a functional unit of one MJ of stabilized pyrolysis oil

\begin{tabular}{lc}
\hline Cumulative Energy Demand & MJ/MJ \\
\hline Non renewable fossil & 0.100 \\
Non renewable nuclear & $7.92 \mathrm{E}-02$ \\
Non renewable biomass & $5.92 \mathrm{E}-06$ \\
Renewable biomass & 1.77 \\
Renewable others & $4.85 \mathrm{E}-04$ \\
Renewable water & $7.92 \mathrm{E}-03$ \\
Total & 1.96 \\
\hline
\end{tabular}

Table A6.12: FED for stabilized pyrolysis oil derived from corn stover using displacement allocation with a functional unit $\overrightarrow{\mathrm{O}}$ of one

\begin{tabular}{lc}
\hline Fossil Energy & MJ/MJ \\
\hline Electricity & 0.184 \\
Ammonia & $3.96 \mathrm{E}-02$ \\
Diesel & $2.87 \mathrm{E}-02$ \\
Potassium & $2.78 \mathrm{E}-02$ \\
Ethanol & $2.32 \mathrm{E}-02$ \\
Truck Transport & $1.79 \mathrm{E}-02$ \\
Filter Cake & $-7.33 \mathrm{E}-02$ \\
Steam Credit & -0.167 \\
Remaining & $1.91 \mathrm{E}-02$ \\
Total & 0.100 \\
\hline
\end{tabular}


Table A6.13 GHG emissions for stabilized pyrolysis oil derived from low ash corn stover using both displacement and energy allocation with two functional units of metric tons of stabilized pyrolysis oil and MJ of stabilized pyrolysis oil

\begin{tabular}{|c|c|c|c|c|}
\hline LA Corn Stover & $\begin{array}{c}\mathrm{kg} / \mathrm{MT} \\
\text { (Displacement) }\end{array}$ & $\begin{array}{c}\text { g/MJ } \\
\text { (Displacement) }\end{array}$ & $\begin{array}{c}\mathrm{kg} / \mathrm{MT} \\
\text { (Spatari } \\
\text { et al.) }\end{array}$ & $\begin{array}{c}\text { g/MJ } \\
\text { (Spatari } \\
\text { et al.) }\end{array}$ \\
\hline \multicolumn{5}{|l|}{ Pretreatment } \\
\hline \multirow{2}{*}{$\begin{array}{l}\text { Primary Sizing } \\
\text { Secondary Sizing } \\
\text { \& Handling }\end{array}$} & 20.0 & 1.26 & 14.5 & 0.92 \\
\hline & 15.9 & 1.01 & 11.6 & 0.73 \\
\hline Total & 35.9 & 2.27 & 26.1 & 1.65 \\
\hline \multicolumn{5}{|l|}{ Pyrolysis } \\
\hline \multicolumn{5}{|l|}{ Raw Materials } \\
\hline LA Corn Stover & 101 & 6.40 & 73.4 & 4.64 \\
\hline Sand & $1.67 \mathrm{E}-02$ & $1.05 \mathrm{E}-03$ & $1.21 \mathrm{E}-02$ & 7.65E-04 \\
\hline Sand Transport & 0.13 & $8.52 \mathrm{E}-03$ & 0.10 & $6.18 \mathrm{E}-03$ \\
\hline Total & 101 & 6.41 & 73.5 & 4.65 \\
\hline \multicolumn{5}{|l|}{ RTP Utilities } \\
\hline Natural Gas & $2.88 \mathrm{E}-02$ & $1.82 \mathrm{E}-03$ & $2.09 \mathrm{E}-02$ & $1.32 \mathrm{E}-03$ \\
\hline Water & 4.04 & 0.26 & 2.93 & 0.19 \\
\hline Steam & -324 & -20.5 & & \\
\hline Air & 0.37 & $2.37 \mathrm{E}-02$ & 0.27 & $1.72 \mathrm{E}-02$ \\
\hline Electricity & 249 & 15.8 & 181 & 11.5 \\
\hline Total & -70.1 & -4.44 & 184 & 11.7 \\
\hline \multicolumn{5}{|l|}{ Waste Streams } \\
\hline Ash to landfill & 0.54 & $3.45 \mathrm{E}-02$ & 0.39 & $2.50 \mathrm{E}-02$ \\
\hline Total & 0.54 & $3.45 \mathrm{E}-02$ & 0.39 & $2.50 \mathrm{E}-02$ \\
\hline \multirow[t]{2}{*}{ Pyrolysis total } & 67.7 & 4.28 & 284 & 18.0 \\
\hline & & & 211 & 13.3 \\
\hline Filtration & & & & \\
\hline
\end{tabular}




\begin{tabular}{lcccc}
\hline Pyrolysis Oil & 67.7 & 4.28 & 284 & 17.98 \\
$\begin{array}{l}\text { Filter cake } \\
\text { Transportation }\end{array}$ & -103 & -6.51 & & \\
Filtration Total & 19.2 & 1.22 & 18.1 & 1.14 \\
& -16.1 & -1.02 & 302 & 19.1 \\
Ion Exchange & & & & \\
Utilities & & & & \\
Electricity & $3.99 \mathrm{E}-02$ & $2.53 \mathrm{E}-03$ & $3.99 \mathrm{E}-02$ & $2.53 \mathrm{E}-03$ \\
Steam & 0.15 & $9.24 \mathrm{E}-03$ & 0.15 & $9.24 \mathrm{E}-03$ \\
Total & 0.19 & $1.18 \mathrm{E}-02$ & 0.19 & $1.18 \mathrm{E}-02$ \\
Raw Materials & & & & \\
Filtered pyoil & -16.1 & -1.02 & 302 & 19.1 \\
Ethanol & 19.7 & 1.25 & 19.7 & 1.25 \\
Sulfuric Acid & 0.19 & $1.22 \mathrm{E}-02$ & 0.19 & $1.22 \mathrm{E}-02$ \\
NaOH & 2.61 & 0.17 & 2.61 & 0.17 \\
NaCl & 0.33 & $2.07 \mathrm{E}-02$ & 0.33 & $2.07 \mathrm{E}-02$ \\
Rinse water & $5.45 \mathrm{E}-04$ & $3.45 \mathrm{E}-05$ & $5.45 \mathrm{E}-04$ & $3.45 \mathrm{E}-05$ \\
Total & 6.76 & 0.43 & 325 & 20.6 \\
Waste Streams & & & & \\
Spent Brine & $1.54 \mathrm{E}-02$ & $9.75 \mathrm{E}-04$ & $1.54 \mathrm{E}-02$ & $9.75 \mathrm{E}-04$ \\
Stabilized PyOil & 6.96 & 0.44 & 325 & 20.6 \\
Total & & & & \\
\hline & & & & \\
\hline
\end{tabular}


Table A6.14: CED for stabilized pyrolysis oil derived from low ash corn stover using displacement allocation with a functional unit of one $\mathrm{MJ}$ of stabilized pyrolysis oil

\begin{tabular}{lc}
\hline Cumulative Energy Demand & MJ/MJ \\
\hline Non renewable fossil & $-5.03 \mathrm{E}-02$ \\
Non renewable nuclear & $7.78 \mathrm{E}-02$ \\
Non renewable biomass & $5.26 \mathrm{E}-06$ \\
Renewable biomass & 1.65 \\
Renewable others & $3.93 \mathrm{E}-04$ \\
Renewable water & $7.35 \mathrm{E}-03$ \\
Total & 1.68 \\
\hline
\end{tabular}

Table A6.15: FED for stabilized pyrolysis oil derived from low ash corn stover using displacement allocation with a functional unit of one MJ of stabilized pyrolysis oil

\begin{tabular}{lc}
\hline Fossil Energy Demand & MJ/MJ \\
\hline Electricity & 0.199 \\
Ammonia & $3.75 \mathrm{E}-02$ \\
Diesel & $2.72 \mathrm{E}-02$ \\
Potassium & $2.63 \mathrm{E}-02$ \\
Truck Transport & $1.81 \mathrm{E}-02$ \\
Ethanol & $1.18 \mathrm{E}-02$ \\
Phosphate & $5.37 \mathrm{E}-03$ \\
Filter Cake & $-5.89 \mathrm{E}-02$ \\
Steam Credit & -0.322 \\
Remaining & $5.18 \mathrm{E}-03$ \\
Total & $-5.03 \mathrm{E}-02$ \\
\hline
\end{tabular}


Table A6.16: GHG emissions for stabilized pyrolysis oil derived from switchgrass using both displacement and energy allocation with two functional units of metric tons of stabilized pyrolysis oil and MJ of stabilized pyrolysis oil

\begin{tabular}{lcccc}
\hline \multicolumn{1}{c}{ Switchgrass } & $\begin{array}{c}\text { kg/MT } \\
\text { (Displacement) }\end{array}$ & $\begin{array}{c}\text { g/MJ } \\
\text { (Displacement) }\end{array}$ & $\begin{array}{c}\text { kg/MT } \\
\text { (Spatari } \\
\text { et al.) }\end{array}$ & $\begin{array}{c}\text { g/MJ } \\
\text { (Spatari } \\
\text { et al.) }\end{array}$ \\
\hline $\begin{array}{l}\text { Pretreatment } \\
\text { Primary Sizing }\end{array}$ & 23.6 & 1.46 & 20.0 & 1.24 \\
$\begin{array}{l}\text { Secondary Sizing } \\
\text { \& Handling }\end{array}$ & 19.7 & 1.22 & 16.7 & 1.04 \\
Total & 43.3 & 2.68 & 36.8 & 2.28 \\
Pyrolysis & & & & \\
Raw Materials & & & & \\
Switchgrass & 194 & 12.03 & 165 & 10.2 \\
Sand & $6.64 \mathrm{E}-03$ & $4.11 \mathrm{E}-04$ & $5.63 \mathrm{E}-03$ & $3.49 \mathrm{E}-04$ \\
Sand Transport & $5.34 \mathrm{E}-02$ & $3.31 \mathrm{E}-03$ & $4.53 \mathrm{E}-02$ & $2.81 \mathrm{E}-03$ \\
\hline $\begin{array}{l}\text { Total } \\
\text { RTP Utilities }\end{array}$ & 194 & 12.0 & 165 & 10.2 \\
Natural Gas & $2.06 \mathrm{E}-02$ & $1.28 \mathrm{E}-03$ & $1.75 \mathrm{E}-02$ & $1.08 \mathrm{E}-03$ \\
Water & 3.69 & 0.23 & 3.13 & 0.19 \\
Steam & -147 & -9.10 & & \\
Air & 0.34 & $2.08 \mathrm{E}-02$ & 0.29 & $1.77 \mathrm{E}-02$ \\
Electricity & 187 & 11.6 & 159 & 9.82 \\
Total & 43.9 & 2.71 & 162 & 10.0 \\
Waste Streams & & & & \\
\hline $\begin{array}{l}\text { Ash to landfill } \\
\text { Total }\end{array}$ & 0.48 & $2.98 \mathrm{E}-02$ & 0.41 & $2.53 \mathrm{E}-02$ \\
Pyrolysis total & 0.48 & $2.98 \mathrm{E}-02$ & 0.41 & $2.53 \mathrm{E}-02$ \\
Filtration & 282 & 17.5 & 364 & 22.5 \\
Pyrolysis Oil & & & & \\
\hline & 282 & 17.5 & 364 & 22.5 \\
\hline
\end{tabular}




\begin{tabular}{lcccc}
\hline Filter cake & -81.4 & -5.04 & & \\
Transportation & 19.0 & 1.18 & 18.1 & 1.12 \\
Filtration Total & 220 & 13.6 & 382 & 23.7 \\
Ion Exchange & & & & \\
Utilities & & & & \\
Electricity & $7.87 \mathrm{E}-02$ & $4.87 \mathrm{E}-03$ & 0.08 & $4.87 \mathrm{E}-03$ \\
Steam & 0.29 & $1.78 \mathrm{E}-02$ & 0.29 & $1.78 \mathrm{E}-02$ \\
Total & 0.37 & $2.26 \mathrm{E}-02$ & 0.37 & $2.26 \mathrm{E}-02$ \\
Raw Materials & & & & \\
Filtered pyoil & 220 & 13.6 & 382 & 23.7 \\
Ethanol & 36.2 & 2.24 & 36.2 & 2.24 \\
Sulfuric Acid & 0.83 & $5.14 \mathrm{E}-02$ & 0.83 & $5.14 \mathrm{E}-02$ \\
NaOH & 11.1 & 0.69 & 11.1 & 0.69 \\
NaCl & 1.40 & $8.68 \mathrm{E}-02$ & 1.40 & $8.68 \mathrm{E}-02$ \\
Rinse water & $2.34 \mathrm{E}-03$ & $1.45 \mathrm{E}-04$ & $2.34 \mathrm{E}-03$ & $1.45 \mathrm{E}-04$ \\
Total & 269 & 16.7 & 432 & 26.7 \\
Waste Streams & & & & \\
Spent Brine & $6.61 \mathrm{E}-02$ & $4.09 \mathrm{E}-03$ & $6.61 \mathrm{E}-02$ & $4.09 \mathrm{E}-03$ \\
Stabilized PyOil & 270 & 16.7 & 432 & 26.8 \\
Total & & & & \\
\hline
\end{tabular}


Table A6.17: CED for stabilized pyrolysis oil derived from switchgrass using displacement allocation with a functional unit of one MJ of stabilized pyrolysis oil

\begin{tabular}{lc}
\hline Cumulative Energy Demand & MJ/MJ \\
\hline Non renewable fossil & 0.135 \\
Non renewable nuclear & $7.75 \mathrm{E}-02$ \\
Non renewable biomass & $1.08 \mathrm{E}-05$ \\
Renewable biomass & 1.50 \\
Renewable others & $4.85 \mathrm{E}-04$ \\
Renewable water & $8.59 \mathrm{E}-03$ \\
Total & 1.72 \\
\hline
\end{tabular}

Table A6.18: FED for stabilized pyrolysis oil derived from switchgrass using displacement allocation with a functional unit of one MJ of stabilized pyrolysis oil

\begin{tabular}{lc}
\hline Fossil Energy Demand & MJ/MJ \\
\hline Electricity & 0.167 \\
Diesel & $4.64 \mathrm{E}-02$ \\
Truck Transport & $3.16 \mathrm{E}-02$ \\
Ethanol & $2.26 \mathrm{E}-02$ \\
Potassium & $1.28 \mathrm{E}-02$ \\
Phosphate & $1.11 \mathrm{E}-02$ \\
Filter Cake & $-4.83 \mathrm{E}-02$ \\
Steam Credit & -0.151 \\
Remaining & $4.32 \mathrm{E}-02$ \\
Total & 0.135 \\
\hline
\end{tabular}


Table A6.19: GHG emissions for stabilized pyrolysis oil derived from waste wood using both displacement and energy allocation with two functional units of metric tons of stabilized pyrolysis oil and MJ of stabilized pyrolysis oil

\begin{tabular}{|c|c|c|c|c|}
\hline Waste Wood & $\begin{array}{c}\text { kg/MT } \\
\text { (Displacement) }\end{array}$ & $\begin{array}{c}\text { g/MJ } \\
\text { (Displacement) }\end{array}$ & $\begin{array}{c}\text { kg/MT } \\
\text { (Spatari } \\
\text { et al.) }\end{array}$ & $\begin{array}{c}\text { g/MJ } \\
\text { (Spatari } \\
\text { et al.) }\end{array}$ \\
\hline \multicolumn{5}{|l|}{ Pretreatment } \\
\hline Primary Sizing & 23.6 & 1.42 & 18.7 & 1.12 \\
\hline $\begin{array}{l}\text { Secondary Sizing } \\
\text { \& Handling }\end{array}$ & 19.8 & 1.19 & 15.6 & 0.94 \\
\hline Total & 43.4 & 2.60 & 34.3 & 2.06 \\
\hline \multicolumn{5}{|l|}{ Pyrolysis } \\
\hline \multicolumn{5}{|l|}{ Raw Materials } \\
\hline Waste Wood & 67.5 & 4.05 & 53.3 & 3.20 \\
\hline Sand & $1.65 \mathrm{E}-02$ & 9.89E-04 & $1.30 \mathrm{E}-02$ & 7.81E-04 \\
\hline Sand Transport & 0.13 & 7.99E-03 & 0.11 & $6.31 \mathrm{E}-03$ \\
\hline Total & 67.6 & 4.06 & 53.4 & 3.21 \\
\hline \multicolumn{5}{|l|}{ RTP Utilities } \\
\hline Natural Gas & $3.23 \mathrm{E}-02$ & $1.94 \mathrm{E}-03$ & $2.55 \mathrm{E}-02$ & $1.53 \mathrm{E}-03$ \\
\hline Water & 4.02 & 0.24 & 3.18 & 0.19 \\
\hline Steam & -252 & -15.1 & & \\
\hline Air & 0.40 & $2.43 \mathrm{E}-02$ & 0.32 & $1.92 \mathrm{E}-02$ \\
\hline Electricity & 269 & 16.2 & 213 & 12.8 \\
\hline Total & 21.9 & 1.31 & 216 & 13.0 \\
\hline \multicolumn{5}{|l|}{ Waste Streams } \\
\hline Ash to landfill & 0.29 & $1.73 \mathrm{E}-02$ & 0.23 & $1.36 \mathrm{E}-02$ \\
\hline Total & 0.29 & $1.73 \mathrm{E}-02$ & 0.23 & $1.36 \mathrm{E}-02$ \\
\hline Pyrolysis total & 133 & 7.99 & 304 & 18.2 \\
\hline \multicolumn{5}{|l|}{ Filtration } \\
\hline Pyrolysis Oil & 133 & 7.99 & 304 & 18.2 \\
\hline
\end{tabular}




\begin{tabular}{lcccc}
\hline Filter cake & -89.1 & -5.35 & & \\
Transportation & 19.1 & 1.15 & 18.1 & 1.09 \\
\hline $\begin{array}{l}\text { Filtration Total } \\
\text { Ion Exchange }\end{array}$ & 63.1 & 3.79 & 322 & 19.3 \\
Utilities & & & & \\
Electricity & $7.10 \mathrm{E}-02$ & $4.26 \mathrm{E}-03$ & $7.10 \mathrm{E}-02$ & $4.26 \mathrm{E}-03$ \\
Steam & 0.24 & $1.44 \mathrm{E}-02$ & 0.24 & $1.44 \mathrm{E}-02$ \\
\hline Total & 0.31 & $1.87 \mathrm{E}-02$ & 0.31 & $1.87 \mathrm{E}-02$ \\
Raw Materials & & & & \\
Filtered pyoil & 63.1 & 3.79 & 322 & 19.3 \\
Ethanol & 31.6 & 1.90 & 31.6 & 1.90 \\
Sulfuric Acid & 0.32 & $1.90 \mathrm{E}-02$ & 0.32 & $1.90 \mathrm{E}-02$ \\
NaOH & 4.26 & 0.26 & 4.26 & 0.26 \\
NaCl & 0.52 & $3.13 \mathrm{E}-02$ & 0.52 & $3.13 \mathrm{E}-02$ \\
Rinse water & $8.72 \mathrm{E}-04$ & $5.23 \mathrm{E}-05$ & $8.72 \mathrm{E}-04$ & $5.23 \mathrm{E}-05$ \\
\hline $\begin{array}{l}\text { Total } \\
\text { Waste Streams }\end{array}$ & 99.8 & 5.99 & 359 & 21.5 \\
Spent Brine & $2.47 \mathrm{E}-02$ & $1.48 \mathrm{E}-03$ & $2.47 \mathrm{E}-02$ & $1.48 \mathrm{E}-03$ \\
\hline $\begin{array}{l}\text { Stabilized PyOil } \\
\text { Total }\end{array}$ & 100 & 6.01 & 359 & 21.6 \\
Stabilized PyOil & & & & \\
(no / ethanol) & 69.2 & 1.61 & 357 & 8.30 \\
\hline
\end{tabular}


Table A6.20: CED for stabilized pyrolysis oil derived from waste wood using displacement allocation with a functional unit of one MJ of stabilized pyrolysis oil

\begin{tabular}{lc}
\hline Cumulative Energy Demand & MJ/MJ \\
\hline Non renewable fossil & $2.01 \mathrm{E}-02$ \\
Non renewable nuclear & $8.44 \mathrm{E}-02$ \\
Non renewable biomass & $3.51 \mathrm{E}-07$ \\
Renewable biomass & 1.99 \\
Renewable others & $3.98 \mathrm{E}-04$ \\
Renewable water & $7.82 \mathrm{E}-03$ \\
Total & 2.10 \\
\hline
\end{tabular}

Table A6.21: FED for stabilized pyrolysis oil derived from waste wood using displacement allocation with a functional unit of one MJ of stabilized pyrolysis oil

\begin{tabular}{lc}
\hline Fossil Energy Demand & MJ/MJ \\
\hline Electricity & 0.220 \\
Diesel & $4.47 \mathrm{E}-02$ \\
Truck Transport & $3.12 \mathrm{E}-02$ \\
Ethanol & $1.91 \mathrm{E}-02$ \\
Filter Cake & $-5.13 \mathrm{E}-02$ \\
Steam Credit & -0.252 \\
Remaining & $8.56 \mathrm{E}-03$ \\
Total & $2.01 \mathrm{E}-02$ \\
\hline
\end{tabular}


Table A6.22: GHG emissions for stabilized pyrolysis oil derived from wild algae using both displacement and energy allocation with two functional units of metric tons of stabilized pyrolysis oil and MJ of stabilized pyrolysis oil

\begin{tabular}{lcccc}
\hline \multicolumn{1}{c}{ Wild Algae } & $\begin{array}{c}\text { kg/MT } \\
\text { (Displacement) }\end{array}$ & $\begin{array}{c}\text { g/MJ } \\
\text { (Displacement) }\end{array}$ & $\begin{array}{c}\text { kg/MT } \\
\text { (Spatari et al.) }\end{array}$ & $\begin{array}{c}\text { g/MJ } \\
\text { (Spatari et al.) }\end{array}$ \\
\hline Pretreatment & & & & \\
Sizing \& Handling & 63.1 & 2.55 & 56.3 & 2.27 \\
\hline Total & 63.1 & 2.55 & 56.3 & 2.27 \\
Pyrolysis & & & & \\
Raw Materials & 1262 & 51.0 & 1126 & 45.5 \\
\hline Wild Algae & -964 & -38.9 & -859 & -34.7 \\
Wild Algae (WWT) & $1.01 \mathrm{E}-02$ & $4.08 \mathrm{E}-04$ & $9.01 \mathrm{E}-03$ & $3.64 \mathrm{E}-04$ \\
Sand & $8.12 \mathrm{E}-02$ & $3.28 \mathrm{E}-03$ & $7.24 \mathrm{E}-02$ & $2.93 \mathrm{E}-03$ \\
Sand Transport & 1263 & 51.0 & 1126 & 45.5 \\
\hline Total & -964 & -38.9 & -859 & -34.7 \\
Total (WWT) & & & & \\
RTP Utilities & $2.45 \mathrm{E}-02$ & $9.92 \mathrm{E}-04$ & $2.19 \mathrm{E}-02$ & $8.85 \mathrm{E}-04$ \\
\hline Natural Gas & 3.95 & 0.16 & 3.52 & 0.14 \\
Water & -57.7 & -2.33 & & \\
Steam & 0.40 & $1.63 \mathrm{E}-02$ & 0.36 & $1.46 \mathrm{E}-02$ \\
Air & 214 & 8.64 & 191 & 7.70 \\
Electricity & 160 & 6.49 & 195 & 7.86 \\
\hline Total & & & & \\
Waste Streams & 4.37 & 0.18 & 3.89 & 0.16 \\
\hline Ash to landfill & 4.37 & 0.18 & 3.89 & 0.16 \\
\hline Total & 1490 & 60.2 & 1380 & 55.8 \\
Pyrolysis Total & -736 & -29.7 & -604 & -24.4 \\
Pyrolysis Total & & & & \\
(WWT) & & & & \\
Filtration & & & & \\
\hline & & & & \\
\hline
\end{tabular}




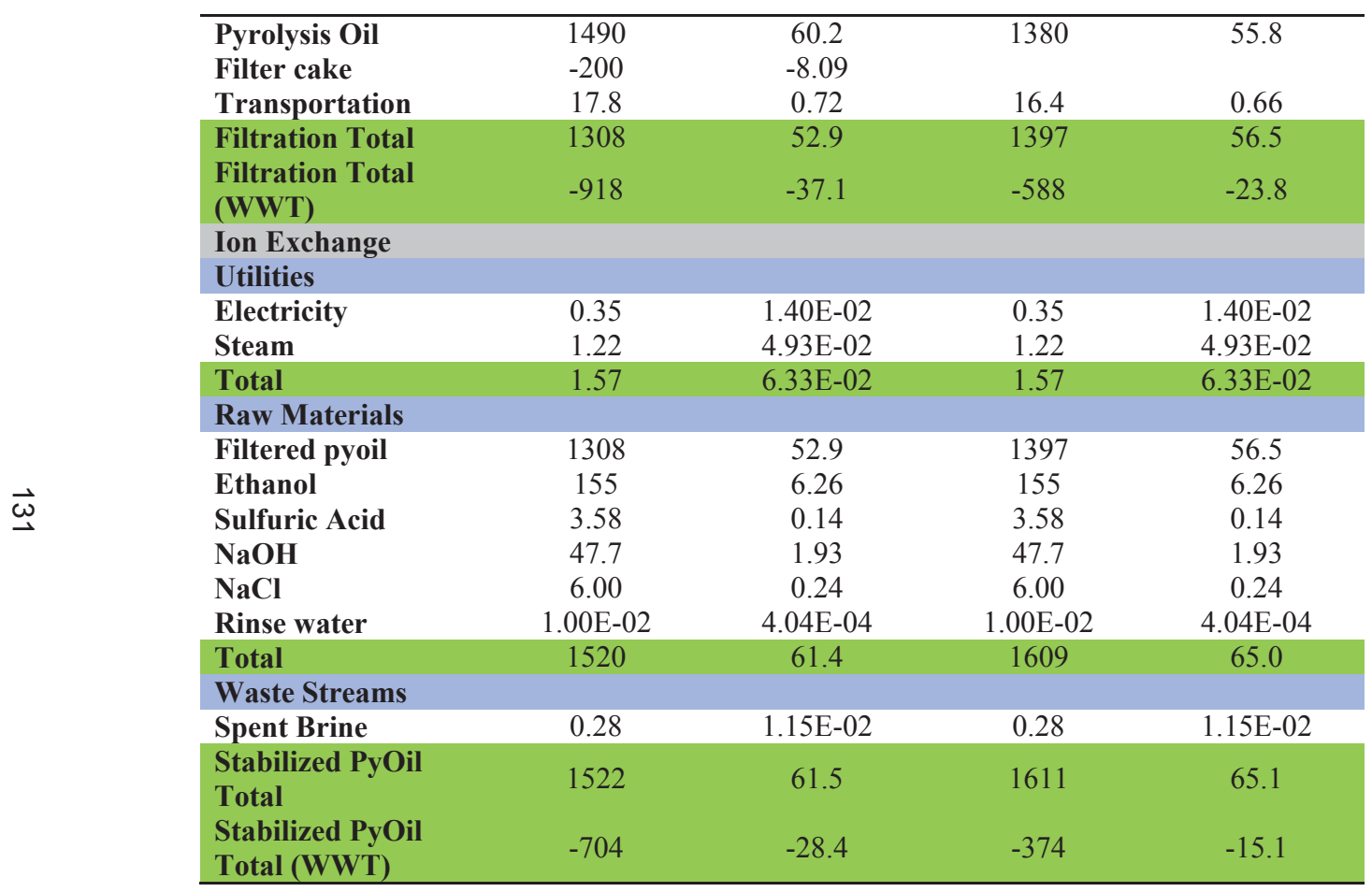


Table A6.23: CED for stabilized pyrolysis oil derived from wild using displacement allocation and no wastewater treatment credit with a functional unit of one MJ of stabilized pyrolysis oil

\begin{tabular}{lc}
\hline Cumulative Energy Demand & MJ/MJ \\
\hline Non renewable fossil & 0.932 \\
Non renewable nuclear & 0.260 \\
Non renewable biomass & $1.54 \mathrm{E}-06$ \\
Renewable biomass & 1.38 \\
Renewable others & $1.54 \mathrm{E}-03$ \\
Renewable water & $2.48 \mathrm{E}-02$ \\
Total & 2.60 \\
\hline
\end{tabular}

Table A6.24: FED for stabilized pyrolysis oil derived from wild using displacement allocation and no wastewater treatment credit with a functional unit of one MJ of stabilized pyrolysis oil

\begin{tabular}{lc}
\hline Fossil Energy & MJ/MJ \\
\hline Electricity & 0.591 \\
Chemical additives & 0.330 \\
Ethanol & $6.32 \mathrm{E}-02$ \\
Truck Transport & $3.34 \mathrm{E}-02$ \\
Filter Cake & $-7.76 \mathrm{E}-02$ \\
Steam Credit & $-3.81 \mathrm{E}-02$ \\
Remaining & $3.00 \mathrm{E}-02$ \\
Total & 0.932 \\
\hline
\end{tabular}


Table A6.25: GHG emissions for biofuel derived from sugarcane bagasse using both displacement and energy allocation with two functional units of metric tons of biofuel and MJ of biofuel

\begin{tabular}{lcccc}
\hline \multicolumn{1}{c}{ Bagasse Results } & $\begin{array}{c}\text { kg/MT } \\
\text { (Displacement }\end{array}$ & $\begin{array}{c}\text { g/MJ } \\
\text { (Displacement) }\end{array}$ & $\begin{array}{c}\text { kg } / \mathbf{M T} \\
\text { (Spatari et } \\
\text { al.) }\end{array}$ & $\begin{array}{c}\text { g/MJ } \\
\text { (Spatari et } \\
\text { al.) }\end{array}$ \\
\hline $\begin{array}{l}\text { Feedstock } \\
\text { Production }\end{array}$ & 66.4 & 1.55 & 50.6 & 1.18 \\
$\begin{array}{l}\text { Pyrolysis } \\
\text { Stabilization }\end{array}$ & 232 & 5.41 & 377 & 8.77 \\
Upgrading & -19.3 & -0.45 & 133 & 3.10 \\
Raw Material & & & & \\
Stabilized pyoil & & & & \\
Effluents & 280 & 6.50 & 561 & 13.1 \\
Waste water & 0.32 & $7.53 \mathrm{E}-03$ & 0.28 & $6.40 \mathrm{E}-03$ \\
Utilities & & & & \\
Electricity & 134 & 3.12 & 114 & 2.65 \\
$\begin{array}{l}\text { Natural Gas } \\
\text { Water }\end{array}$ & 75.2 & 1.75 & 63.9 & 1.49 \\
$\begin{array}{l}\text { Steam } \\
\text { Solid waste }\end{array}$ & 0.47 & $1.09 \mathrm{E}-02$ & 0.40 & $9.23 \mathrm{E}-03$ \\
$\begin{array}{l}\text { Integrated H2 Plant } \\
\text { Natural Gas }\end{array}$ & -150 & -3.49 & & \\
$\begin{array}{l}\text { Demin. Water } \\
\text { HP Steam }\end{array}$ & $8.21 \mathrm{E}-03$ & $1.91 \mathrm{E}-04$ & $6.97 \mathrm{E}-03$ & $1.62 \mathrm{E}-04$ \\
$\begin{array}{l}\text { Electricity } \\
\text { Transportation }\end{array}$ & 482 & & & \\
Overall Total & $6.87 \mathrm{E}-02$ & $1.60 \mathrm{E}-03$ & $5.84 \mathrm{E}-02$ & $1.36 \mathrm{E}-03$ \\
\hline & -408 & -9.49 & & \\
\hline & 38.1 & 0.89 & 32.4 & 0.75 \\
\hline & 8.86 & 0.21 & 7.53 & 0.18 \\
\hline
\end{tabular}


Table A6.26: CED for biofuel derived from sugarcane bagasse using displacement allocation with a functional unit of one $\mathrm{MJ}$ of biofuel

\begin{tabular}{lc}
\hline Cumulative Energy Demand & MJ/MJ \\
\hline Non renewable fossil & 0.118 \\
Non renewable nuclear & $7.62 \mathrm{E}-02$ \\
Non renewable biomass & $4.96 \mathrm{E}-07$ \\
Renewable biomass & 1.05 \\
Renewable others & $4.49 \mathrm{E}-04$ \\
Renewable water & $7.45 \mathrm{E}-03$ \\
Total & 1.25 \\
\hline
\end{tabular}

Table A6.27: FED for biofuel derived from sugarcane bagasse using displacement allocation with a functional unit of one $\mathrm{MJ}$ of biofuel

\begin{tabular}{lc}
\hline Fossil Energy & MJ/MJ \\
\hline Natural Gas & 0.224 \\
Electricity & 0.18 \\
Truck transport & $3.81 \mathrm{E}-02$ \\
Ethanol & $1.92 \mathrm{E}-02$ \\
Filter Cake & $-3.96 \mathrm{E}-02$ \\
Steam Credit & -0.319 \\
Remaining & $1.57 \mathrm{E}-02$ \\
Total & 0.118 \\
\hline
\end{tabular}


Table A6.28: GHG emissions for biofuel derived from guinea grass using both displacement and energy allocation with two functional units of metric tons of biofuel and MJ of biofuel

\begin{tabular}{|c|c|c|c|c|c|}
\hline & Guinea Grass Results & $\begin{array}{c}\text { kg /MT } \\
\text { (Displacement) }\end{array}$ & $\begin{array}{c}\text { g/MJ } \\
\text { (Displacement) }\end{array}$ & $\begin{array}{c}\text { kg /MT } \\
\text { (Spatari } \\
\text { et al.) } \\
\end{array}$ & $\begin{array}{c}\text { g/MJ } \\
\text { (Spatari et } \\
\text { al.) } \\
\end{array}$ \\
\hline & $\begin{array}{l}\text { Feedstock } \\
\text { Production }\end{array}$ & 605 & 14.1 & 461 & 10.7 \\
\hline & Pyrolysis & 522 & 12.1 & 472 & 11.0 \\
\hline & Stabilization & 180 & 4.19 & 326 & 7.57 \\
\hline & Upgrading & & & & \\
\hline & Raw Material & & & & \\
\hline & Stabilized pyoil & 1306 & 30.4 & 1259 & 29.3 \\
\hline & Effluents & & & & \\
\hline & Waste water & 0.44 & $1.01 \mathrm{E}-02$ & 0.36 & 8.33E-03 \\
\hline & Utilities & & & & \\
\hline & Electricity & 158 & 3.67 & 130 & 3.02 \\
\hline & Natural Gas & 88.8 & 2.07 & 72.9 & 1.70 \\
\hline & Water & 0.55 & $1.28 \mathrm{E}-02$ & 0.45 & $1.05 \mathrm{E}-02$ \\
\hline & Steam & -176 & -4.09 & & \\
\hline & Solid waste & $9.74 \mathrm{E}-03$ & $2.27 \mathrm{E}-04$ & 8.00E-03 & $1.86 \mathrm{E}-04$ \\
\hline & Integrated $\mathrm{H}_{2}$ Plant & & & & \\
\hline & Natural Gas & 599 & 13.9 & 492 & 11.4 \\
\hline & Demin. Water & $8.52 \mathrm{E}-02$ & $1.98 \mathrm{E}-03$ & $7.00 \mathrm{E}-02$ & $1.63 \mathrm{E}-03$ \\
\hline & HP Steam & -509 & -11.8 & & \\
\hline & Electricity & 47.4 & 1.10 & 38.9 & 0.91 \\
\hline & Transportation & 8.86 & 0.21 & 7.3 & 0.17 \\
\hline & Overall Total & 1525 & 35.5 & 2001 & 46.5 \\
\hline
\end{tabular}


Table A6.29: CED for biofuel derived from guinea grass using displacement allocation with a functional unit of one MJ of biofuel

\begin{tabular}{lc}
\hline Cumulative Energy Demand & MJ/MJ \\
\hline Non renewable fossil & 0.388 \\
Non renewable nuclear & 0.113 \\
Non renewable biomass & $1.48 \mathrm{E}-06$ \\
Renewable biomass & 1.67 \\
Renewable others & $8.63 \mathrm{E}-04$ \\
Renewable water & $1.22 \mathrm{E}-02$ \\
Total & 2.18 \\
\hline
\end{tabular}

Table A6.30: FED for biofuel derived from guinea grass using displacement allocation with a functional unit of one MJ of biofuel

$\vec{\omega}$

\begin{tabular}{lc}
\hline Fossil Energy Demand & MJ/MJ \\
\hline Natural Gas & 0.276 \\
Electricity & 0.22 \\
Ethanol & $5.91 \mathrm{E}-02$ \\
Urea & $4.44 \mathrm{E}-02$ \\
Truck transport & $4.32 \mathrm{E}-02$ \\
Filter Cake & $-4.87 \mathrm{E}-02$ \\
Steam Credit & -0.303 \\
Remaining & $9.67 \mathrm{E}-02$ \\
Total & 0.388 \\
\hline
\end{tabular}


Table A6.31: GHG emissions for biofuel derived from open pond algae using both displacement and energy allocation with two functional units of metric tons of biofuel and MJ of biofuel

\begin{tabular}{|c|c|c|c|c|c|}
\hline \multirow{24}{*}{$\underline{\omega}_{\vec{v}}$} & Open Pond Algae & $\begin{array}{c}\text { kg /MT } \\
\text { (Displacement) }\end{array}$ & $\begin{array}{c}\text { g/MJ } \\
\text { (Displacement) }\end{array}$ & $\begin{array}{c}\text { kg /MT } \\
\text { (Spatari et } \\
\text { al.) } \\
\end{array}$ & $\begin{array}{c}\text { g/MJ } \\
\text { (Spatari et } \\
\text { al.) } \\
\end{array}$ \\
\hline & Feedstock Production & 1307 & 30.4 & 940 & 21.9 \\
\hline & $\begin{array}{l}\text { Feedstock Production } \\
\text { (nutrient recycle) }\end{array}$ & 1052 & 24.5 & 751 & 17.5 \\
\hline & Pyrolysis & 192 & 4.47 & 411 & 9.56 \\
\hline & Stabilization & -79.4 & -1.85 & 144 & 3.35 \\
\hline & Upgrading & & & & \\
\hline & Raw Material & & & & \\
\hline & Stabilized pyoil & 1420 & 33.0 & 1495 & 34.8 \\
\hline & Effluents & & & & \\
\hline & Waste water & 0.18 & 0.00 & 0.15 & $3.47 \mathrm{E}-03$ \\
\hline & Utilities & & & & \\
\hline & Electricity & 121 & 2.81 & 103 & 2.40 \\
\hline & Natural Gas & 67.9 & 1.58 & 57.9 & 1.35 \\
\hline & Water & 0.42 & $9.81 \mathrm{E}-03$ & 0.36 & 8.37E-03 \\
\hline & Steam & -136 & -3.16 & & \\
\hline & Solid waste & $7.45 \mathrm{E}-03$ & $1.73 \mathrm{E}-04$ & $6.35 \mathrm{E}-03$ & $1.48 \mathrm{E}-04$ \\
\hline & Integrated $\mathrm{H}_{2}$ Plant & & & & \\
\hline & Natural Gas & 442 & 10.3 & 377 & 8.77 \\
\hline & Demin. Water & $6.84 \mathrm{E}-02$ & $1.59 \mathrm{E}-03$ & $5.83 \mathrm{E}-02$ & $1.36 \mathrm{E}-03$ \\
\hline & HP Steam & -408 & -9.49 & & \\
\hline & Electricity & 38.1 & 0.89 & 32.5 & 0.76 \\
\hline & Transportation & 8.86 & 0.21 & 7.56 & 0.18 \\
\hline & Overall Total & 1554 & 36.2 & 2074 & 48.2 \\
\hline & Overall Total (nutrient & 1300 & 30.2 & 1885 & 43.8 \\
\hline
\end{tabular}




\section{recycle)}

Table A6.32: CED for biofuel derived from open pond algae using displacement allocation with a functional unit of one MJ of biofuel

\begin{tabular}{lc}
\hline Cumulative Energy Demand & MJ/MJ \\
\hline Non renewable fossil & 0.596 \\
Non renewable nuclear & 0.2 \\
Non renewable biomass & $3.58 \mathrm{E}-05$ \\
Renewable biomass & 1.44 \\
Renewable others & $1.51 \mathrm{E}-03$ \\
Renewable water & $2.12 \mathrm{E}-02$ \\
Total & 2.26 \\
\hline
\end{tabular}

$\vec{\infty} \quad$ Table A6.33: FED for biofuel derived from open pond algae using displacement allocation with a functional unit of one MJ of biofuel

\begin{tabular}{lc}
\hline Fossil Energy Demand & MJ/MJ \\
\hline Electricity & 0.228 \\
Natural Gas & 0.204 \\
Ammonium nitrate & 0.201 \\
Electricity & 0.191 \\
Phosphate & $6.9 \mathrm{E}-02$ \\
Potassium & $4.36 \mathrm{E}-02$ \\
Filter Cake & $-5.59 \mathrm{E}-02$ \\
Steam Credit & -0.352 \\
Remaining & $6.67 \mathrm{E}-02$ \\
Total & 0.596 \\
\hline
\end{tabular}


Table A6.34: GHG emissions for biofuel derived from corn stover using both displacement and energy allocation with two functional units of metric tons of biofuel and $\mathrm{MJ}$ of biofuel

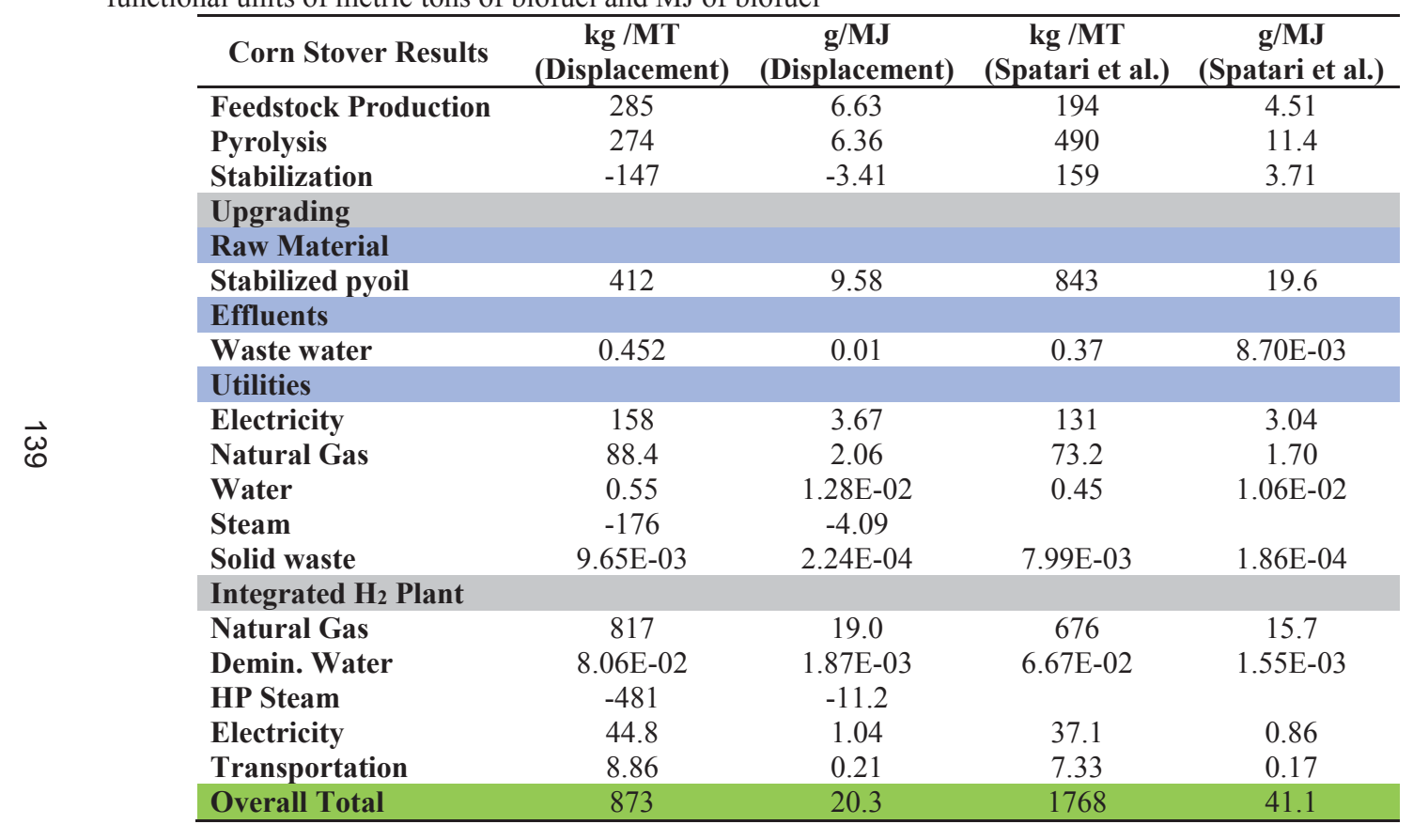


Table A6.35: Comparison of literature (Kauffman et al. 2011) GHG emission to MTU/UOP GHG emissions

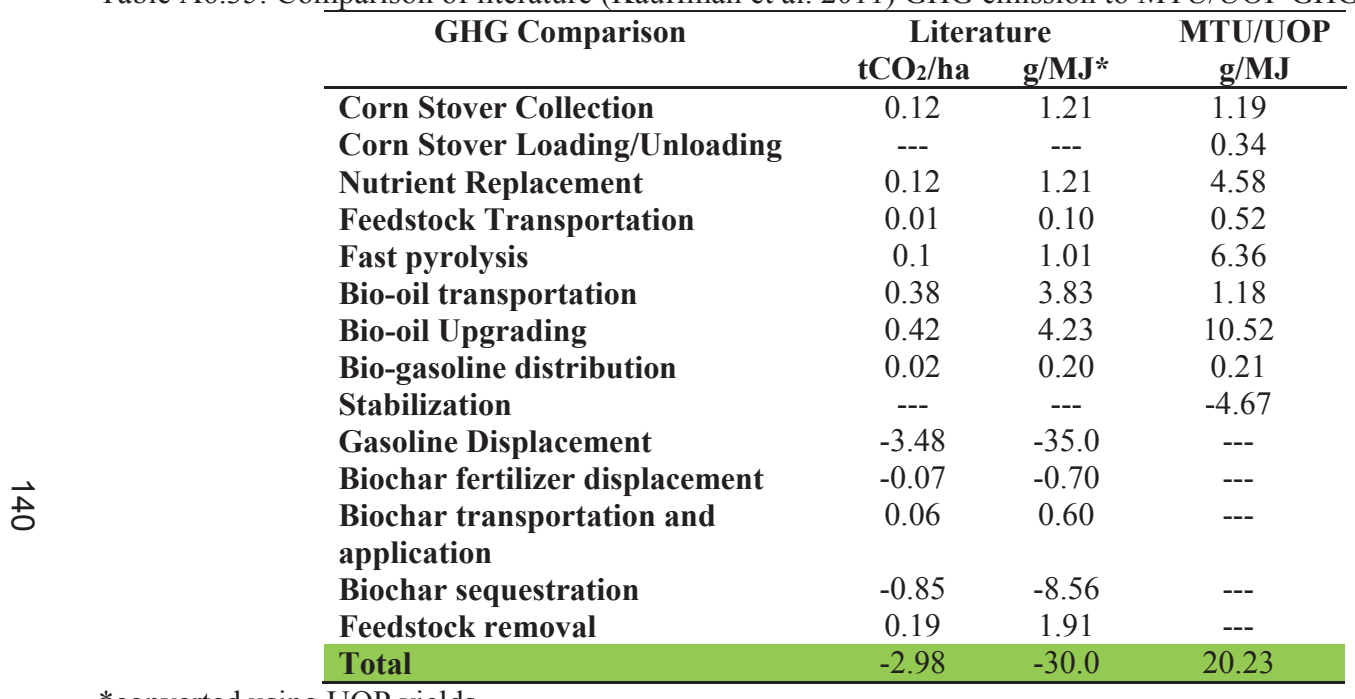

* converted using UOP yields 
Table A6.36: CED for biofuel derived from corn stover using displacement allocation with a functional unit of one MJ of biofuel

\begin{tabular}{lc}
\hline Cumulative Energy Demand & MJ/MJ \\
\hline Non renewable fossil & 0.271 \\
Non renewable nuclear & 0.108 \\
Non renewable biomass & $6.32 \mathrm{E}-06$ \\
Renewable biomass & 1.85 \\
Renewable others & $6.92 \mathrm{E}-04$ \\
Renewable water & $1.08 \mathrm{E}-02$ \\
Total & 2.24 \\
\hline
\end{tabular}

Table A6.37: FED for biofuel derived from corn stover using displacement allocation with a functional unit of one MJ of biofuel

\begin{tabular}{lc}
\hline Fossil Energy Demand & MJ/MJ \\
\hline Natural Gas & 0.363 \\
Electricity & 0.247 \\
Truck transport & $1.87 \mathrm{E}-02$ \\
Fertilizer & $7.03 \mathrm{E}-02$ \\
Ethanol & $2.42 \mathrm{E}-02$ \\
Filter Cake & $-7.64 \mathrm{E}-02$ \\
Steam Credit & -0.429 \\
Remaining & $5.29 \mathrm{E}-02$ \\
Total & 0.271 \\
\hline
\end{tabular}


Table A6.38: GHG emissions for biofuel derived from low ash corn stover using both displacement and energy allocation with two functional units of metric tons of biofuel and MJ of biofuel

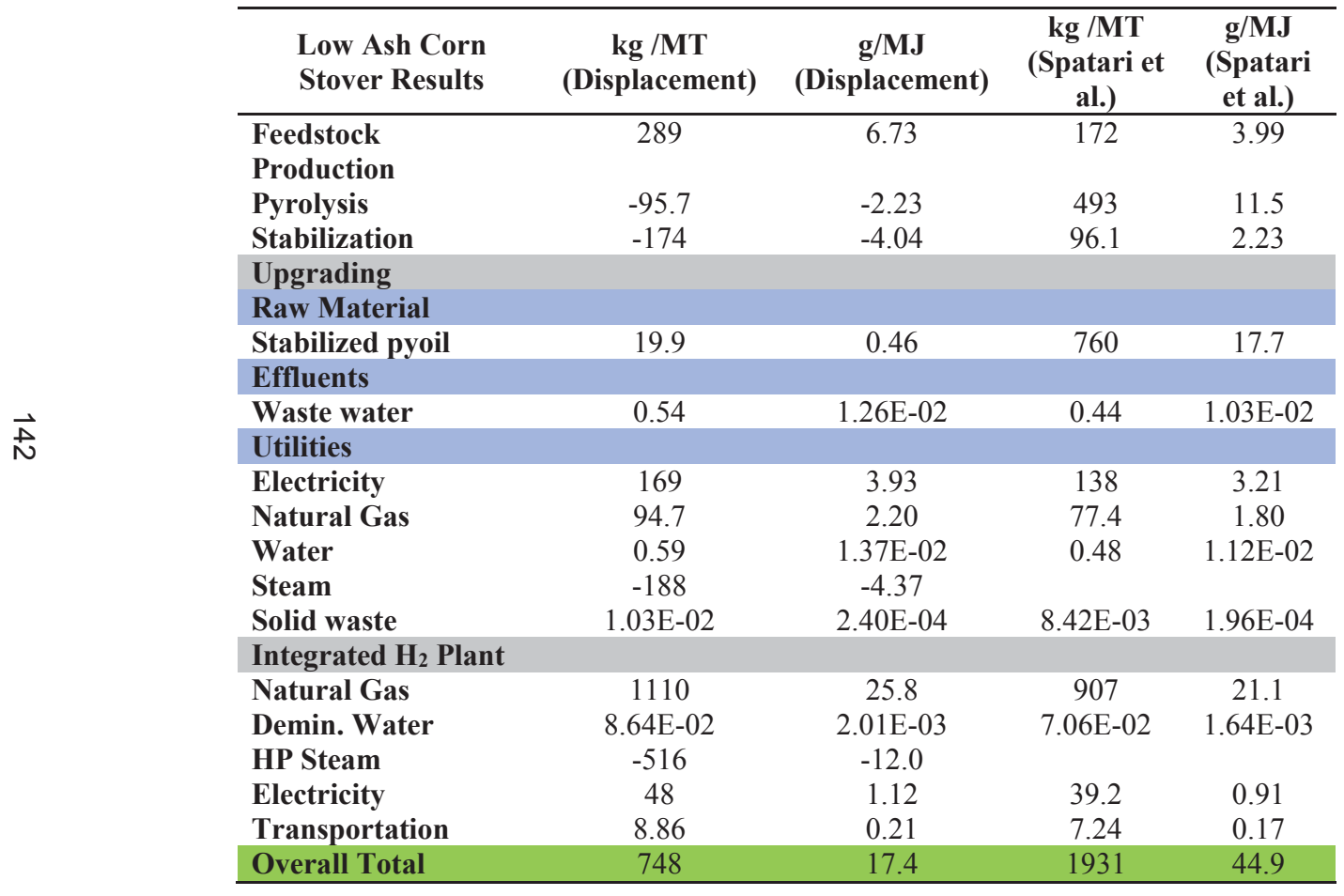


Table A6.39: CED for biofuel derived from low ash corn stover using displacement allocation with a functional unit of one $\mathrm{MJ}$ of biofuel

\begin{tabular}{lc}
\hline Cumulative Energy Demand & MJ/MJ \\
\hline Non renewable fossil & 0.215 \\
Non renewable nuclear & 0.115 \\
Non renewable biomass & $6.02 \mathrm{E}-06$ \\
Renewable biomass & 1.84 \\
Renewable others & $6.62 \mathrm{E}-04$ \\
Renewable water & $1.12 \mathrm{E}-02$ \\
Total & 2.14 \\
\hline
\end{tabular}

Table A6.40: FED for biofuel derived from low ash corn stover using displacement allocation with a functional unit of one $\mathrm{MJ}$ of biofuel

\begin{tabular}{lc}
\hline Fossil Energy Demand & MJ/MJ \\
\hline Natural Gas & 0.363 \\
Electricity & 0.246 \\
Ammonia & $4.12 \mathrm{E}-02$ \\
Diesel & $2.98 \mathrm{E}-02$ \\
Potassium & $2.94 \mathrm{E}-02$ \\
Truck transport & $2.89 \mathrm{E}-02$ \\
Ethanol & $2.42 \mathrm{E}-02$ \\
Filter Cake & $-7.63 \mathrm{E}-02$ \\
Steam Credit & -0.428 \\
Remaining & $4.07 \mathrm{E}-02$ \\
Total & 0.215 \\
\hline
\end{tabular}


Table A6.41: GHG emissions for biofuel derived from switchgrass using both displacement and energy allocation with two functional units of metric tons of biofuel and $\mathrm{MJ}$ of biofuel

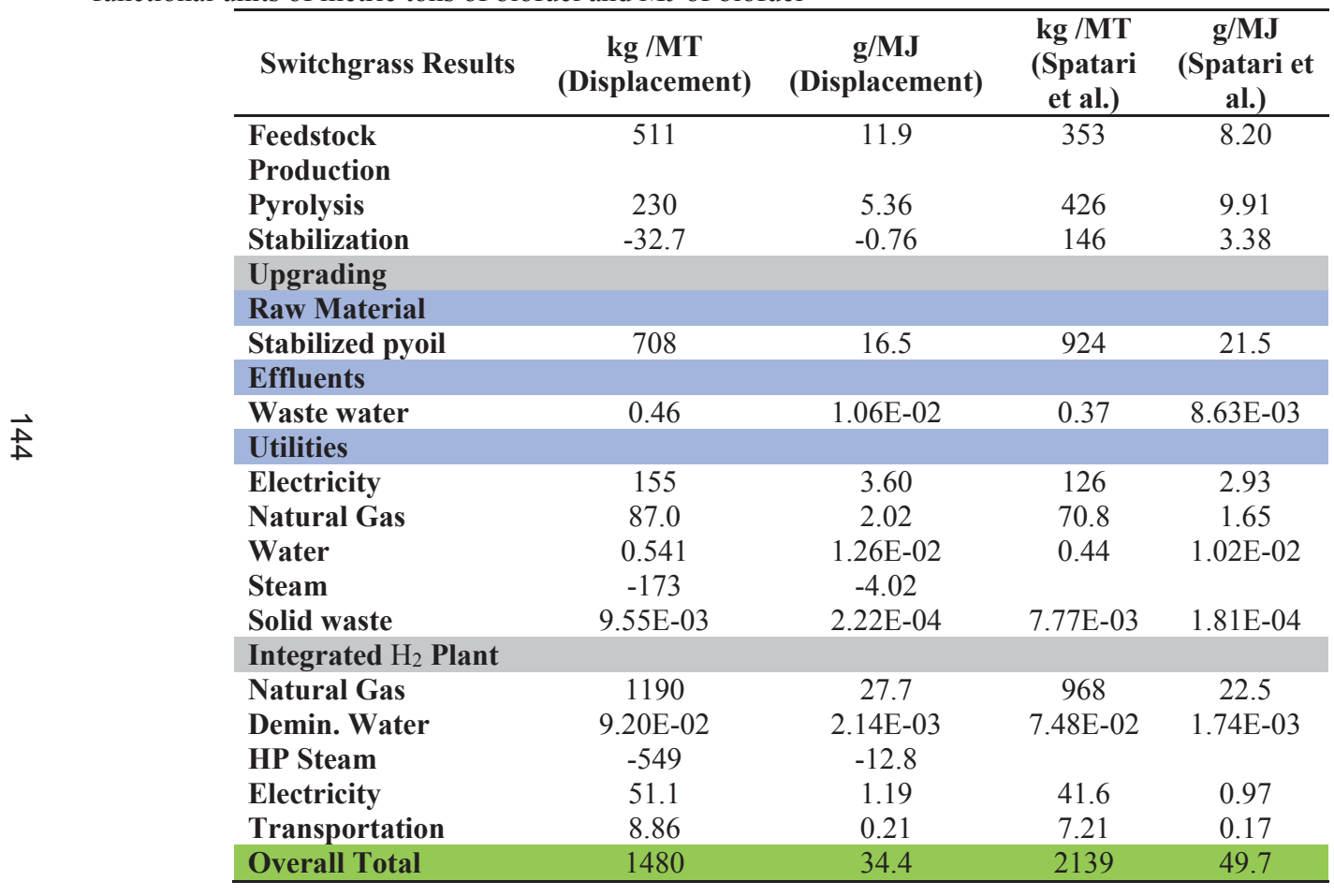


Table A6.42: CED for biofuel derived from switchgrass using displacement allocation with a functional unit of one MJ of biofuel

\begin{tabular}{lc}
\hline Cumulative Energy Demand & MJ/MJ \\
\hline Non renewable fossil & 0.426 \\
Non renewable nuclear & 0.104 \\
Non renewable biomass & $1.09 \mathrm{E}-05$ \\
Renewable biomass & 1.48 \\
Renewable others & $7.14 \mathrm{E}-04$ \\
Renewable water & $1.15 \mathrm{E}-02$ \\
Total & 2.03 \\
\hline
\end{tabular}

Table A6.43: FED for biofuel derived from switchgrass using displacement allocation with a functional unit of one MJ of biofuel

\begin{tabular}{lc}
\hline Fossil Energy & MJ/MJ \\
\hline Natural Gas & 0.514 \\
Electricity & 0.221 \\
Diesel & $4.58 \mathrm{E}-02$ \\
Truck transport & $3.12 \mathrm{E}-02$ \\
Ethanol & $2.23 \mathrm{E}-02$ \\
Filter Cake & $-4.77 \mathrm{E}-02$ \\
Steam Credit & -0.43 \\
Remaining & $6.92 \mathrm{E}-02$ \\
Total & 0.426 \\
\hline
\end{tabular}


Table A6.44: GHG emissions for biofuel derived from waste wood using both displacement and energy allocation with two functional units of metric tons of biofuel and $\mathrm{MJ}$ of biofuel

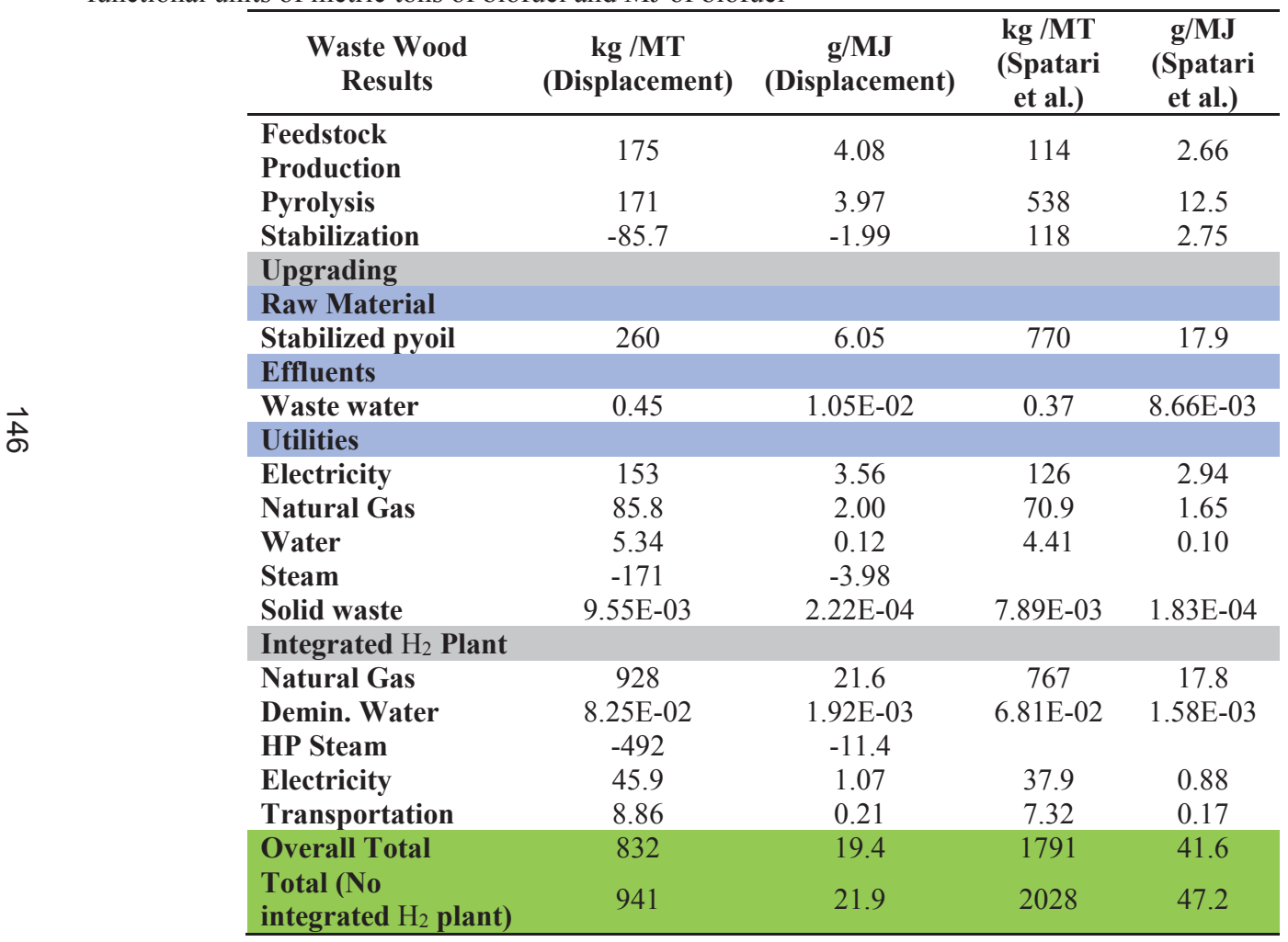




\begin{tabular}{|c|c|c|c|c|}
\hline Total (no ethanol) & 892 & 20.8 & 1818 & 42.3 \\
\hline $\begin{array}{l}\text { Total (no ethanol, } \\
\text { no integrated } \mathrm{H}_{2} \\
\text { plant) }\end{array}$ & 925 & 21.5 & 1993 & 46.4 \\
\hline
\end{tabular}

Table A6.45: CED for biofuel derived from waste wood using displacement allocation with a functional unit of one MJ of biofuel

\begin{tabular}{lc}
\hline Cumulative Energy Demand & MJ/MJ \\
\hline Non renewable fossil & 0.227 \\
Non renewable nuclear & 0.111 \\
Non renewable biomass & $5.24 \mathrm{E}-07$ \\
Renewable biomass & 2.00 \\
Renewable others & $6.02 \mathrm{E}-04$ \\
Renewable water & $1.06 \mathrm{E}-02$ \\
Total & 2.35 \\
\hline
\end{tabular}


Table A6.46: FED for biofuel derived from waste wood using displacement allocation with a functional unit of one MJ of biofuel

\begin{tabular}{lc}
\hline Fossil Energy & MJ/MJ \\
\hline Natural Gas & 0.407 \\
Electricity & 0.275 \\
Diesel & $4.5 \mathrm{E}-02$ \\
Truck transport & $3.13 \mathrm{E}-02$ \\
Ethanol & $1.92 \mathrm{E}-02$ \\
Filter Cake & $-5.16 \mathrm{E}-02$ \\
Steam Credit & -0.511 \\
Remaining & $1.27 \mathrm{E}-02$ \\
Total & 0.227 \\
\hline
\end{tabular}


Table A6.47: GHG emissions for biofuel derived from wild algae using both displacement and energy allocation with two functional units of metric tons of biofuel and $\mathrm{MJ}$ of biofuel

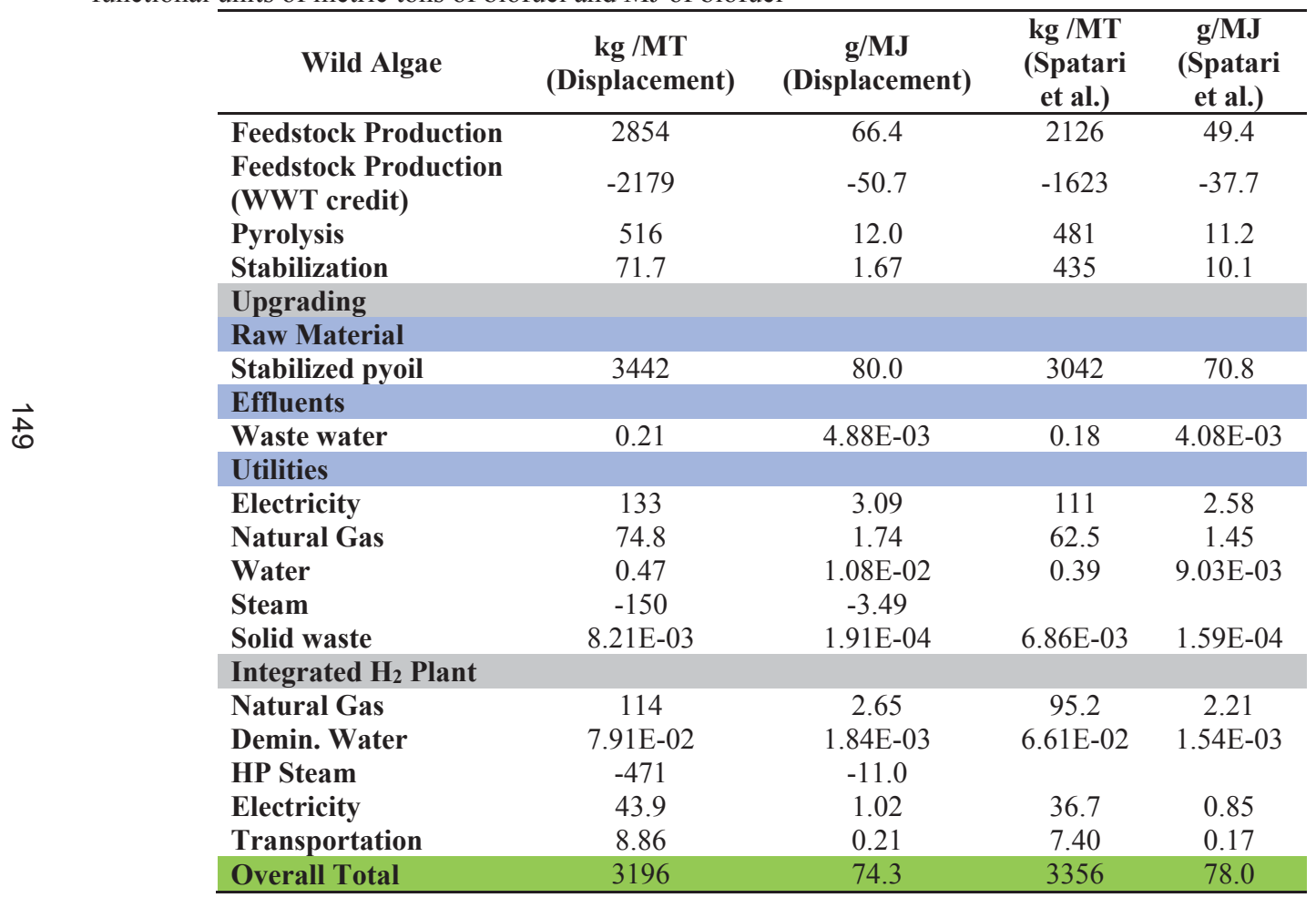




\begin{tabular}{lllll}
\hline $\begin{array}{l}\text { Overall Total (WWT } \\
\text { Credit) }\end{array}$ & -1837 & -42.7 & -393 & -9.13 \\
\hline
\end{tabular}

Table A6.48: CED for biofuel derived from wild algae using displacement allocation with a functional unit of one MJ of biofuel

\begin{tabular}{lc}
\hline Cumulative Energy Demand & MJ/MJ \\
\hline Non renewable fossil & 1.1 \\
Non renewable nuclear & 0.355 \\
Non renewable biomass & $1.91 \mathrm{E}-06$ \\
Renewable biomass & 1.79 \\
Renewable others & $2.08 \mathrm{E}-03$ \\
Renewable water & $3.37 \mathrm{E}-02$ \\
Total & 3.28 \\
\hline
\end{tabular}

$\overrightarrow{\text { ज़ }}$

Table A6.49: FED for biofuel derived from wild algae using displacement allocation with a functional unit of one MJ of biofuel

\begin{tabular}{lc}
\hline Fossil Energy Demand & MJ/MJ \\
\hline Electricity & 0.817 \\
Nutrients & 0.429 \\
Ethanol & $8.22 \mathrm{E}-02$ \\
Natural Gas & $7.57 \mathrm{E}-02$ \\
Filter Cake & -0.101 \\
Steam Credit & -0.291 \\
Remaining & $8.54 \mathrm{E}-02$ \\
Total & 1.1 \\
\hline
\end{tabular}

